\title{
Simulated Response of the High Plains Aquifer to Ground-Water Withdrawals in the Upper Republican Natural Resources District, Nebraska
}

By JON M. PECKENPAUGH, RICH A. KERN, JACK T. DUGAN, and JOHN M. KILPATRICK

U.S. GEOLOGICAL SURVEY

Water-Resources Investigations Report 95-4014

Prepared in cooperation with the

UPPER REPUBLICAN NATURAL RESOURCES DISTRICT and the NEBRASKA NATURAL RESOURCES COMMISSION 


\title{
U.S. DEPARTMENT OF THE INTERIOR \\ BRUCE BABBITT, Secretary
}

\author{
U.S. GEOLOGICAL SURVEY
}

GORDON P. EATON, Director

For additional information write to:

Copies of this report can be purchased from:

U.S. Geological Survey

District Chief

Earth Science Information Center

U.S. Geological Survey

Open-File Reports Section

Room 406, Federal Building

Box 25286, MS 517

100 Centennial Mall North

Denver Federal Center

Lincoln, Nebraska 68508

Denver, Colorado 80225 


\section{CONTENTS}

Abstract.1.1.

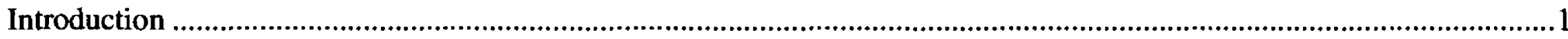

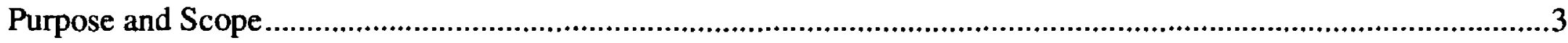

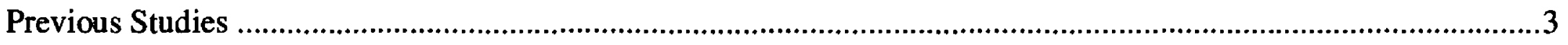

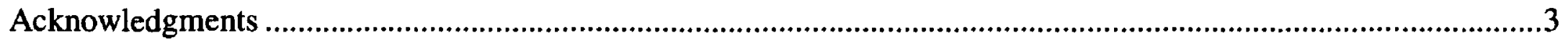

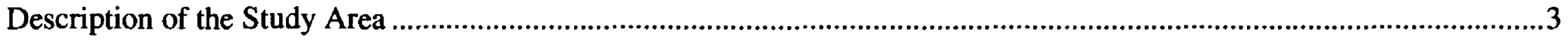

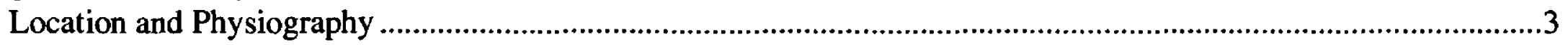

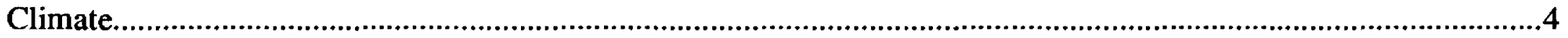

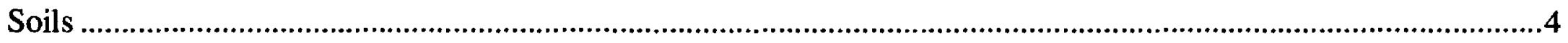

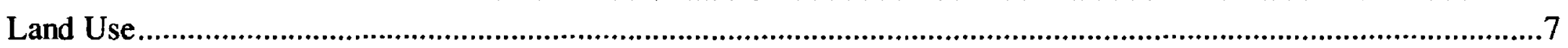

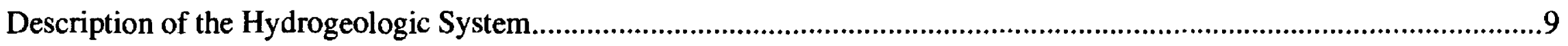

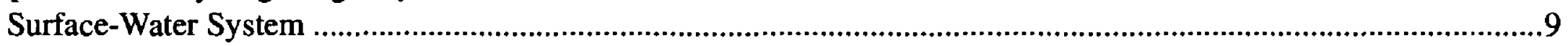

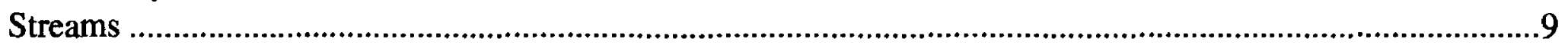

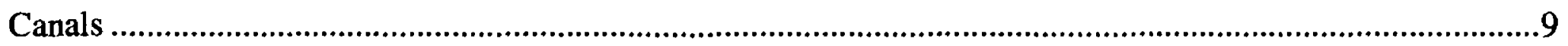

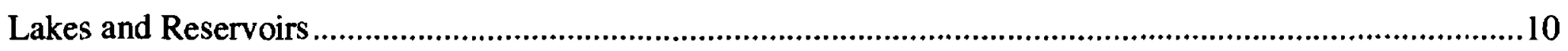

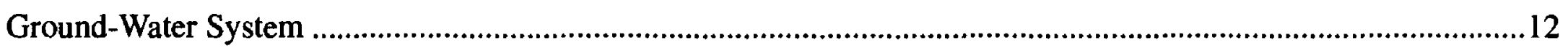

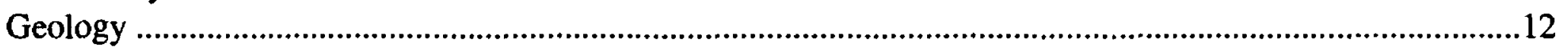

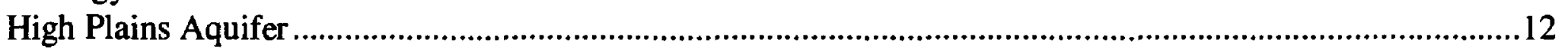

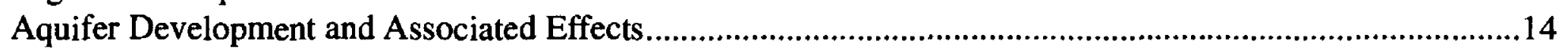

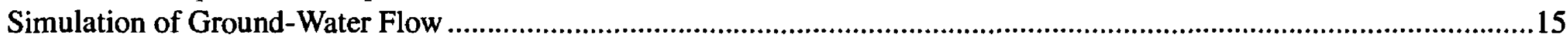

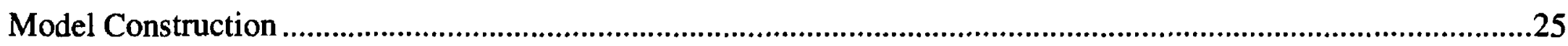

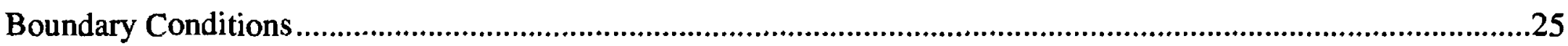

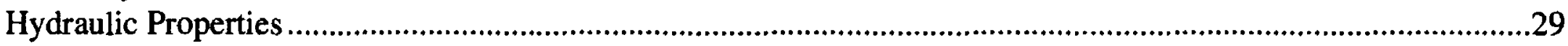

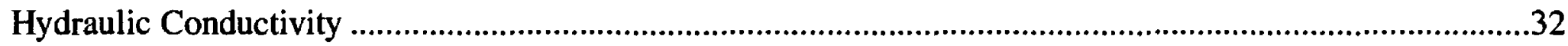

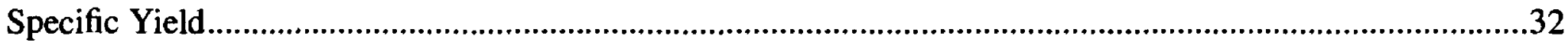

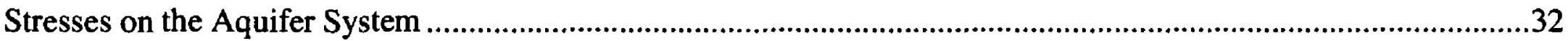

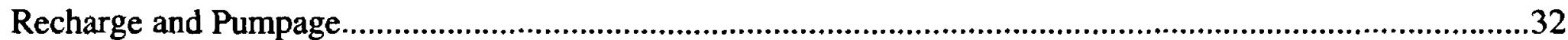

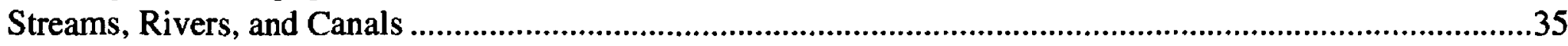

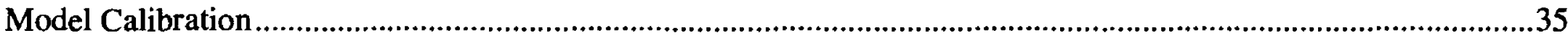

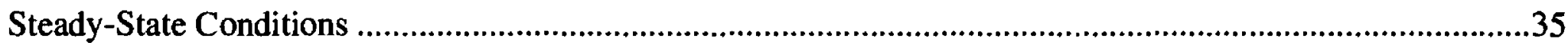

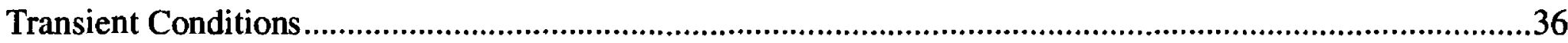

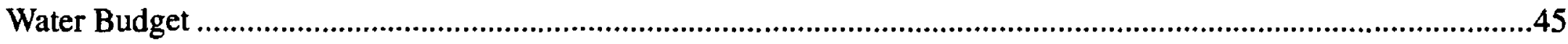

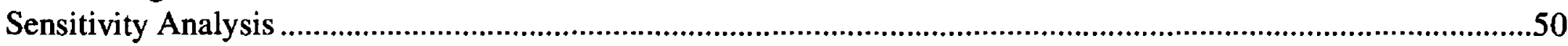

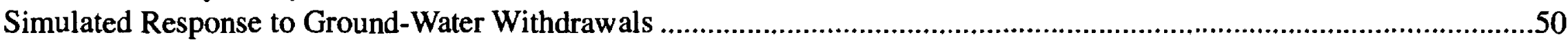

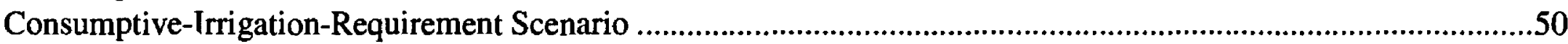

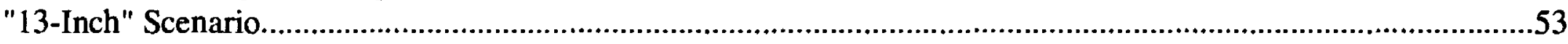

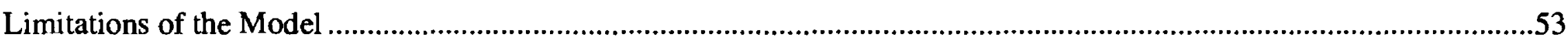

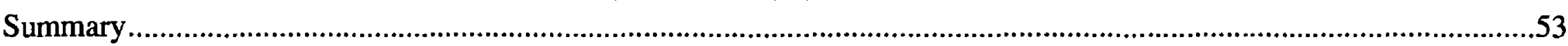

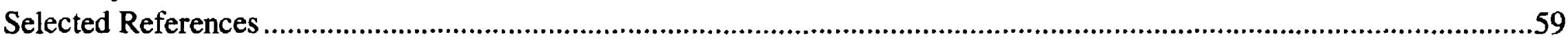

\section{FIGURES}

1-3. Map showing:

1. Location of study area and Upper Republican Natural Resources District..........................................................2

2. Average annual precipitation, $1951-89$, and location of selected weather stations ..............................................5

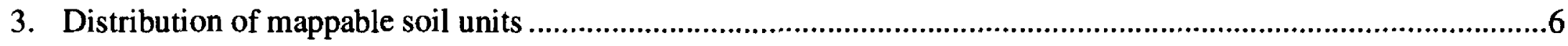

4. Schematic diagram of the surface-water system in the study area ..........................................................................10

5. Geologic section $B-B^{\prime}$, modified from Lappala (1978) .......................................................................................15 
6-25. Map showing:

6. Lateral extent of the Ogallala Formation and trace of geologic section $B-B^{\prime}$ from Lappala (1978)

7. Water-table altitude in the High Plains aquifer, spring 1989

8. Altitude of the base of the High Plains aquifer.

9. Location of registered wells in the Nebraska part of the study area drilled before 1952 .................................. 19

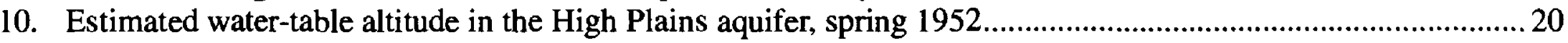

11. Location of registered wells in the Nebraska part of the study area drilled before 1975 ..................................21

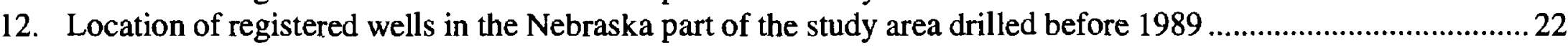

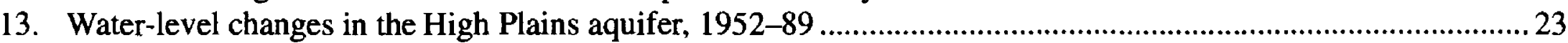

14. Perennial reaches of streams in 1975 and 1989 and location of seepage-measurement sites and streamflowgaging stations

15. Finite-difference grid used in modeling ground-water flow in study area ..........................................................2

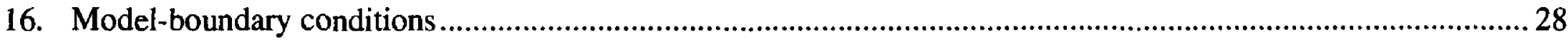

17. Location of test holes and irrigation wells from which data were used to estimate aquifer properties.................. 30

18. Distribution of hydraulic conductivity in the High Plains aquifer......................................................................33

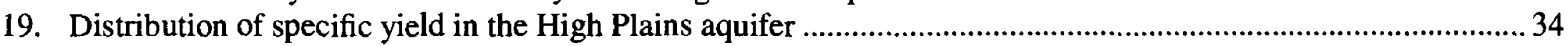

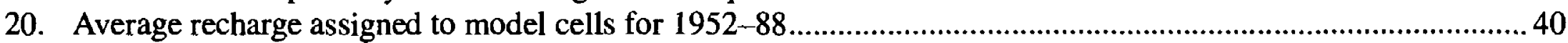

21. Pumpage assigned to cells for the June-August 1988 stress period ....................................................................... 41

22. Cells used to simulate interior streams and rivers using the stream-routing package ........................................ 42

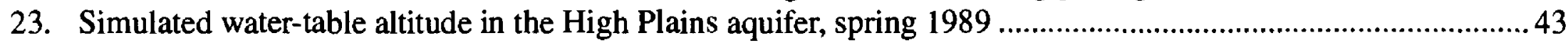

24. Difference between simulated and observed spring 1989 water-table altitudes in the High Plains aquifer...........44

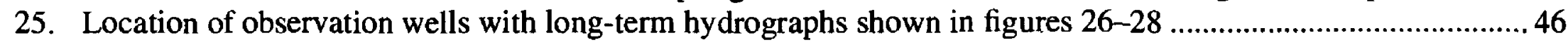

26. Hydrographs showing measured, simulated, and projected water levels for observation wells 2N-38W-10DD and $4 \mathrm{~N}-38 \mathrm{~W}-30 \mathrm{BCC}$.

27. Hydrographs showing measured, simulated, and projected water levels for observation wells $5 \mathrm{~N}-41 \mathrm{~W}-19 \mathrm{CBD}$ and $7 \mathrm{~N}-40 \mathrm{~W}-28 \mathrm{BBB}$

28. Hydrographs showing measured, simulated, and projected water levels for observation wells $10 \mathrm{~N}-36 \mathrm{~W}-13 \mathrm{BACC}$ and 11N-39W-35DDD

29-34. Map showing:

29. Projected water-level changes in the High Plains aquifer, 1989-2010, using consumptive-irrigationrequirement pumping scenario.

30. Projected water-level changes in the High Plains aquifer, 1989-2030, using consumptive-irrigationrequirement pumping scenario.

31. Projected saturated thickness of the High Plains aquifer in 2030 using consumptive-irrigation-requirement pumping scenario.

32. Projected water-level changes in the High Plains aquifer, 1989-2010, using 13-inch pumping scenario ............. 56

33. Projected water-level changes in the High Plains aquifer, 1989-2030, using 13-inch pumping scenario .............57

34. Projected saturated thickness of the High Plains aquifer in 2030 using 13-inch pumping scenario ......................58

\section{TABLES}

1. Mappable soil units in the study area and their hydrologic characteristics.....

2. Selected crops harvested in Chase, Dundy, and Perkins Counties, Nebraska, for selected years.................................. 8

3. Estimated seepage from the Sutherland Canal, Keith County, Nebraska, 1952-89 ........................................... 11

4. Estimated seepage gains and losses for Enders Reservoir during irrigation and nonirrigation periods, 1952-88 ....... 13

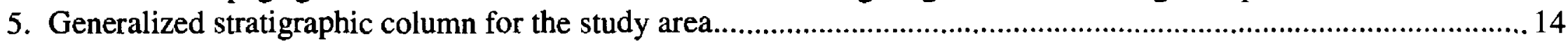

6. Base flow in 1952, 1975, and 1989 at selected seepage-measurement sites .....................................................25

7. Average streamflow at gaging stations within and near the study area, 1951-89............................................26

8. Simulation time intervals during which external hydraulic-head values assigned to general-head boundary cells remained the same

9. Hydraulic conductivity and specific yield estimated from description of materials comprising a lithologic unit........ 31

10. Average annual precipitation for weather stations in and near the study area, 1951-89 ........................................36

11. Output from soil-water program, given as annual averages, 1951-89, using data from the Haigler, Imperial, and

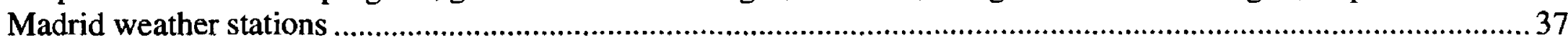

12. Comparison of measured and simulated streamflow at selected seepage-measurement sites in the study area........ .45

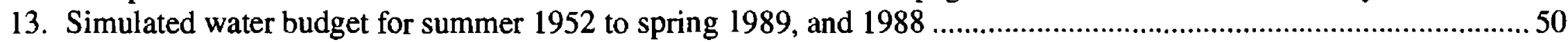

14. Comparison of streamflows simulated for 1989 and projected for 2010 and 2030 using the consumptive-irrigationrequirement and 13-inch scenarios at selected seepage-measurement sites in the study area.

IV Simuiated Response of the High Plains Aquifer to Ground-Water Withdrswsls, Upper Republlcsn Natursl Resources Distrlct, Nebrssks 


\section{CONVERSION FACTORS AND VERTICAL DATUM}

\begin{tabular}{rcl}
\hline Multiply & By & To obtain \\
acre & 4,047 & square meter \\
acre-foot & 1,233 & cubic meter \\
acre-foot per mile & 766.3 & cubic meter per kilometer \\
acre-foot per year & 1,233 & cubic meter per year \\
cubic foot per second & 0.02832 & cubic meter per second \\
foot & 0.3048 & meter \\
foot per day & 0.3048 & meter per day \\
foot per mile & 0.1894 & meter per kilometer \\
foot per year & 0.3048 & meter per day \\
inch & 25.4 & millimeter \\
inch per hour & 25.4 & millimeter per hour \\
inch per year & 25.4 & millimeter per year \\
mile & 1.609 & kilometer \\
million gallons per day & 0.04381 & cubic meter per second \\
square mile & 2.590 & square kilometer
\end{tabular}

Temperature can be converted to degrees Celsius $\left({ }^{\circ} \mathrm{C}\right)$ or degrees Fahrenheit $\left({ }^{\circ} \mathrm{F}\right)$ by using the following equations:

$$
\begin{gathered}
{ }^{\circ} \mathrm{C}=5 / 9\left({ }^{\circ} \mathrm{F}-32\right) \\
{ }^{\circ} \mathrm{F}=9 / 5\left({ }^{\circ} \mathrm{C}\right)+32 .
\end{gathered}
$$

Sea level: In this report, "sea level" refers to the National Geodetic Vertical Datum of 1929 (NGVD of 1929)—a geodetic datum derived from a general adjustment of the first-order level nets of both the United States and Canada, formerly called Sea Level Datum of 1929. 


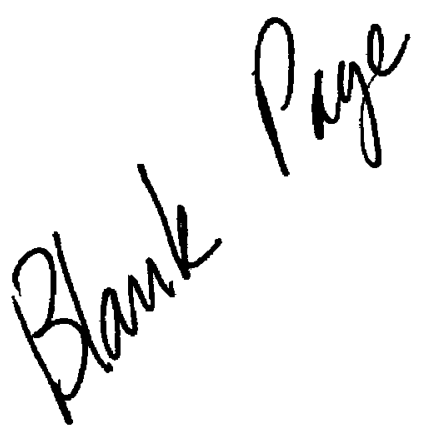

VI Simulated Response of the High Plains Aquifer to Ground-Water Withdrawais, Upper Repubilcan Naturai Resources District, Nebraaka 


\title{
Simulated Response of the High Plains Aquifer to Ground-Water Withdrawals in the Upper Republican Natural Resources District, Nebraska
}

\author{
By John M. Peckenpaugh ${ }^{1}$, Rich A. Kern², Jack T. Dugan', and John M. Kilpatrick ${ }^{1}$
}

\section{ABSTRACT}

A digital finite-difference model of the High Plains aquifer in the Upper Republican Natural Resources District, Nebraska, was deveoped to aid in the assessment of the effects of ground-water withdrawals on water levels in the aquifer and on streamflows in the study area. The model consisted of one layer, with the bottom of the aquifer modeled as a no-flow boundary. The northern and southern boundaries were the South Platte (northern boundary), Republican (southern boundary), and North Fork of the Republican Rivers (southern boundary), which were modeled as constant-head boundaries. The eastern and western boundaries of the model were placed a few miles beyond the eastern and western limits of the Natural Resources District because no natural boundaries were present. These boundaries were represented as general-head boundaries. The model was calibrated under both steady-state and transient (1952-89) conditions. The hydraulic conductivity of the aquifer used in the model ranged from 20 to 155 feet per day, and the specific yield used in the model ranged from 0.09 to 0.22 .

The long-term effects of two different pumping scenarios were evaluated for the period 1989-2030. In the first scenario, pumpage was held constant at a rate necessary to supply a crop's consumptive irrigation requirement. Simulated

\footnotetext{
${ }^{1}$ U.S. Geological Survey.

${ }^{2}$ Nebraska Natural Resources Commission.
}

water-level declines resulting from this pumping scenario were greatest in northwestern Chase County. A second scenario held pumpage constant at the rate necessary to apply 13 inches of water on irrigated crops during the irrigation season. Simulated water-level declines resulting from this scenario were larger than those for the first pumping scenario. Simulated water levels declined as much as 90 feet by 2030 in northwestern Chase County.

\section{INTRODUCTION}

Because of concern about declining groundwater levels in the Upper Republican Natural Resources District (NRD) (fig. 1) in the mid-1970's and diminishing inflow into Enders Reservoir, a detailed hydrogeologic study of the area was begun by the U.S. Geological Survey (USGS) in cooperation with the Conservation and Survey Division of the University of Nebraska-Lincoln and the Upper Republican NRD (Lappala, 1978). This study resulted in the development of a digital ground-water-flow model of the Upper Republican NRD north of the Republican and the North Fork of the Republican Rivers, a 5-mile-wide strip between the South Platte and the North Fork of the Republican Rivers in Colorado, and a portion of southern Keith County in Nebraska. This model was used to simulate groundwater flow for 1952-75.

Since the study was completed, the model has been updated twice by the Nebraska Natural Resources Commission (NRC) to incorporate more recent water-use and recharge data. The Upper Republican NRD continued to use the model to predict 


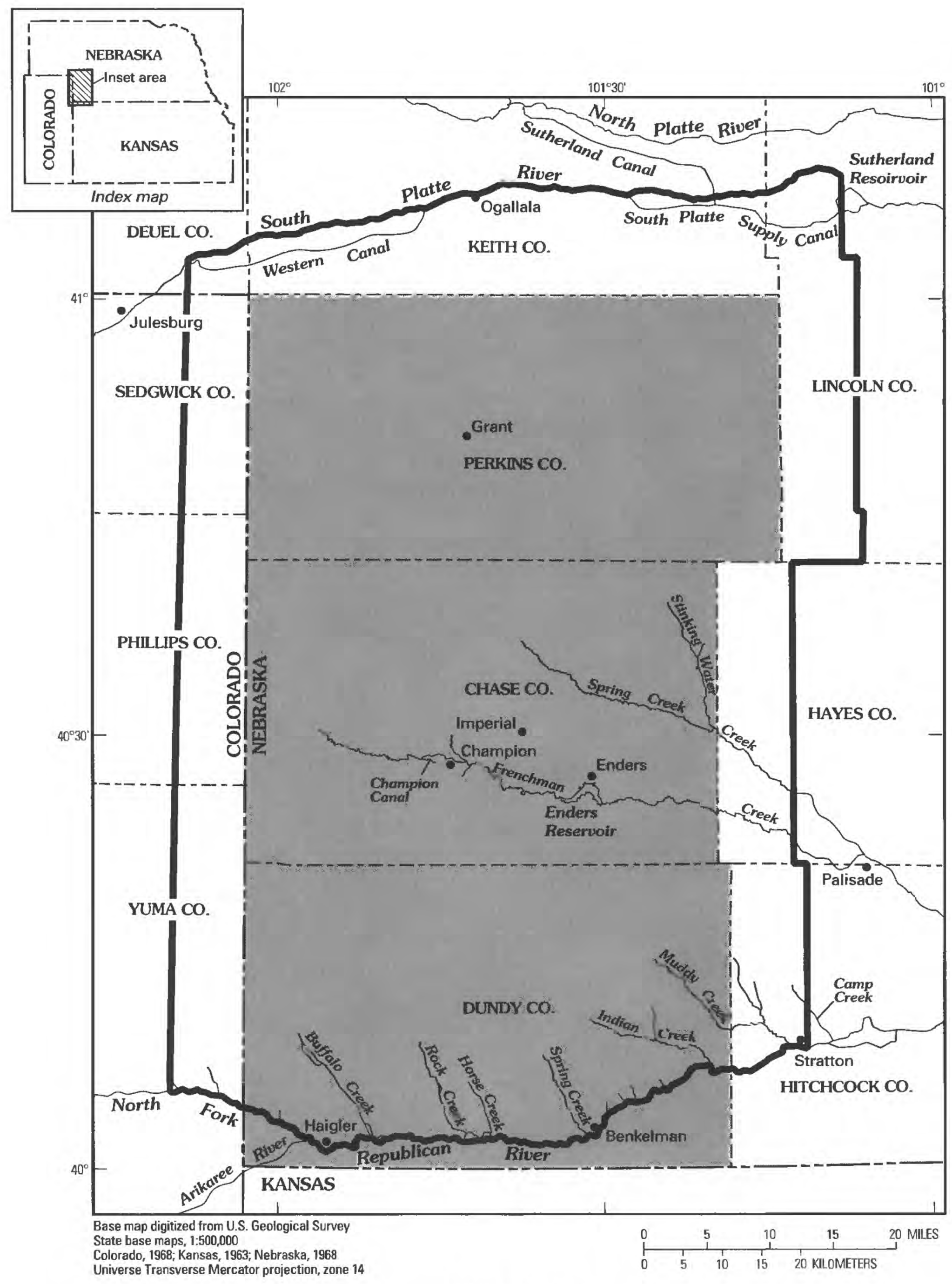

EXPLANATION

Upper Republican Natural Resources District

Boundary of study area

Figure 1. Location of study area and Upper Republican Natural Resources District.

2 Simulated Response of the Hlgh Plalns Aquifer to Ground-Water Withdrawals, Upper Republlcan Natural Resourcea Dlstrlct, Nebraska 
future ground-water-level changes. In recent years, water levels predicted by the model have differed in some areas from measured water levels. The most significant differences between predicted and measured water levels occurred in central Perkins and northwest Chase Counties. These differences may be because irrigation with center-pivot systems has expanded in these areas more rapidly than was foreseen when the model was developed in the mid1970's. To provide more accurate simulation of ground-water flow in these areas in the Upper Republican NRD, the USGS, as part of continuing cooperative studies with the Upper Republican NRD and the Nebraska NRC, updated this model using recently developed modeling software and incorporating data collected both before and after Lappala's (1978) study. The boundaries of this study are shown in figure 1.

\section{Purpose and Scope}

This report describes the hydrogeologic system in the study area and the development of a groundwater-flow model to quantitatively evaluate this system. Specifically, this report describes the hydrogeologic characteristics of the study area. This report also describes data manipulation, discretization, and estimation techniques used to compile the model arrays. Finally, this report describes the calibration of the model and its use in simulating water levels in the High Plains aquifer and streamflows resulting from two different pumping scenarios.

\section{Previous Studies}

The hydrogeology of the Republican River Valley was first described by Condra (1907) and was later described by Waite, Reed, and Jones (1946), Waite and others (1948), and Bradley and Johnson (1957). The hydrogeology of the Frenchman Creek Valley was described by Waite and others (1948) and Bradley and Johnson (1957). The hydrogeologic conditions in the South Platte River Valley were discussed by Bjorklund and Brown (1957). These studies included information on water levels, aquifer boundaries, and potential well yields.

Additional hydrogeologic studies that were not restricted to river valleys were conducted by Wenzel and Waite (1941) for Keith County, by Johnson (1960) for the northeast part of the study area, and by
Cardwell and Jenkins (1963) for the Frenchman Creek Basin within the study area. These investigations presented information on aquifer boundaries, saturated thickness, water levels, base of the aquifer, and water use. Redell (1967) discussed the distribution of ground-water recharge and discharge for the Colorado part of the study area.

The use of ground water for irrigation within the study area has been described by Cardwell (1953), Cardwell and Jenkins (1963), Boettcher (1966), Luckey (1973), Leonard and Huntoon (1974), Luckey and Hofstra (1974), the U.S. Bureau of Reclamation (1974), Lappala (1976, 1978), and Goeke and others (1992). Cardwell and Jenkins (1963) estimated stream depletion through the year 2000 caused by pumpage of ground water in and adjacent to the valleys of

Frenchman, Spring, and Stinking Water Creeks. Their estimates were reasonably accurate until extensive use of center-pivot irrigation systems began in the early 1970's.

Ground-water modeling studies have been used to provide information on the hydrogeologic system and on possible future effects of ground-water irrigation on water levels and streamflows. Investigations on this topic have been performed in parts of the study area or adjacent areas by Luckey (1973), Luckey and Hofstra (1974), Lappala (1978), Lappala and others (1979), Pettijohn and Chen (1983a, b), Luckey and others $(1986,1988)$, and Goeke and others (1992).

\section{Acknowledgments}

The authors appreciate the support, assistance, and cooperation during this study that was provided by the personnel, manager, and Board of Directors of the Upper Republican Natural Resources District and the staff of the Conservation and Survey Division, Institute of Agriculture and Natural Resources, University of Nebraska-Lincoln.

\section{DESCRIPTION OF THE STUDY AREA}

\section{Location and Physiography}

The study area encompasses approximately 3,750 square miles and includes parts or all of 11 counties in Nebraska and Colorado (fig. 1). These counties are Chase, Deuel, Dundy, Hayes, Hitchcock, Keith, Lincoln, and Perkins Counties in Nebraska, and 
Phillips, Sedgwick, and Yuma Counties in Colorado. The study area lies in the High Plains Section of the Great Plains Province (Fenneman, 1931). Landsurface altitudes range from 2,800 feet in Hitchcock County, Nebraska, where the Republican River crosses the eastern study-area boundary, to 3,750 feet in northeastern Sedgwick County, Colorado. The land surface generally slopes to the east at about 10 feet per mile. The physiographic features of the study area can be divided into five main categories: loess plains and tablelands, rolling uplands, sand hills and interdune valleys, dissected plains and uplands, and bottom lands along major water courses. A detailed description of each of these areas can be found in Lappala (1978, p. 4-5). Most of the study area can be categorized as rolling uplands or sand hills and interdune valleys.

\section{Climate}

The climate of the Upper Republican NRD is transitional between continental subhumid and semiarid, with semiarid conditions predominant in most years. Winters are normally cold, and summers are usually hot. Average annual precipitation (1951-89) ranges from about 17 inches in the northwestern and southwestern parts of the study area to nearly 20 inches in the southeastern part (fig. 2). Annual amounts, however, are quite variable. During 1951-89, Imperial, in Chase County, with an annual average of 19.02 inches, had 5 years of greater than 25 inches and 6 years of less than 15 inches of annual precipitation (National Oceanic and Atmospheric Administration, 1951-89).

About 75 percent of the annual precipitation occurs during the warm season (April-September). This peak precipitation season coincides with large rates of evapotranspiration, which generally results in no seasonal surplus of soil water. Warm-season precipitation, which often occurs as small, scattered thunderstorms, generally is distributed irregularly within the study area. The cool season (OctoberMarch) is often very dry.

Annual potential evapotranspiration (PET), which is affected by such factors as solar radiation, air and soil temperatures, humidity, and wind, ranges from about 50 inches in the northeastern part of the study area to about 66 inches in the southwestern part and averages about 53 inches, as computed by the Jensen-Haise method (Jensen and others, 1970). A combination of a high percentage of possible sunshine, high temperatures, low humidity, and high average wind speed, particularly during the warm season, contributes to these large PET values. Warm-season PET (April-September) averages about 42 inches, which is about 80 percent of the annual average for the study area.

\section{Soils}

The soils in the study area are quite variable because of differences in parent materials, but they can be grouped into eight mappable units (fig. 3 and table 1). Each mappable soil unit consists of a soil series grouped principally by hydrologic characteristics including permeability, available water capacity, and slope. The mappable soil units that include soils of the bottom lands and terraces tend to include diverse soils that exhibit great differences among their hydrologic characteristics. The complex distribution and small area often covered by these soils necessitate the grouping of somewhat different soils for mapping considerations.

Classified by texture, permeability, and available water capacity (Dugan, 1984), upland soils can be placed in three groups reflecting the parent-material differences-silt loam to silty clay loam soils (available water capacity, 0.18 to 0.21 inch per inch), sandy soils (available water capacity, 0.05 to 0.08 inch per inch), and sandy loam soils transitional between the silty and sandy soils (available water capacity, 0.11 to 0.17 inch per inch). The silty upland soils are classified further into three slope groups to reflect surfacerunoff potential and irrigability-nearly level to undulating ( 0 to 7 percent), undulating to rolling ( 7 to 15 percent), and rolling to very steep ( 15 to 45 percent). Very steep silty soils are severely dissected or eroded.

Bottom land and terrace soils compose only about 5 percent of the soils in the study area. These soils have been classified into two groups - the sandy loam to silt loam soils (available water capacity, 0.13 to 0.19 inch per inch) and the sandy to sandy loam soils (available water capacity, 0.04 to 0.13 inch per inch). The large ranges in available water capacity in these soils reflect the large range of soil-texture types included in these mappable soil units.

The irrigation potential of the soils in the study area is quite variable, ranging from 10 to 100 percent (table 1). The irrigation potential is the percentage of a 


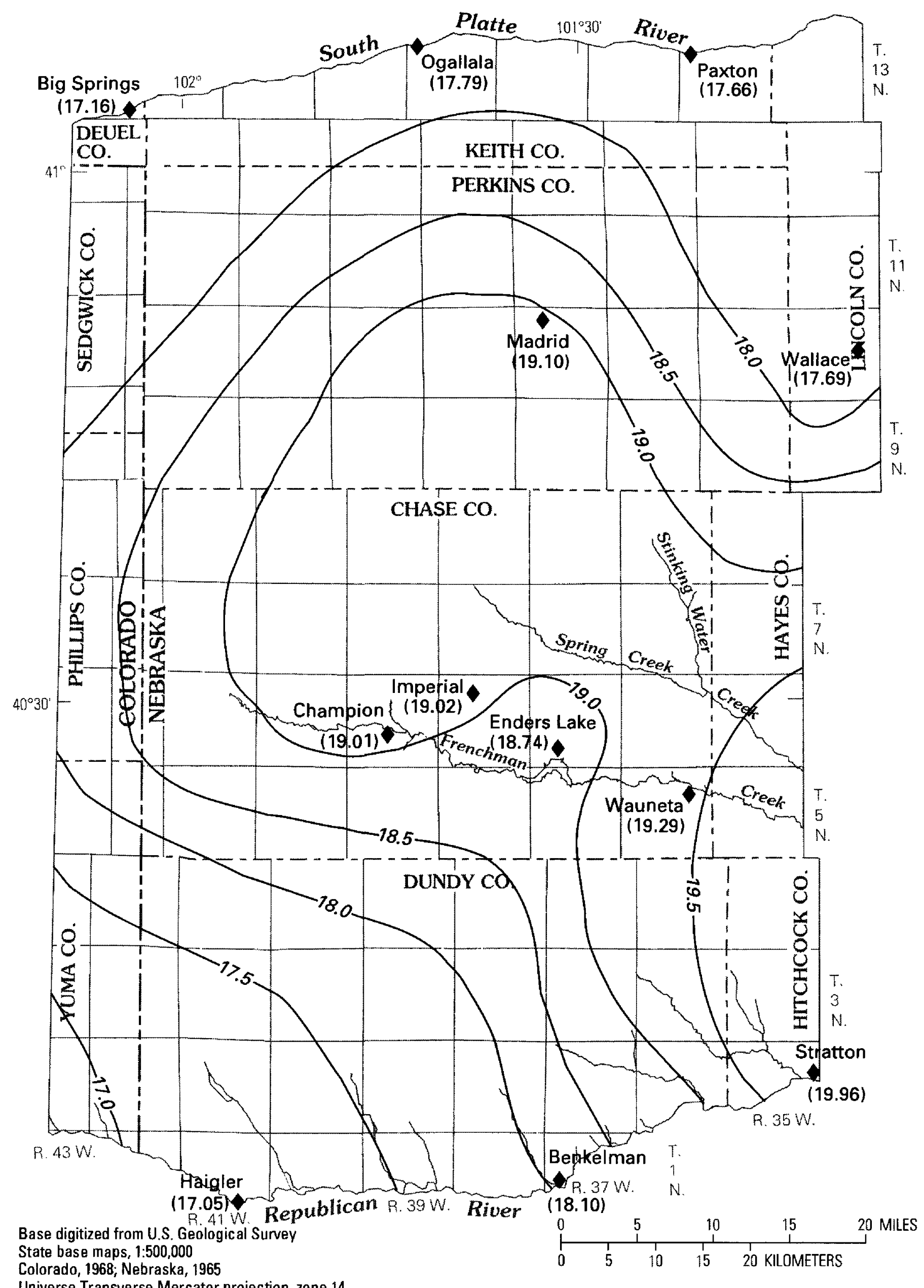

State base maps, 1:500,000

Universe Transverse Mercator projection, zone 14

\section{EXPLANATION}

-17.0 - Line of equal average precipitation, 1951-89Interval 0.5 inch

Haigler
$(17.05)$ Weather station and name-Number in parentheses is average annual precipitation, 1951-89, in inches

Figure 2. Average annual precipitation, 1951-89, and location of selected weather stations (data from National Oceanic and Atmospheric Administration, 1951-89). 


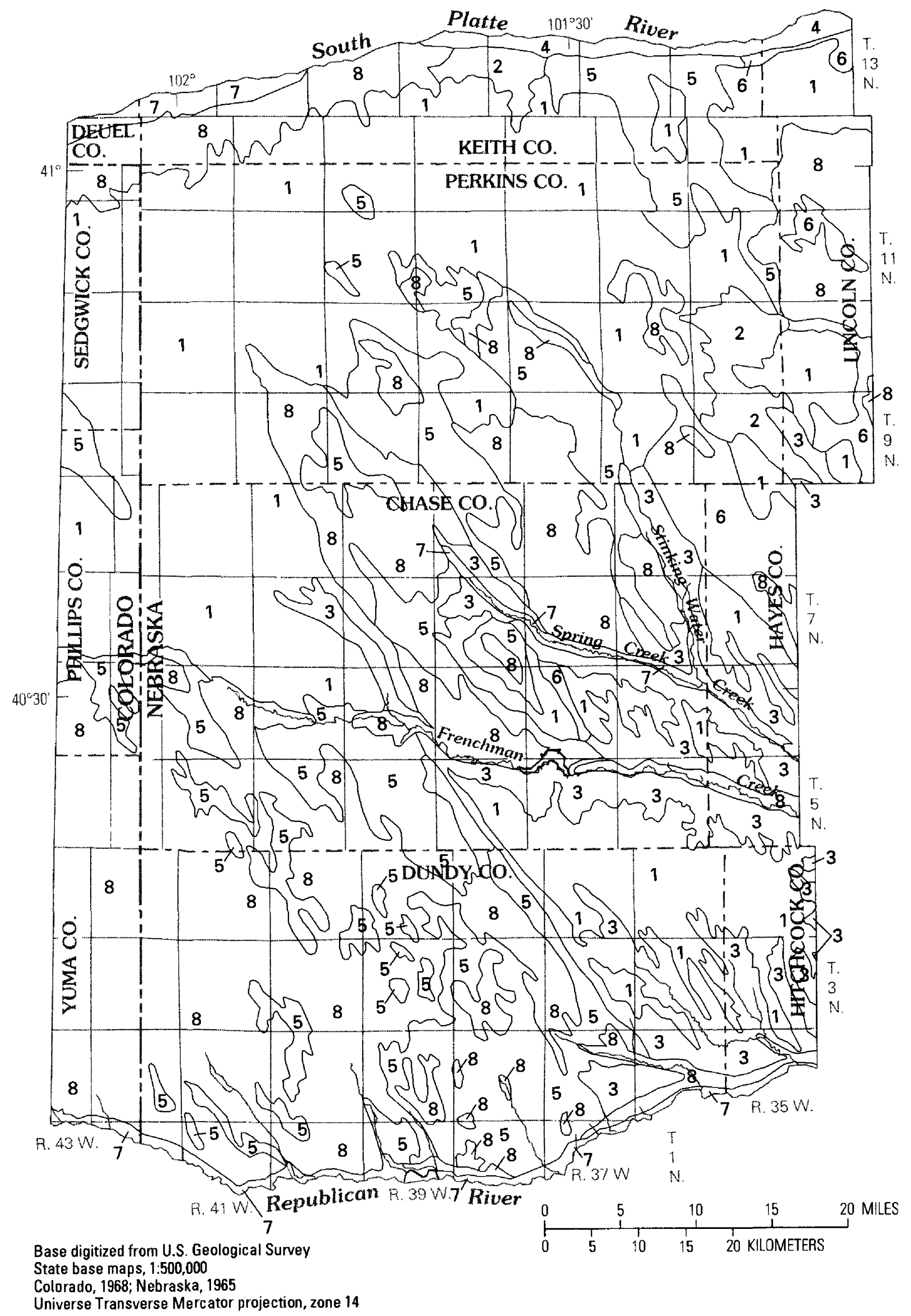

\section{EXPLANATION}

Mappable soil units-See table 1

for a description of each unit

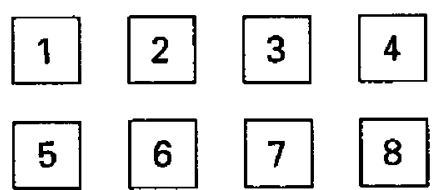

Figure 3. Distribution of mappable soil units (modified from Dugan, 1984). 
Table 1. Mappable soil units in the study area and their hydrologic characteristics

\begin{tabular}{|c|c|c|c|c|c|c|c|}
\hline $\begin{array}{l}\text { Mappable } \\
\text { soil unit } \\
\text { (fig. 3) }\end{array}$ & Texture & $\begin{array}{l}\text { Range of } \\
\text { perme- } \\
\text { ability } \\
\text { (inches per } \\
\text { hour) }\end{array}$ & $\begin{array}{l}\text { Average } \\
\text { available } \\
\text { water } \\
\text { capacity } \\
\text { (inch per } \\
\text { inch) }\end{array}$ & $\begin{array}{l}\text { Range of } \\
\text { slope } \\
\text { (percent) }\end{array}$ & $\begin{array}{l}\text { Topo- } \\
\text { graphic } \\
\text { position }\end{array}$ & Soil serles represented & $\begin{array}{l}\text { Irrigatlon } \\
\text { potential } \\
\text { (percent) }\end{array}$ \\
\hline 1 & $\begin{array}{l}\text { Silt loam to silty } \\
\text { clay loam }\end{array}$ & 1.0 to 1.5 & 0.18 & 0 to 7 & Uplands & $\begin{array}{l}\text { Rosebud, Alliance, Kuma, } \\
\text { Goshen, Keith }\end{array}$ & 100 \\
\hline 2 & $\begin{array}{l}\text { Silt loam to silty } \\
\text { clay loam }\end{array}$ & 1.0 to 1.5 & .21 & 7 to 15 & Uplands & Ulysses, Keith, Colby & 85 \\
\hline 3 & $\begin{array}{l}\text { Silt loam to silty } \\
\text { clay loam }\end{array}$ & 1.0 to 1.5 & .20 & 15 to 45 & Uplands & Colby, Canyon, Ulysses & 20 \\
\hline 4 & $\begin{array}{l}\text { Sandy loam to } \\
\text { silt loam }\end{array}$ & 1.5 to 3.0 & .17 & 0 to 7 & $\begin{array}{l}\text { Bottom } \\
\text { lands } \\
\text { and terraces }\end{array}$ & $\begin{array}{l}\text { Bridget, McCook, Duroc, } \\
\text { Bankard, Las, Glenburg }\end{array}$ & 100 \\
\hline 5 & $\begin{array}{l}\text { Sandy loam to } \\
\text { silt loam }\end{array}$ & 2.5 to 5.0 & .15 & 0 to 7 & Uplands & $\begin{array}{l}\text { Jayem, Haxtun, Rosebud, } \\
\text { Keith }\end{array}$ & 100 \\
\hline 6 & $\begin{array}{l}\text { Fine sand to } \\
\text { sandy loam }\end{array}$ & 5.0 to 7.0 & .12 & 0 to 15 & Uplands & $\begin{array}{l}\text { Jayem, Sarben, Valent, } \\
\text { Hersch, Valentine }\end{array}$ & 80 \\
\hline 7 & $\begin{array}{l}\text { Fine sand to } \\
\text { sandy loam }\end{array}$ & 7.0 to 12.0 & .11 & 0 to 3 & $\begin{array}{l}\text { Bottom } \\
\text { lands } \\
\text { and terraces }\end{array}$ & $\begin{array}{l}\text { Gothenburg, Platte, Las, } \\
\text { Las Animas }\end{array}$ & 10 \\
\hline 8 & $\begin{array}{l}\text { Sand to dune } \\
\text { sand }\end{array}$ & 12.0 to 20.0 & .07 & 0 to 45 & Uplands & Valent, Valentine, Tassel & 30 \\
\hline
\end{tabular}

${ }^{1}$ David Lewis, Department of Agronomy, University of Nebraska-Lincoln, written commun, 1988.

soil association that is potentially capable of sustained irrigation with current irrigation technology. This potential irrigability reflects slope and soil-depth characteristics but does not necessarily reflect available water or best-management practices (David Lewis, Department of Agronomy, University of Nebraska-Lincoln, written commun., 1988).

\section{Land Use}

Soils and topography largely determine land use in the study area. Soils derived from sand dunes or with large topographic slopes, such as those included in mappable soil unit 8 (table 1), often are left uncultivated and in native vegetation. Soils with less sloping topography and less sandy textures, including mappable soil units $1,2,4,5$, and 6 (table 1 ), generally are well suited for cultivation and irrigation.

About 40 percent of the area is currently grassland (all pasture and rangeland not harvested for hay). Cultivated land, including unharvested crop and fallow, accounts for slightly more than 50 percent of the area. Less than 5 percent of the area is used for nonagricultural purposes, including transportation, communication, farmstead, commercial, and urban functions. Natural woodlands occupy less than 1 percent of the study area (U.S. Department of Commerce, Bureau of the Census, 1989). Natural woodlands generally occur only along permanent streams and consist largely of phreatophytes, such as willows and cottonwoods, that thrive under shallow water-table conditions (Weaver and Albertson, 1956; Kaul and Rolfsmeier, 1993).

Vegetation or land-use changes through time have occurred largely on cultivated land. Although the percentage of land area classified as cultivated has remained generally constant through time, small, short-term fluctuations have occurred as some rangeland has been cultivated temporarily but later allowed to revert to rangeland depending on the agricultural economy. Large changes in cropping patterns have occurred on cultivated land related to irrigation development and changes in the agricultural economy (table 2). 


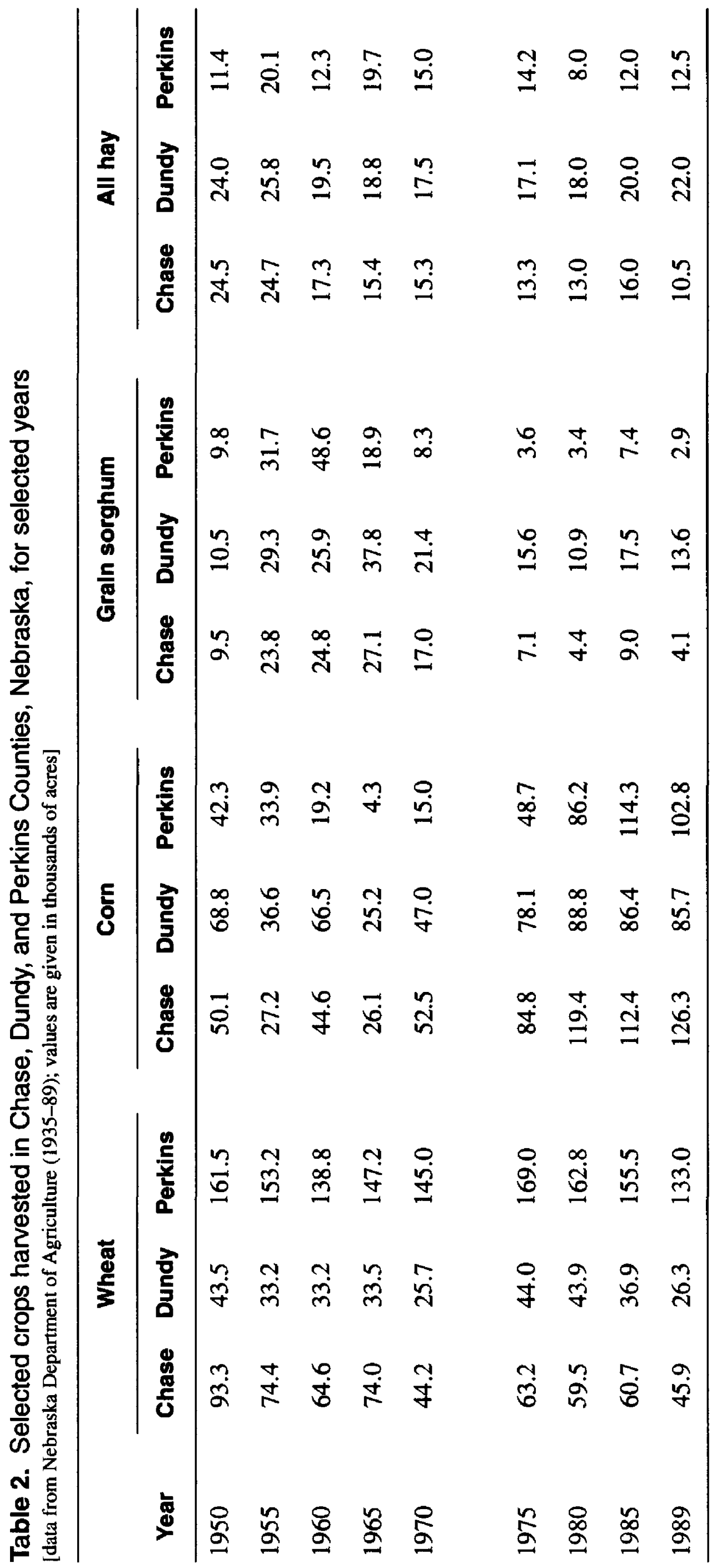

8 Simulated Response of the High Plains Aquifer to Ground-Water Withdrawals, Upper Republican Natural Resource District, Nebraaka 
Since 1950, total acreage of crops harvested has not changed substantially in the study area, but crop types have shown considerable variability. Wheat acreages have decreased gradually, while corn acreages have increased substantially. Grain sorghum acreages also have decreased gradually through time. These changes are related principally to the widespread development of ground-water irrigation between the mid-1960's and the late 1970's and, to a lesser extent, to changes in government agricultural programs.

\section{DESCRIPTION OF THE HYDROGEOLOGIC SYSTEM}

The study area is characterized by generally plentiful ground-water resources and generally less plentiful surface-water resources. Increased use of ground-water supplies for irrigation since development began has affected the availability of both ground- and surface-water supplies. The following sections briefly describe the hydrogeologic system and the effects of ground-water development on the availability of water.

\section{Surface-Water System}

The surface-water system in the study area consists of several major components including streams, canals, and reservoirs. These components interact with each other and the aquifer system in a complex manner. The schematic diagram shown in figure 4 delineates the relations among the different streams, canals, and reservoirs in the study area and also lists average annual streamflow at selected gaging stations.

\section{Streams}

The South Platte and Republican Rivers are the major stream systems in the study area. The South Platte River, which forms the northern boundary of the area, has no perennial tributaries in the study area. There are, however, canal diversions, a canal return, and intermittent draws that are connected to the South Platte River. The Republican River and the North Fork of the Republican River, which form the southern boundary of the study area, have several tributaries within the area: Stinking Water, Frenchman, and Spring Creeks in Chase County and Buffalo, Rock,
Horse, Spring, Indian, and Muddy Creeks in Dundy County. The Republican River and North Fork of the Republican River have no canal diversions or canal returns within the study area.

\section{Canals}

Several canals in the study area divert water from streams for use as irrigation or cooling water (figs. 1 and 4). The Western and Champion Canals provide water for irrigation in the study area. The Champion Canal is not shown in figure 4 because of its small length and small average annual diversion. The Western Canal began operation in 1918 and has diverted an average of 26,900 acre-feet per year since 1952 from the South Platte River. The smaller Champion Canal began operation in 1963 and has diverted about 2,400 acre-feet per year from Frenchman Creek (Nebraska Department of Water Resources, 1935-89).

The South Platte Supply and Sutherland Canals divert water in the study area for use as cooling water. The South Platte Supply Canal diverts water from the South Platte River in Keith County and flows along the south side of the South Platte River until it joins the Sutherland Canal (figs. 1 and 4). The Sutherland Canal carries water diverted from the North Platte River (16 miles to the northwest) and has diverted approximately 638,000 acre-feet of water per year, whereas the South Platte Supply Canal has diverted 216,000 acre-feet per year since 1952 (Nebraska Department of Water Resources, 1935-89). The diversions from these two canals, both of which began operation in 1935, are stored at the Sutherland Reservoir, immediately east of the study area (fig. 1). Water stored in the Sutherland Reservoir is used to provide cooling water for condensers at a steam powerplant adjacent to the reservoir.

A substantial amount of the water diverted into canals in the study area is lost as seepage into the underlying High Plains aquifer. For this study, the seepage losses from the Western Canal were assumed to be 40 percent of the annual diversion, based on losses from other canals in the vicinity. Estimated annual seepage losses from 1952-89 from the Sutherland Canal are listed in table 3. The average annual seepage loss per mile during this time period was about 1,254 acre-feet. The seepage losses from the South Platte Supply Canal were estimated to be about 35 percent of the Sutherland Canal seepage losses or about 500 acre-feet per mile of the canal's 

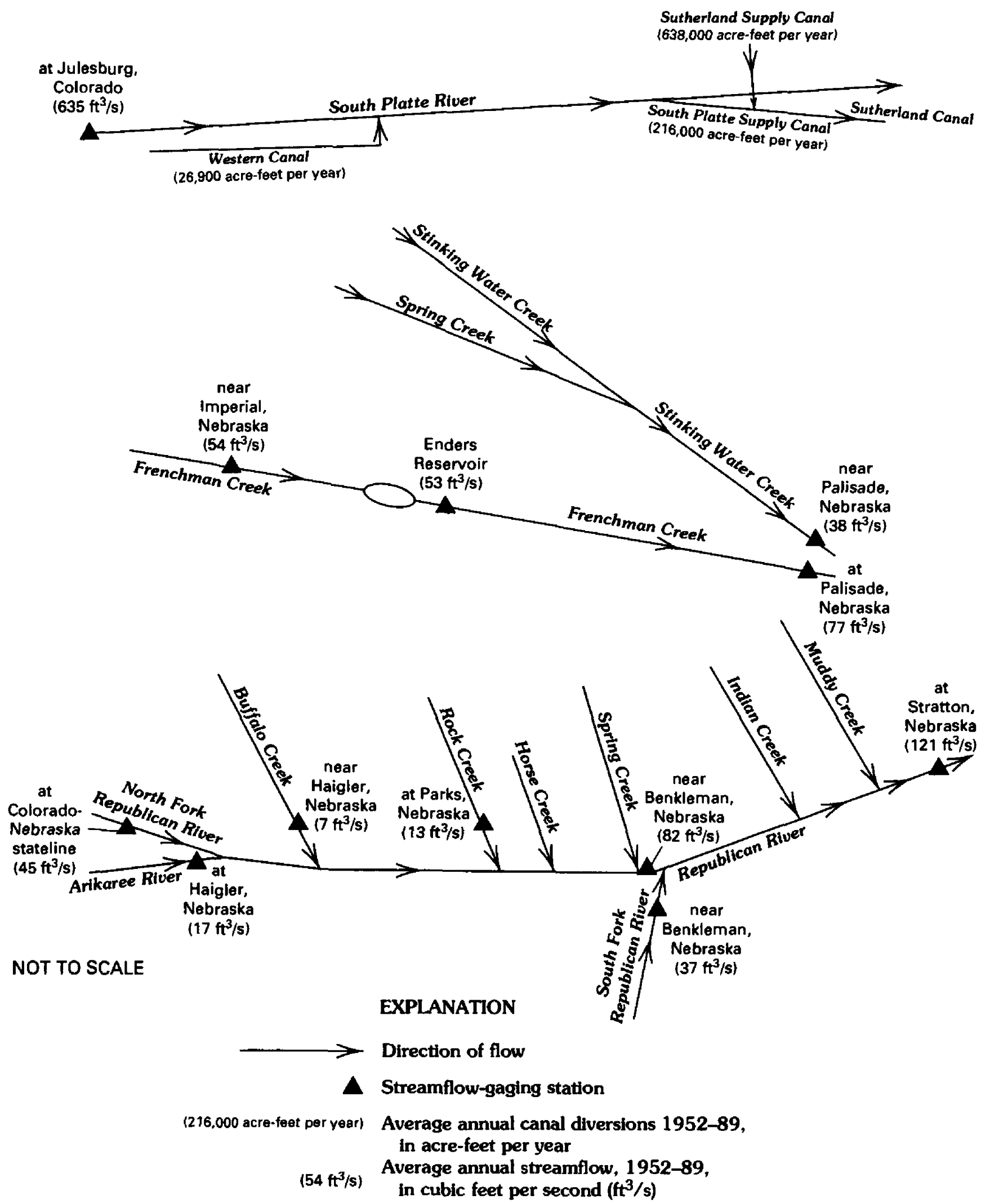

Figure 4. Schematic diagram of the surface-water system in the study area.

length. A detailed description of the methods used to estimate seepage in these and other similar canals can be found in Goeke and others (1992, p. 20).

\section{Lakes and Reservoirs}

Enders Reservoir is the only surface-water impoundment in the study area that has a storage capacity greater than 1,000 acre-feet. No permanent natural lakes exist in the study area. Numerous small impoundments exist, but their capacity is unknown; however, surface-water storage rights have been granted for 50,150 acre-feet by the Nebraska Department of Water Resources (Lappala, 1978).

Enders Reservoir has an average surface area of 1,242 acres. Enders Reservoir, which began filling in October 1950, is used for storing irrigation water derived from Frenchman Creek. Water is released from Enders Reservoir into Frenchman Creek during the irrigation season and flows out of the study area to a 
Table 3. Estimated seepage from the Sutherland Canal, Keith County, Nebraska, 1952-89

\begin{tabular}{|c|c|c|}
\hline Year & $\begin{array}{c}\text { Total annual seepage } \\
\text { (acre-feet) }\end{array}$ & $\begin{array}{l}\text { Seepage per mile } \\
\text { (acre-feet per mile) }\end{array}$ \\
\hline 1952 & 16,864 & 1,382 \\
\hline 1953 & 22,221 & 1,821 \\
\hline 1954 & 13,460 & 1,103 \\
\hline 1955 & 19,361 & 1,587 \\
\hline 1956 & 17,064 & 1,399 \\
\hline 1957 & 12,670 & 1,039 \\
\hline 1958 & 12,194 & 1,000 \\
\hline 1959 & 11,225 & 920 \\
\hline 1960 & 11,711 & 960 \\
\hline 1961 & 11,625 & 953 \\
\hline 1962 & 9,953 & 816 \\
\hline 1963 & 15,196 & 1,246 \\
\hline 1964 & 14,517 & 1,190 \\
\hline 1965 & 8,622 & 707 \\
\hline 1966 & 11,952 & 980 \\
\hline 1967 & 16,241 & 1,331 \\
\hline 1968 & 14,416 & 1,182 \\
\hline 1969 & 11,384 & 933 \\
\hline 1970 & 15,676 & 1,285 \\
\hline 1971 & 16,603 & 1,361 \\
\hline 1972 & 16,681 & 1,367 \\
\hline 1973 & 14,631 & 1,199 \\
\hline 1974 & 15,775 & 1,293 \\
\hline 1975 & 9,557 & 783 \\
\hline 1976 & 14,652 & 1,201 \\
\hline 1977 & 15,299 & 1,254 \\
\hline 1978 & 14,579 & 1,195 \\
\hline 1979 & 16,287 & 1,335 \\
\hline 1980 & 19,105 & 1,566 \\
\hline 1981 & 18,288 & 1,499 \\
\hline 1982 & 13,554 & 1,111 \\
\hline 1983 & 15,250 & 1,250 \\
\hline 1984 & 19,740 & 1,618 \\
\hline 1985 & 16,531 & 1,355 \\
\hline 1986 & 19,910 & 1,632 \\
\hline 1987 & 20,899 & 1,713 \\
\hline 1988 & 20,972 & 1,719 \\
\hline 1989 & 16,812 & 1,378 \\
\hline Average annual seepage & 15,302 & 1,254 \\
\hline
\end{tabular}

\footnotetext{
${ }^{1}$ The Sutherland Canal within the study area is 12.2 miles in length.
} 
diversion dam. Enders Reservoir provides no irrigation water for lands within the study area.

Seepage losses from Enders Reservoir were estimated using monthly inflow-outflow data from 1951 through 1988, collected by the U.S. Bureau of Reclamation, and the following equation, which was modified from Lappala (1978):

$$
Q_{s}=Q_{I}-Q_{E}-(E-P) A \pm(\Delta s) /(\Delta t)
$$

where

$$
\begin{aligned}
& Q_{s} \quad=\text { reservoir seepage }\left[\mathrm{L}^{3} \mathrm{~T}^{-1}\right] \\
& \text { (positive values represent ground- } \\
& \text { water recharge, and negative values } \\
& \text { represent ground-water discharge to } \\
& \text { surface water); } \\
& Q_{l} \quad=\text { average monthly reservoir inflow, } \\
& \text { which includes gaged and estimated } \\
& \text { ungaged flows }\left[\mathrm{L}^{3} \mathrm{~T}^{-1}\right] \text {; } \\
& Q_{E} \quad=\text { average monthly reservoir release as } \\
& \text { measured at the streamflow-gaging } \\
& \text { station near Enders }\left[\mathrm{L}^{3} \mathrm{~T}^{-1}\right] \text {; } \\
& E \quad=\text { monthly lake evaporation at Enders } \\
& {\left[\mathrm{LT}^{-1}\right] \text {; }} \\
& P \quad=\text { monthly precipitation at Enders } \\
& {\left[\mathrm{LT}^{-1}\right] \text {; }} \\
& A=\text { end-of-month reservoir surface area } \\
& \text { [L']; } \\
& \Delta s \quad=\text { monthly change in storage }\left[\mathrm{L}^{3}\right] ; \text { and } \\
& \Delta t \quad=\text { time increment of study (1 month) }
\end{aligned}
$$$$
\text { [T]. }
$$

The estimated seepage fluxes into and out of

Enders Reservoir are listed in table 4 for irrigation and nonirrigation periods from 1952 through 1988 . These data indicate that the reservoir was predominately losing water to the High Plains aquifer prior to 1959. However, since 1959, the aquifer has been predominantly discharging water to the reservoir.

\section{Ground-Water System}

\section{Geology}

The youngest geologic unit underlying the entire study area is the Pierre Shale of Cretaceous age (table 5). The Pierre Shale consists mostly of blue, ochre, or black-colored shale and clay. The Pierre Shale is the uppermost bedrock unit in the study area, except in parts of Chase, Perkins, and Keith Counties, where it is overlain by the White River Group (fig. 5).
The White River Group consists of two formations, the lower of which is the Chadron Formation and the upper of which is the Brule Formation. The Chadron Formation generally consists of olive-green to brick-red silty to sandy clay and claystone (Cardwell and Jenkins, 1963), whereas the Brule Formation, which conformably overlies the Chadron Formation, contains buff to olive-green clayey silt and siltstone. Where present, these units are overlain by the Ogallala Formation of Tertiary age. The Ogallala Formation directly overlies the Pierre Shale where the White River Group is absent.

The Ogallala Formation underlies all but the extreme southern and northwestern parts of the study area (fig. 6). It ranges in thickness from a feathered edge to more than 400 feet (Cardwell and Jenkins, 1963, p. 42). The Ogallala Formation consists of beds of silt, sand, gravel, caliche, and clay, with considerable variability in lithology within short vertical or horizontal distances. These variations are consistent with the fluvial environment in which the Ogallala was deposited. This environment was characterized by a series of braided streams carrying sediment eastward. Some of the sand and gravel deposits are weakly cemented by calcium carbonate into rocks ranging from friable sandstone to relatively hard, ledge-forming mortar beds (Cardwell and Jenkins, 1963, p. 42). Except in a few areas, most notably western Perkins and Chase Counties, the Ogallala Formation is overlain by unconsolidated Quaternary deposits.

The unconsolidated Quaternary deposits, which comprise the land surface of most of the study area, consist of sand, gravel, silt, and clay of fluvial origin and sand, silt, and clay of eolian origin. These deposits range in thickness from a feathered edge to more than 100 feet. These deposits occur as alluvium and terraces in stream valleys and dune sand and loess deposits in upland areas and on high terraces.

\section{High Plains Aquifer}

The uppermost aquifer in the study area is the High Plains aquifer (Pettijohn and Chen, 1983a). It consists of the saturated parts of the Quaternary deposits and the underlying Ogallala Formation. This aquifer is unconfined, and its upper surface is the water table. In the spring of 1989 , water-table altitudes in the study area ranged from more than 3,600 feet in Yuma County, Colorado, to less than 2,800 feet in Hitchcock County, Nebraska (fig. 7). In general, the direction of regional ground-water flow in 
Table 4. Estimated seepage gains and losses for Enders Reservoir during irrigation and nonirrigation periods, 1952-88

\begin{tabular}{|c|c|c|}
\hline \multirow[b]{2}{*}{ Year } & \multicolumn{2}{|c|}{$\begin{array}{c}\text { Fluxes }^{1} \\
\text { (scre-feet) }\end{array}$} \\
\hline & Irrigation ${ }^{2}$ & Nonirrlgation ${ }^{2}$ \\
\hline 1952 & 500 & 3,400 \\
\hline 1953 & -400 & 900 \\
\hline 1954 & 400 & 4,600 \\
\hline 1955 & -100 & 2,000 \\
\hline 1956 & -700 & 1,000 \\
\hline 1957 & 100 & 1,700 \\
\hline 1958 & -600 & 800 \\
\hline 1959 & $-1,400$ & $-1,800$ \\
\hline 1960 & $-1,600$ & -200 \\
\hline 1961 & $-3,200$ & $-3,100$ \\
\hline 1962 & $-2,500$ & $-4,300$ \\
\hline 1963 & $-3,100$ & $-1,500$ \\
\hline 1964 & $-2,500$ & $-1,900$ \\
\hline 1965 & $-3,800$ & -500 \\
\hline 1966 & $-5,000$ & $-1,700$ \\
\hline 1967 & $-2,500$ & $-1,200$ \\
\hline 1968 & $-5,100$ & $-2,600$ \\
\hline 1969 & $-3,200$ & $-3,200$ \\
\hline 1970 & $-3,200$ & $-2,300$ \\
\hline 1971 & $-3,700$ & $-1,500$ \\
\hline 1972 & -700 & $-2,500$ \\
\hline 1973 & $-3,400$ & $-2,400$ \\
\hline 1974 & $-2,300$ & -800 \\
\hline 1975 & $-1,700$ & $-1,500$ \\
\hline 1976 & $-2,600$ & $-1,500$ \\
\hline 1977 & $-2,500$ & $-1,900$ \\
\hline 1978 & -800 & $-2,700$ \\
\hline 1979 & $-1,700$ & $-3,400$ \\
\hline 1980 & $-1,600$ & $-3,200$ \\
\hline 1981 & $-1,000$ & $-1,400$ \\
\hline 1982 & $-1,600$ & 8,300 \\
\hline 1983 & -900 & $-1,500$ \\
\hline 1984 & $-1,300$ & $-2,400$ \\
\hline 1985 & -900 & $-1,200$ \\
\hline 1986 & $-2,200$ & $-2,500$ \\
\hline 1987 & $-3,500$ & $-2,600$ \\
\hline 1988 & -800 & $-1,900$ \\
\hline
\end{tabular}

\footnotetext{
${ }^{1}$ Negative (-) fluxes are ground-water seepage losses to surface water; positive fluxes are ground-water gains from surface water.

${ }^{2}$ Irrigation period is June through August, and nonirrigation period is January through May and September through December.
} 
Table 5. Generalized stratigraphic column for the study area

[modified from Cardwell and Jenkins, 1963]

\begin{tabular}{|c|c|c|c|c|}
\hline Erathem & System & Series & & Stratigraphic unit \\
\hline \multirow{5}{*}{ Cenozoic } & \multirow{2}{*}{ Quaternary } & Holocene & \multicolumn{2}{|c|}{ Alluvium and terrace deposits } \\
\hline & & Holocene and Pleistocene & \multicolumn{2}{|c|}{ Dune sand } \\
\hline & \multirow{3}{*}{ Tertiary } & Pliocene & \multicolumn{2}{|c|}{ Ogallala Formation } \\
\hline & & \multirow{2}{*}{ Oligocene } & \multirow{2}{*}{ 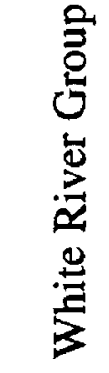 } & Brule Formation \\
\hline & & & & Chadron Formation \\
\hline Mesozoic & Cretaceous & Upper Cretaceous & \multicolumn{2}{|c|}{ Pierre Shale } \\
\hline
\end{tabular}

the study area is west to east except in the vicinity of the Republican River, a prominent discharge area. Average ground-water-flow velocities range from less than 50 to more than 200 feet per year.

The White River Group and the Pierre Shale are relatively impermeable in the study area (Cardwell and Jenkins, 1963, p. 34, 36, 40) and form the base of the High Plains aquifer (fig. 8). Figure 8 was constructed on the basis of analysis of driller's or geologist's logs from 149 test holes and 1,174 irrigation wells. Several drainage channels are distinguishable on this erosional surface, which slopes generally to the east at about 20 feet per mile (Lappala, 1978).

The volume of ground water in storage in the High Plains aquifer is a function of the saturated thickness of the aquifer, the area that the aquifer covers, and the porosity of the aquifer. The porosity of the aquifer is estimated to range from 0.30 to 0.40 (Lappala, 1978). Therefore, the volume of water in storage is estimated to be 189 million acre-feet in 1952 and 168 million acre-feet in 1989 using the same method as Lappala (1978). All of this water cannot be withdrawn by dewatering or pumping because some water molecules cling to rock or soil particles due to the surface tension of water. On the basis of a typical specific-yield value for the aquifer of 0.18 , the amount of recoverable or available water in the High Plains aquifer was estimated to be 97 and 86 million acre-feet in 1952 and 1989, respectively.

\section{Aquifer Development and Associated Effects}

The first irrigation well in the area was completed in 1913 in Champion, Nebraska, and only a few additional wells were dug in the following 20 years (Cardwell and Jenkins, 1963, p. 88). Between the mid-1930's and mid-1950's, more than 90 additional irrigation wells were constructed (fig. 9). The earliest measured water levels date from this period and were used to estimate the spring 1952 water table shown in figure 10. This water-table map was developed by Lappala (1978) from water levels measured from 1937 to 1952. A detailed discussion describing the sources of the water levels used to construct figure 10 is presented in Lappala (1978). During the 1960's and 1970 's, the number of irrigation wells greatly increased so that by 1975 there were more than 1,700 registered irrigation wells in the study area (fig. 11). Almost one-half of these wells were in Chase County. A rapid increase in drilling during the late 1970's brought the number of registered irrigation wells to approximately 2,800 in 1980 . Drilling activity leveled off in the 1980's, with only about 400 additional wells drilled by 1989 (fig. 12). Water use for irrigation from the High Plains aquifer in Chase, Perkins, and Dundy Counties was estimated to be about 520,000 acre-feet per year in 1985 (Steele, 1988).

Increased utilization of ground water from the High Plains aquifer has had a substantial effect on water levels in the aquifer and on rates of groundwater seepage from the aquifer into area streams. 




Figure 5. Geologic section $B-B$, modified from Lappala (1978). Trace of section shown in figure 6.

These effects are readily apparent by comparing hydrologic conditions before substantial use of ground water for irrigation (1952) with those in 1989. A comparison of the water-level surface in the High Plains aquifer in 1952 (fig. 10) with the same surface in 1989 (fig. 7) reveals extensive water-level declines in Dundy and Chase Counties. This is most apparent in figure 13, which illustrates the difference in water levels from these two time periods. As expected, the areas with the greatest declines in water levels were also areas with the greatest irrigation-well densities (figs. 9, 11-12). Rises in water levels in northeastern Perkins and southeastern Keith Counties are likely the result of seepage from canals in the vicinity.

Increased utilization of the ground-water resources also has had a noticeable effect on the surface-water system in the study area. The perennial reaches of the streams in the study area were delineated based on seepage measurements made in the fall of 1952 (Lappala, 1978), the spring and fall of 1975 (Lappala, 1978), the fall of 1983 (U.S. Geological Survey, 1976-90), and the spring of 1989 (U.S. Geological Survey, 1976-90). Decreased seepage to streams from the High Plains aquifer shortened the perennial reaches of many of the streams in the study area by between 2 and 3 miles from 1975 to 1989 (fig. 14).

Another indication that seepage of ground water from the aquifer into streams decreased is the noticeable decline in base flow (table 6). The most substantial decreases appear to have occurred between 1975 and 1989. Base-flow values were measured during seepage runs or computed from daily flow values at gaging stations in the fall or early spring when runoff events are unusual. Average streamflows gener-ally also appear to have been smaller between 1975 and 1989 than between 1951 and 1975, as indicated by the streamflow data in table 7. It is important to note that there were no substantial differences in climatic conditions for those two periods.

\section{SIMULATION OF GROUND-WATER FLOW}

The movement of ground water in an anisotropic, heterogeneous aquifer can be described by a partial differential equation where the partial derivatives represent the movement of water in three dimensions. Analytical solutions of this equation are rarely possible, so several different numerical techniques commonly are used to obtain approximate solutions (McDonald and Harbaugh, 1988). One of these techniques involves subdividing the aquifer into a set of smaller blocks or cells of porous material and solving the finite-difference equation that describes flow through each cell. The resulting set of equations can be solved using several numerical techniques. For this study, the modular, three-dimensional, finitedifference, ground-water-flow model MODFLOW (McDonald and Harbaugh, 1988) was used to approximate the differential equation, and the strongly implicit procedure was used as the numerical solution technique. 


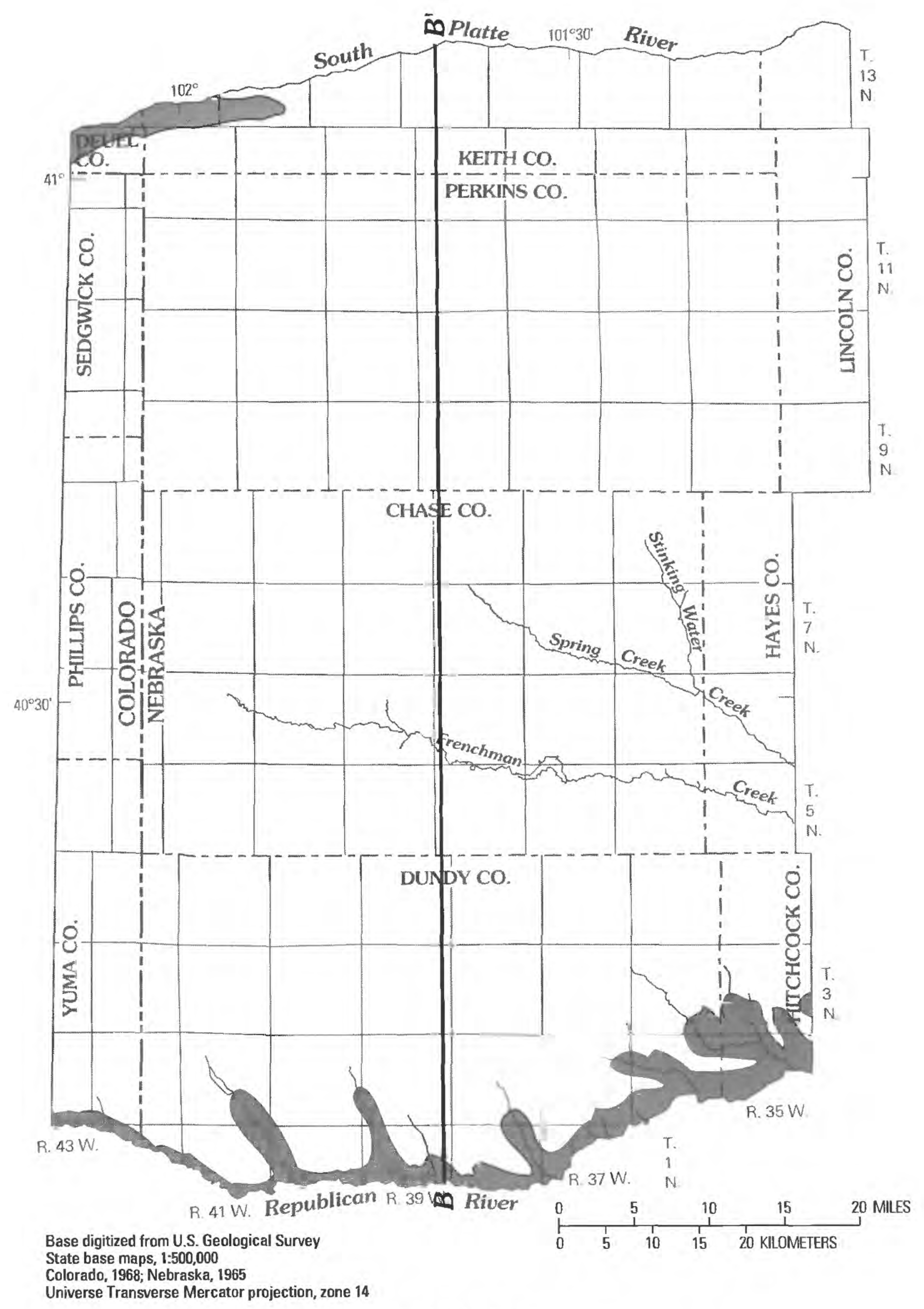

\section{EXPLANATION}

Area underlain by the Ogallala Formation

Area underlain by rocks other than the Ogallala Formation

$B-B^{\prime}$ Trace of geologic section-Shown in figure 5

Flgure 6. Lateral extent of the Ogallala Formation (Lappala, 1978; Eversoll and others, 1988) and trace of geologic section $B-B^{\prime}$ from Lappala (1978).

16 Simuiated Response of the High Pisins Aquifer to Ground-Wster Withdrswais, Upper Repubilcan Natural Resources District, Nebrsska 


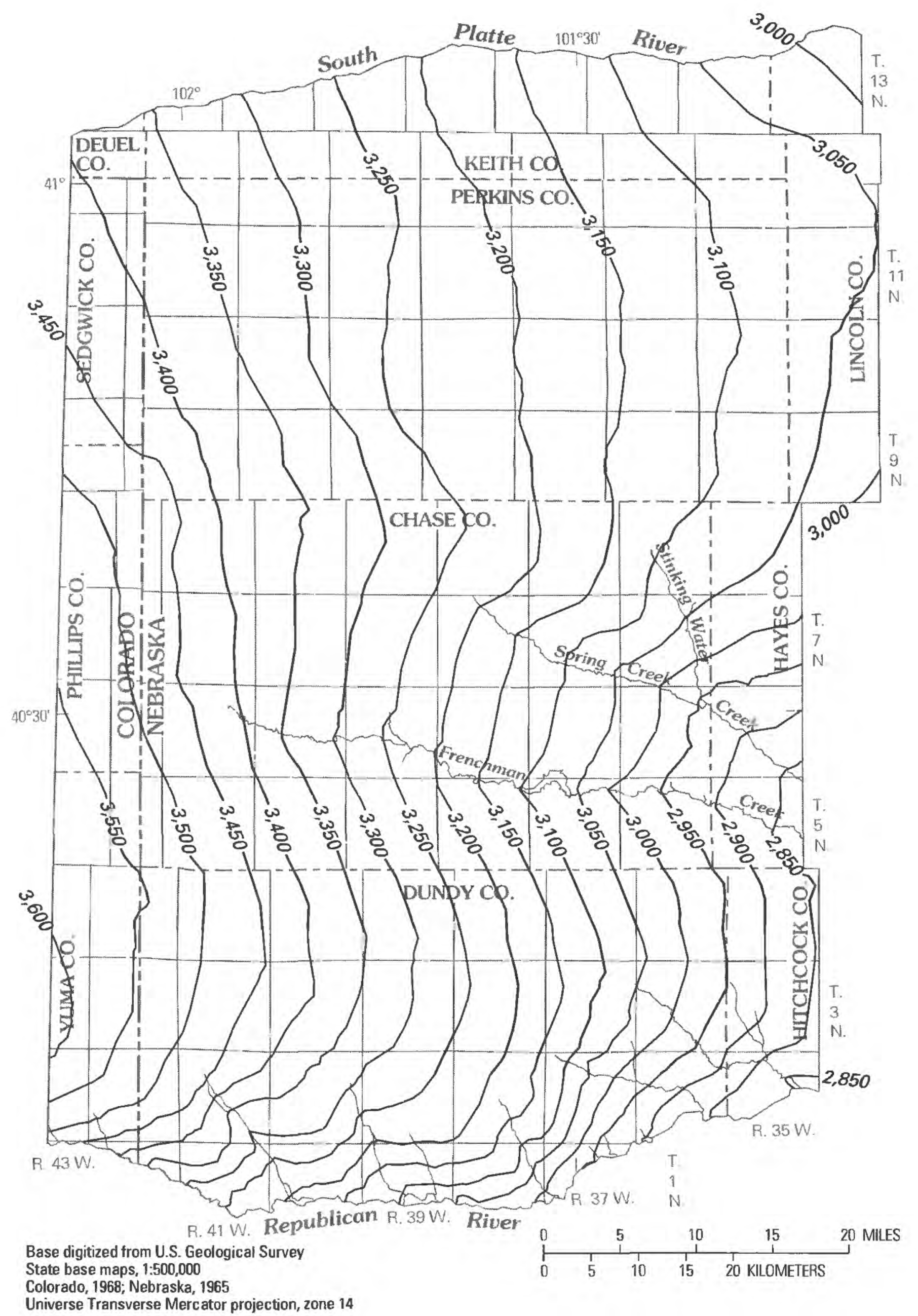

EXPLANATION

$-3,600$ - Water-table contour-Shows altitude

of water table, spring 1989. Datum is sea

level. Contour interval 50 feet

Figure 7. Water-table altitude in the High Plains aquifer, spring 1989. 


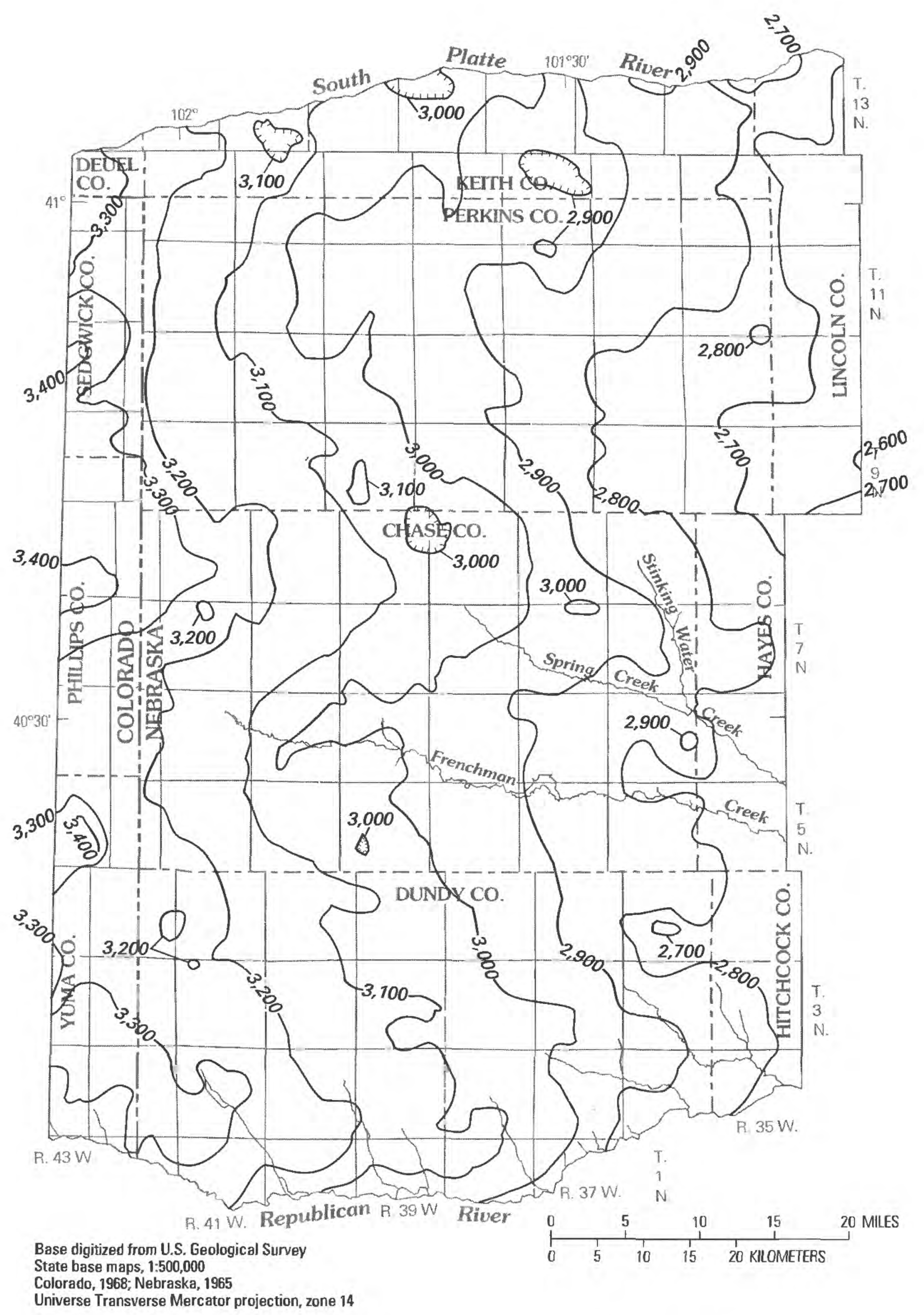

\section{EXPLANATION}

-2,900 - Base-of-aquifer contour-Shows altitude of the base of the High Plains aquifer. Datum is sea level. Contour interval 100 feet

Figure 8. Altitude of the base of the High Plains aquifer. 


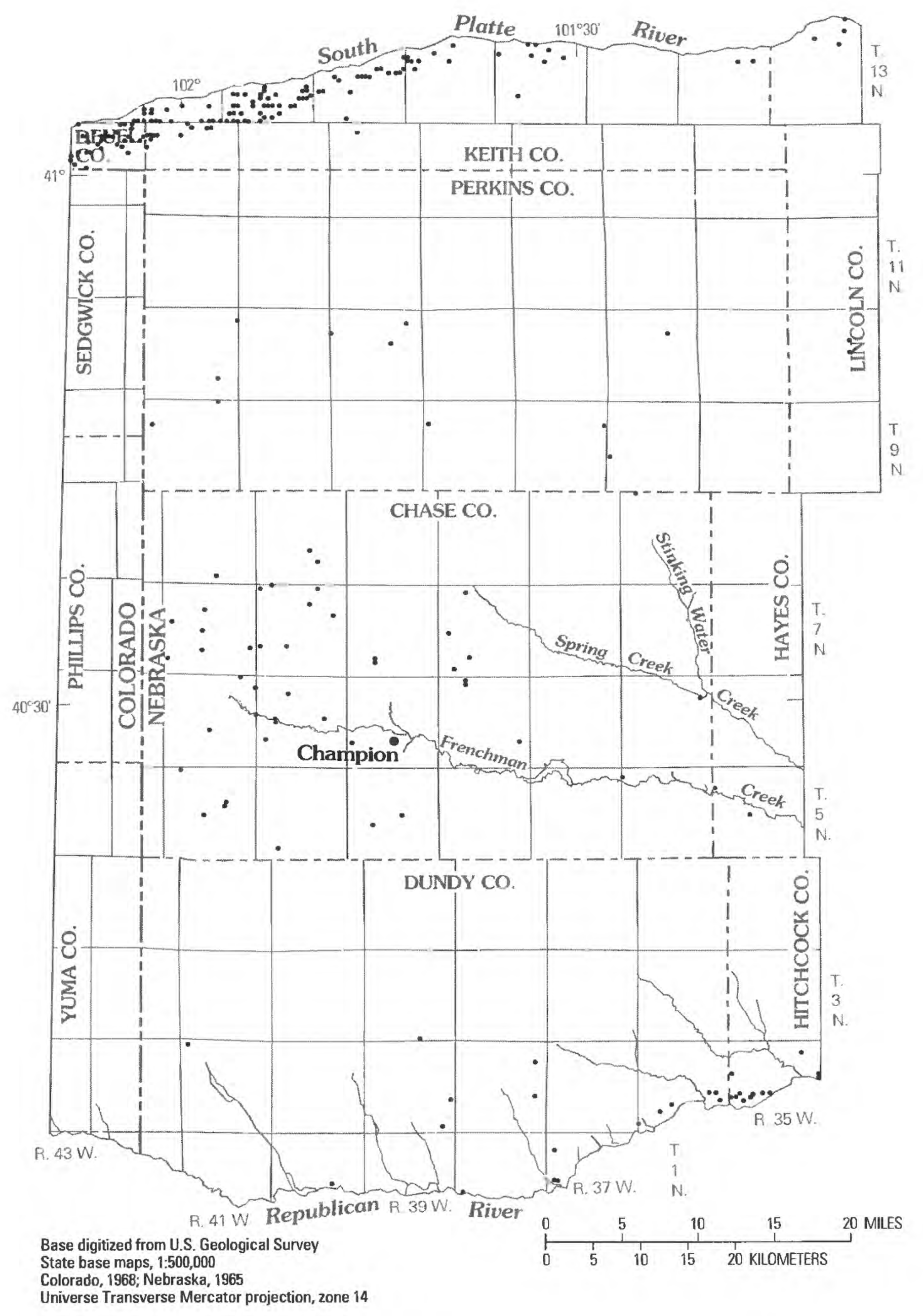

EXPLANATION

- Registered irrigation well

Figure 9. Location of registered wells in the Nebraska part of the study area drilled before 1952 (Susan France, Nebraska Department of Water Resources, written commun., 1990). 


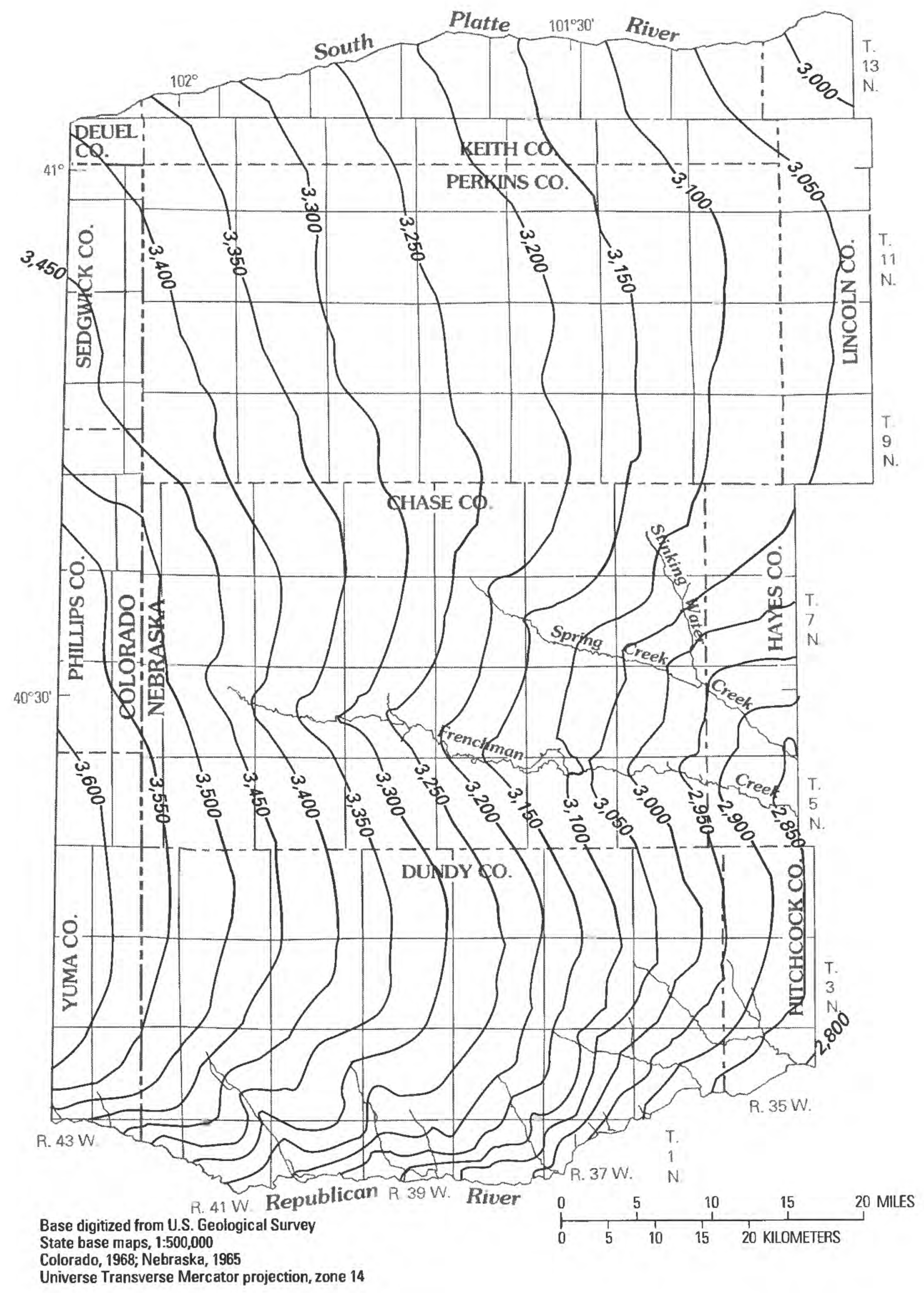

\section{EXPLANATION}

-3,100 - Estimated water-table contour-Shows altitude of water table, spring 1952. Datum is sea level. Contour interval 50 feet

Figure 10. Estimated water-table altitude in the High Plains aquifer, spring 1952 (modified from Lappala, 1978). 


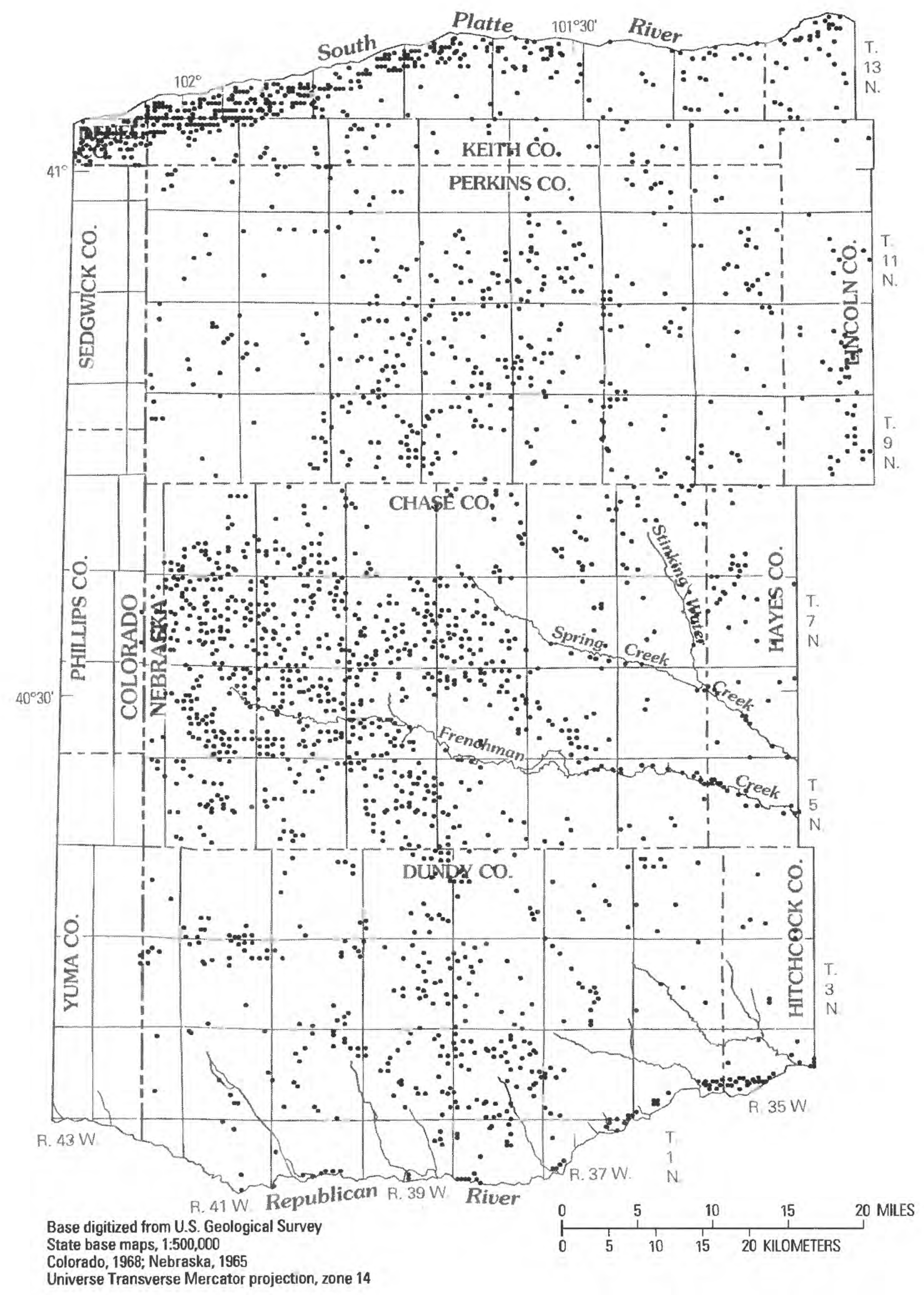

EXPLANATION

- Registered irrigation well

Figure 11. Location of registered wells in the Nebraska part of the study area drilled before 1975 (Susan France, Nebraska Department of Water Resources, written commun., 1990). 


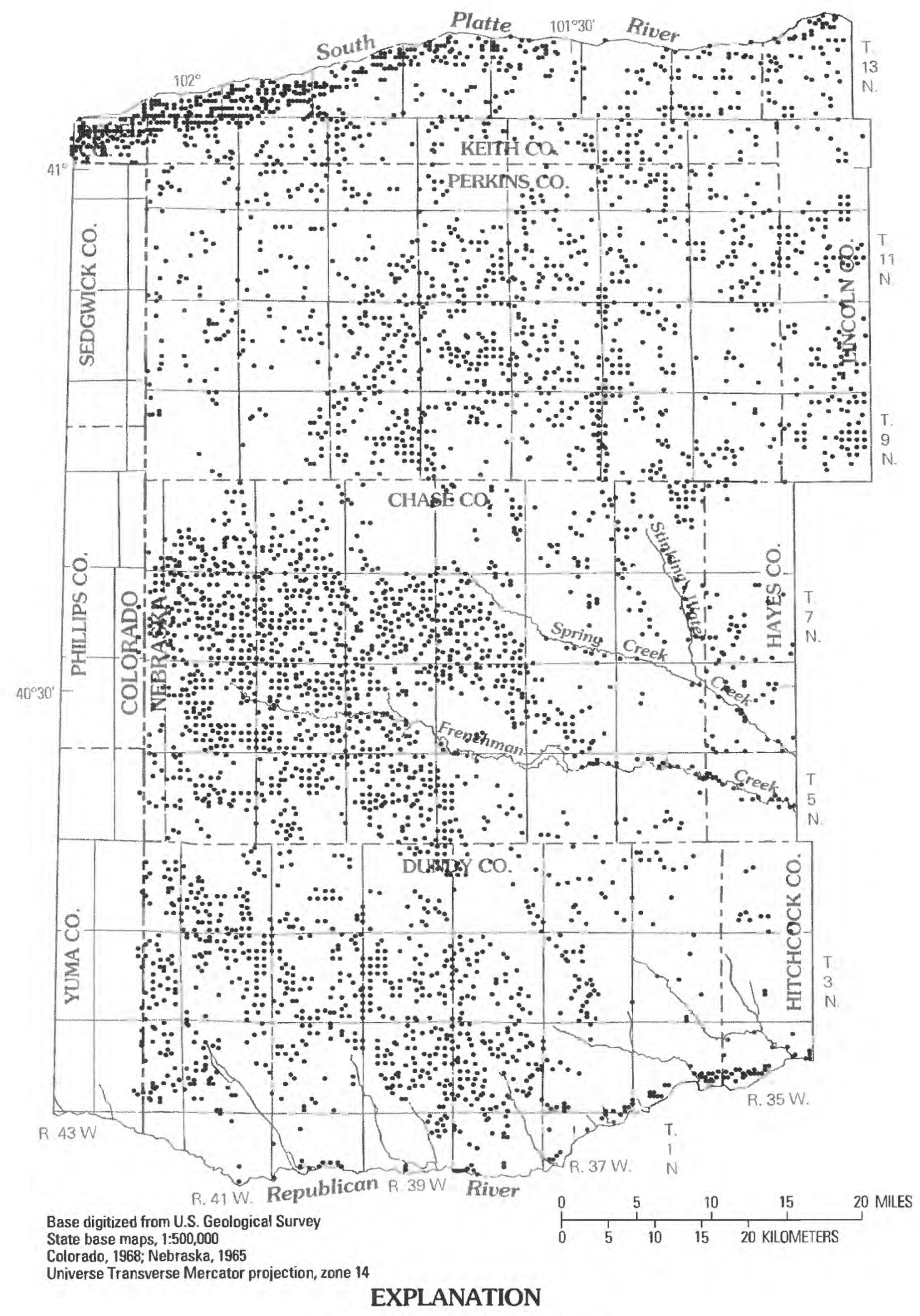

- Registered irrigation well

Figure 12. Location of registered wells in the Nebraska part of the study area drilled before 1989 (Susan France, Nebraska Department of Water Resources, written commun., 1990). 


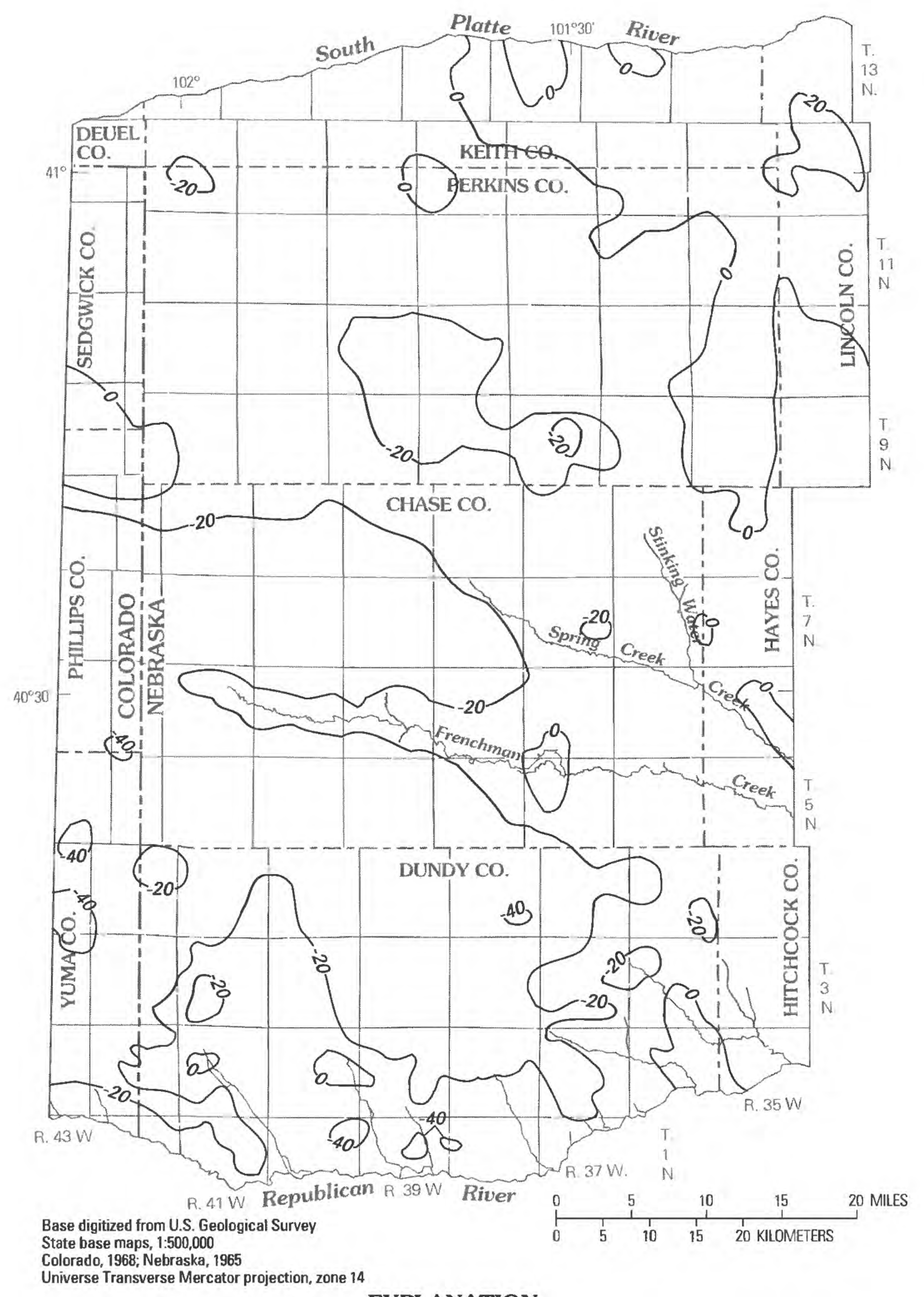

\section{EXPLANATION}

$-20-$ Line of equal water-level change-Negative $(-)$

value indicates water-level decline. Positive

value indicates water-level rise. Interval

20 feet

Figure 13. Water-level changes in the High Plains aquifer, 1952-89. 


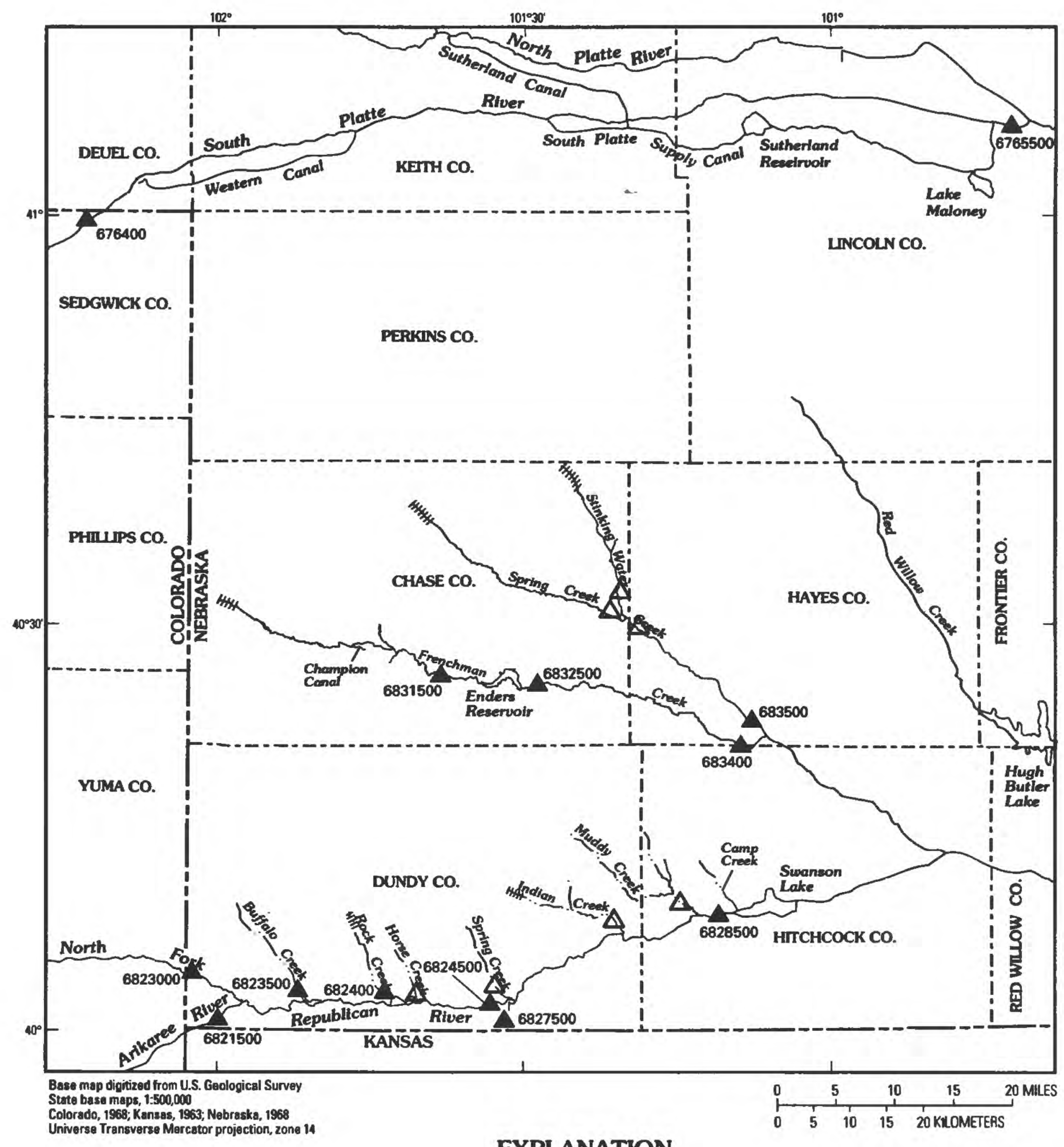

EXPLANATION

HWm+ Perennial reach in 1975 only

- Perennial reach in 1975 and 1989

$\triangle$ Seepage-measurement site-Listed in table 6 or table 12

6832500 Streamflow-gaging station and number-

Listed in tables 6,7 , and 12

Figure 14. Perennial reaches of streams in 1975 and 1989 and location of seepage-measurement sites and streamflowgaging stations [based on data from Lappala (1978) and U.S. Geological Survey (1990)].

24 Simulated Reaponse of the High Plaina Aquifer to Ground-Water Withdrawals, Upper Republican Natural Resources District, Nebraska 
Table 6. Base flow in 1952, 1975, and 1989 at selected seepage-measurement sites

$[--$, not measured $]$

\begin{tabular}{|c|c|c|c|}
\hline \multirow{2}{*}{$\begin{array}{l}\text { Site name and } \\
\text { streamflow-gaging } \\
\text { station number } \\
\text { (fig. 14) }\end{array}$} & \multicolumn{3}{|c|}{ Measured base flow, in cubic feet per second } \\
\hline & $\begin{array}{c}\text { Fall } 1952 \\
\text { (Lappala, 1978) }\end{array}$ & $\begin{array}{l}\text { Spring } 1975 \\
\text { (Lappala, 1978) }\end{array}$ & Spring 1989 \\
\hline $\begin{array}{l}\text { Frenchman Creek near } \\
\text { Imperial }(6831500)\end{array}$ & 66 & 53 & 26.4 \\
\hline $\begin{array}{l}\text { Frenchman Creek near } \\
\text { Enders }(6832500)\end{array}$ & -- & -- & .3 \\
\hline $\begin{array}{l}\text { Stinking Water Creek } \\
\text { near Wauneta (includes } \\
\text { Spring Creek in Chase } \\
\text { County) }\end{array}$ & 21 & 19 & 20.1 \\
\hline $\begin{array}{l}\text { Buffalo Creek near } \\
\text { Haigler }(6823500)\end{array}$ & 11 & 9 & 6.4 \\
\hline $\begin{array}{l}\text { Rock Creek at Parks } \\
(682400)\end{array}$ & 15 & 14 & 11.2 \\
\hline $\begin{array}{l}\text { Horse Creek near } \\
\text { Parks }{ }^{1}\end{array}$ & -- & .1 & .6 \\
\hline $\begin{array}{l}\text { Spring Creek near } \\
\text { Benkelman }{ }^{1}\end{array}$ & - & .6 & .2 \\
\hline Indian Creek near Max 1 & - & 4 & 3.7 \\
\hline $\begin{array}{l}\text { Muddy Creek near } \\
\text { Republican River }\end{array}$ & -- & - & 1.7 \\
\hline
\end{tabular}

${ }^{1}$ Active streamflow-gaging station not present at this site.

\section{Model Construction}

The High Plains aquifer was modeled using a 1-layer, regularly spaced grid consisting of 79 rows and 54 columns (fig. 15). Each row and column represents a 1-mile-wide strip of aquifer, so each cell represents 1 square mile of the aquifer. Of the 4,266 cells, 3,638 were active. The active model-area boundary coincides with the boundary of the study area. It was assumed, on the basis of results from previous investigations (Lappala, 1978), that there is no regional anisotropy of transmissivity within the aquifer; therefore, the grid was oriented north to south for convenience (fig. 15).

\section{Boundary Conditions}

Boundary conditions for the ground-water-flow model were chosen to reasonably represent hydrologic conditions at the study-area boundary. Boundary types used in the model were either no flow, constant head, general head, or variable head.
The upper boundary of the model is the water table in the High Plains aquifer, which is simulated as a variable-head surface. The lower boundary of the model is the base of the High Plains aquifer because the underlying units are relatively impermeable (Cardwell and Jenkins, 1963, p. 24). The base of the aquifer was simulated as a no-flow boundary.

The lateral boundary conditions are shown in figure 16. Cells along the southern and northern edges of the model area simulate the hydraulic connection between the aquifer and the South Platte, Republican, or North Fork of the Republican Rivers. These cells are designated as constant head, meaning that water levels in these cells were held constant at a specified level throughout the simulations. Constant-head cells were used only to simulate streams regulated by upstream reservoirs. This boundary condition is similar to the actual hydrologic conditions in these areas where the river is connected directly to the aquifer and maintains the head in the aquifer at a near constant level. The constant-head values were selected based on water-table altitudes near the rivers. 
Table 7. Average streamflow at gaging stations within and near the study area, 1951-89

\begin{tabular}{|c|c|c|c|c|c|c|}
\hline \multirow{3}{*}{$\begin{array}{l}\text { Station name and } \\
\text { number } \\
\text { (fig. 14) }\end{array}$} & \multicolumn{6}{|c|}{ Average streamflows during pumping and nonpumping periods (acre-feet per year) } \\
\hline & \multicolumn{2}{|c|}{$1951-75$} & \multicolumn{2}{|c|}{$1975-89$} & \multicolumn{2}{|c|}{$1951-89$} \\
\hline & Pumping $^{1}$ & Nonpumping $^{2}$ & Pumping $^{1}$ & Nonpumping $^{2}$ & Pumping $^{1}$ & Nonpumping $^{2}$ \\
\hline $\begin{array}{l}\text { South Platte River at } \\
\text { Julesburg, Colo. } \\
(6764000)\end{array}$ & 93,873 & 260,217 & 180,824 & 460,135 & 127,316 & 332,821 \\
\hline $\begin{array}{l}\text { South Platte River at } \\
\text { North Platte, Nebr. } \\
\text { (6765500) }\end{array}$ & 76,525 & 157,310 & 163,998 & 327,941 & 110,169 & 219,278 \\
\hline $\begin{array}{l}\text { Frenchman Creek near } \\
\text { Imperial }(6831500)\end{array}$ & 11,908 & 36,836 & 5,374 & 17,838 & 9,395 & 29,936 \\
\hline $\begin{array}{l}\text { Frenchman Creek near } \\
\text { Enders }(6832500)\end{array}$ & 28,852 & 17,551 & 23,184 & 1,029 & 26,672 & 11,551 \\
\hline $\begin{array}{l}\text { Frenchman Creek at } \\
\text { Palisade }(683400)\end{array}$ & 31,495 & 33,467 & 24,709 & 16,018 & 28,885 & 27,130 \\
\hline $\begin{array}{l}\text { Stinking Water Creek } \\
\text { near Palisade } \\
(683500)\end{array}$ & 7,693 & 23,550 & 4,845 & 16,521 & 6,597 & 20,997 \\
\hline $\begin{array}{l}\text { Arikaree River at } \\
\text { Haigler }(6821500)\end{array}$ & 5,322 & 9,796 & 1,908 & 5,473 & 4,009 & 8,226 \\
\hline $\begin{array}{l}\text { North Fork Republican } \\
\text { River at Colorado- } \\
\text { Nebraska stateline } \\
(6823000)\end{array}$ & 5,008 & 30,086 & 3,163 & 25,483 & 4,298 & 28,414 \\
\hline $\begin{array}{l}\text { Buffalo Creek near } \\
\text { Haigler }(6823500)\end{array}$ & 700 & 4,523 & 366 & 3,808 & 572 & 4,263 \\
\hline $\begin{array}{l}\text { Rock Creek at Parks } \\
\quad(682400)\end{array}$ & 2,416 & 7,779 & 2,010 & 6,587 & 2,260 & 7,346 \\
\hline $\begin{array}{l}\text { Republican River at } \\
\text { Benkelman } \\
(6824500)\end{array}$ & 12,399 & 53,057 & 6,636 & 42,258 & 10,182 & 49,135 \\
\hline $\begin{array}{l}\text { South Fork Republican } \\
\text { River near Benkel- } \\
\text { man }(6827500)\end{array}$ & 11,162 & 21,548 & 4,366 & 12,381 & 8,549 & 18,219 \\
\hline $\begin{array}{l}\text { Republican River at } \\
\text { Stratton }(6828500)\end{array}$ & 25,737 & 75,455 & 11,028 & 53,991 & 20,080 & 67,660 \\
\hline
\end{tabular}

No barriers to ground-water movement exist along the eastern and western edges of the study area; therefore, model boundaries in these areas were chosen to minimize the effects of the model boundaries on simulated water levels in the primary area of interest, the Upper Republican NRD. Flow into the aquifer along the western boundary was calculated to be 42,430 acre-feet in 1952 and 32,800 acre-feet in 1989 using the same equation as Lappala (1978): 
COLUMNS

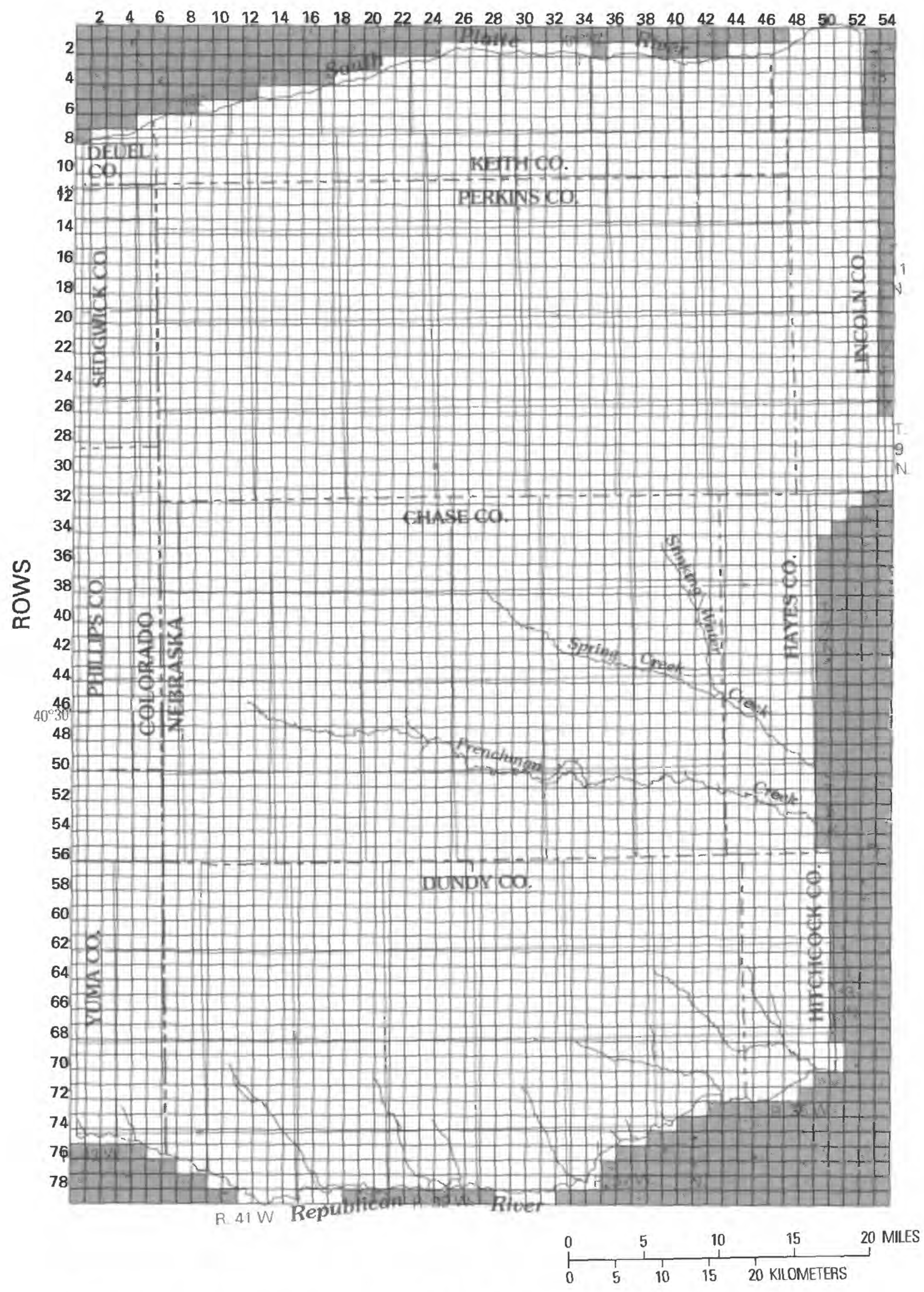

Base digitized from U.S. Geological Survey EXPLANATION

State base maps, 1:500,000

Colorado, 1968; Nebraska, 1965
Universe Transverse Mercator projection, zon⿺ 14 Active cell

Universe Transverse Mercar Nonactive cell

Figure 15. Finite-difference grid used in modeling ground-water flow in study area. 


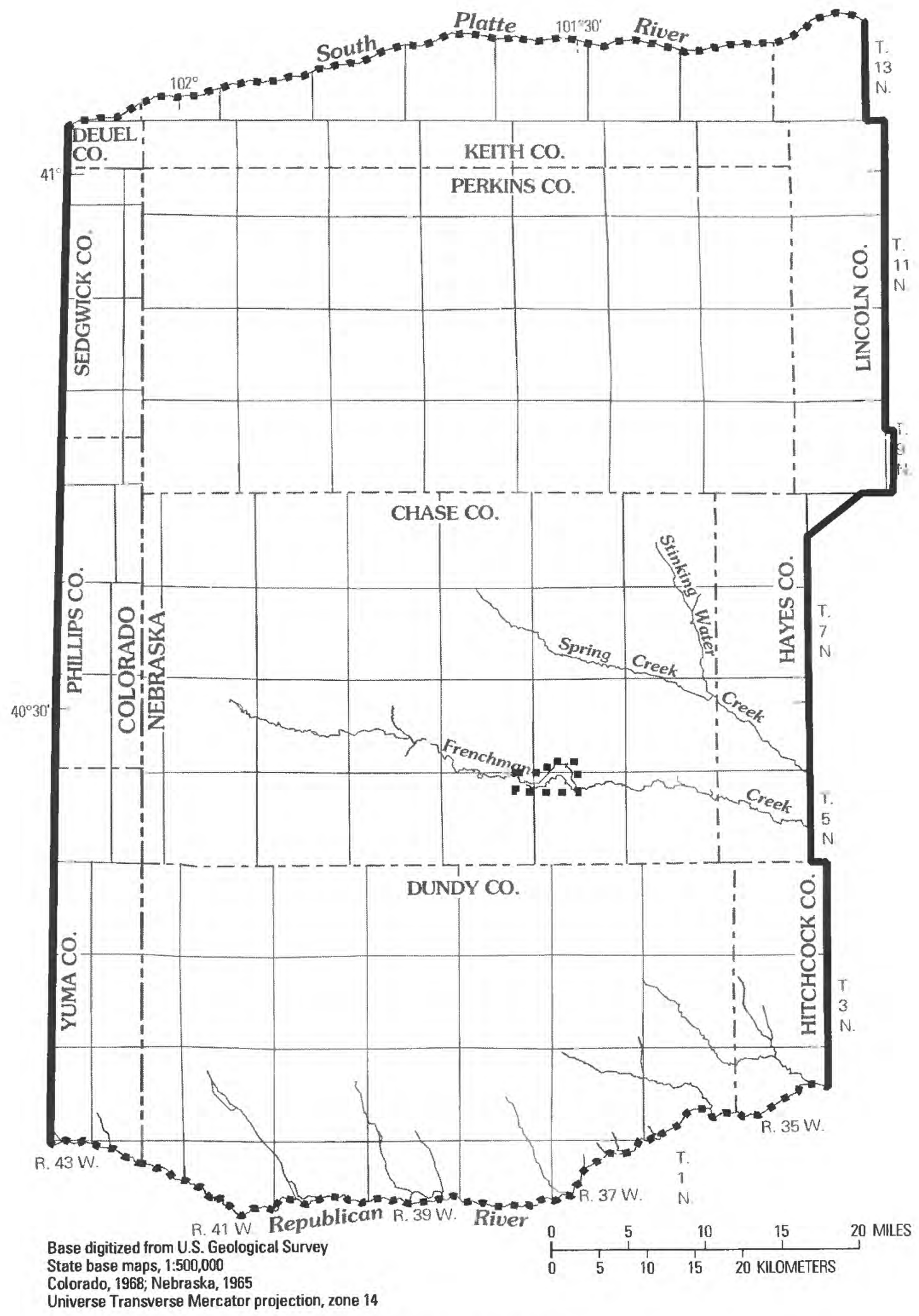

EXPLANATION

General-head boundary

..... - Constant-head boundary

Figure 16. Model-boundary conditions.

28 Simulated Response of the High Piains Aquifer to Ground-Water Withdrawais, Upper Repubiican Naturai Resources District, Nebraaka 


$$
Q=\sum_{i=1}^{m}-\hat{K}_{i} b_{i} w_{i}\left(\frac{\partial h}{\partial l}\right)_{i},
$$

where

$$
\begin{aligned}
Q \quad= & \text { flow into the study area }(+) \text { or flow } \\
& \text { out of the study area }(-)\left[\mathrm{L}^{3} / \mathrm{T}\right] ; \\
i & =\text { an index on the interval used; } \\
m \quad= & \text { total number of intervals; } \\
\hat{K}_{i} \quad= & \text { average hydraulic conductivity over } b_{i} \\
& \text { and } w_{i}[\mathrm{~L} / \mathrm{T}] ; \\
b_{i} \quad= & \text { average aquifer thickness over } \\
& \text { interval } \mathrm{i}[\mathrm{L}] \\
w_{i}= & \text { width of the increment } i[\mathrm{~L}] ; \text { and } \\
\left(\frac{\partial h}{\partial l}\right)_{i}= & \text { the hydraulic gradient normal to the } \\
& \text { boundary interval } i \text { [dimensionless]. }
\end{aligned}
$$

Flow out of the study area along the eastern edge was calculated to be 52,750 acre-feet in 1952, and 50,130 acre-feet in 1989 using the same equation. Cells along the eastern and western edges of the study area were designated general-head boundary cells, which means that the rate of flow into or out of these cells is proportional to the difference between the hydraulic head in the cell and the hydraulic head assigned to an external source of water, in this case those parts of the aquifer outside, but immediately adjacent to, the study area. Flow into a cell at a general-head boundary is calculated as follows:

$$
Q_{b}=C_{b}\left(h_{b}-h\right) \text {, }
$$

where $Q_{b}=$ flow into the cell from an external source $\left[\mathrm{L}^{3} / \mathrm{T}\right]$;

$C_{b}=$ conductance between the external source and the cell $\left[\mathrm{L}^{2} / \mathrm{T}\right]$;

$h_{b} \quad=$ hydraulic head assigned to external source [L]; and

$$
h \quad=\text { hydraulic head in the cell [L]. }
$$

Because water levels in the aquifer outside the study area change through time, it was necessary during the simulation to change the hydraulic-head values assigned to the external sources of general-head boundary cells. For this purpose, the entire simulation period was divided into five simulation intervals, and revised external head values were assigned for each general-head boundary cell at the beginning of each simulation interval (table 8 ). Conductance values $\left(C_{b}\right)$ were calculated for each of the general-head boundary cells for each simulation period using the formula:

$$
C_{b}=\frac{K A}{l},
$$

where $C_{b}=$ conductance between the external source and the cell $\left[\mathrm{L}^{2} / \mathrm{T}\right]$;

$K \quad=$ hydraulic conductivity $[\mathrm{L} / \mathrm{T}]$;

$A \quad=$ cross-sectional area of flow $\left[\mathrm{L}^{2}\right]$; and

$l \quad=$ length of flow path [L].

\section{Hydraulic Properties}

The hydraulic properties of the aquifer in the study area were estimated from the analysis of 149 test-hole and 1,174 irrigation-well logs, which represent more than one-third of the irrigation wells in the study area. The location of the test holes and irrigation wells is shown in figure 17. Hydraulic properties estimated from these logs include hydraulic conductivity and specific jield. The hydraulic conductivity and specific yield of the aquifer were calculated using data from table 9, which was modified from Peckenpaugh and Dugan (1983, p. 41 and 98). For each lithologic unit noted on the test-hole and irrigation-well logs, hydraulic-conductivity $(\mathrm{K})$ and specific-yield (Sy) values from table 9 were assigned

Table 8. Simulation time intervals during which external hydraulic-head values assigned to general-head boundary cells remained the same

\begin{tabular}{ccl}
\hline Simulation period & Time interval & \multicolumn{1}{c}{ Data year $^{1}$} \\
\hline 1 & $1952-63$ & 1952 \\
2 & $1964-73$ & 1964, interpolated \\
3 & $1974-80$ & 1975 \\
4 & $1981-87$ & 1982, interpolated \\
5 & $1988-89$ & 1989 \\
\hline
\end{tabular}

\footnotetext{
${ }^{1}$ Year for which assigned external hydraulic-head values are selected to represent given time interval.
} 


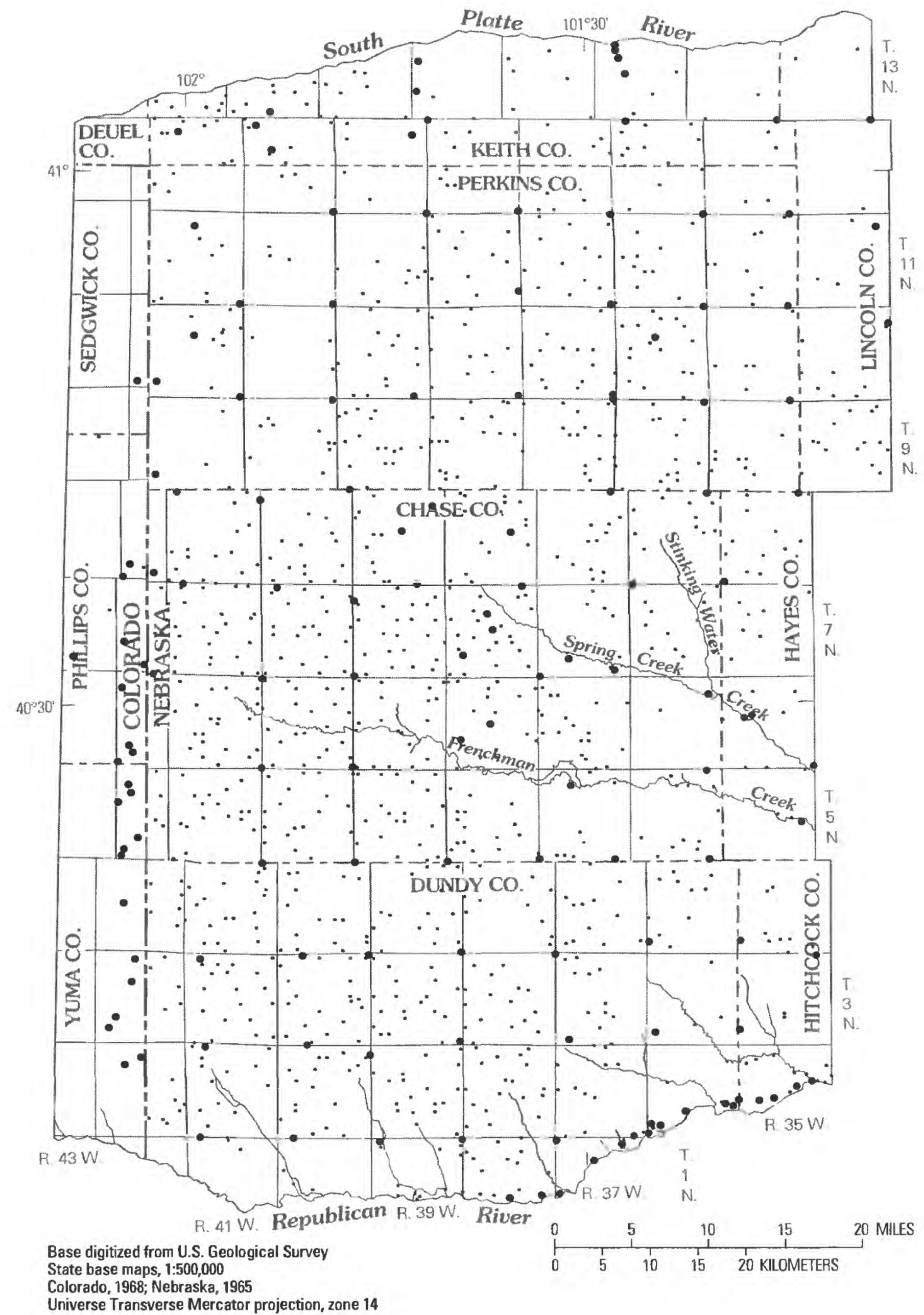

\section{EXPLANATION}

- Test hole

- Irrigation well

Figure 17. Location of test holes and irrigation wells from which data were used to estimate aquifer properties. 
Table 9. Hydraulic conductivity and specific yield estimated from description of materials comprising a lithologic unit (modified from Peckenpaugh and Dugan, 1983)

$[-$, not estimated $]$

\begin{tabular}{|c|c|c|c|c|c|c|c|}
\hline \multirow{3}{*}{$\begin{array}{c}\text { Grain-size class or range from } \\
\text { sample description }\end{array}$} & \multicolumn{6}{|c|}{ Hydraullc conductlvity, in feet per day } & \multirow{3}{*}{$\begin{array}{c}\text { Specific } \\
\text { yleld }^{2} \\
\text { (percent) }\end{array}$} \\
\hline & \multicolumn{3}{|c|}{$\begin{array}{c}\text { Estlmated from degree of } \\
\text { sorting }\end{array}$} & \multicolumn{3}{|c|}{ EstImated from silt content } & \\
\hline & Poor & Moderate & Well & Slight & Moderate & Large & \\
\hline \multicolumn{8}{|l|}{ FINE-GRAINED MATERIALS: } \\
\hline Clay & - & - & -- & 2.0 & -- & -- & 2.0 \\
\hline Silt, slightly clayey & - & - & - & 18 & - & -- & 17.0 \\
\hline Silt, moderately clayey & - & - & -- & 11 & -- & - & 11 \\
\hline Silt, very clayey & -- & -- & -- & 7.0 & -- & -- & 7.0 \\
\hline Silt; loess; sandy silt & - & - & -- & 20 & - & -- & 24.0 \\
\hline \multicolumn{8}{|l|}{ SANDS AND GRAVELS ${ }^{3}$ : } \\
\hline Very fine sand & 13 & 20 & 27 & 23 & 19 & 13 & 21.0 \\
\hline Very fine to fine sand & 27 & 27 & -- & 24 & 20 & 13 & 21.5 \\
\hline Very fine to medium sand & 36 & $41-47$ & -- & 32 & 27 & 21 & 22.4 \\
\hline Very fine to coarse sand & 48 & -- & -- & 40 & 31 & 24 & 22.5 \\
\hline Very fine to very coarse sand & 59 & - & -- & 51 & 40 & 29 & 22.4 \\
\hline Very fine sand to fine gravel & 76 & -- & - & 67 & 52 & 38 & 22.3 \\
\hline Very fine sand to medium gravel & 99 & -- & -- & 80 & 66 & 49 & 22.2 \\
\hline Very fine sand to coarse gravel & 128 & - & - & 107 & 86 & 64 & 22.1 \\
\hline Fine sand & 27 & 40 & 53 & 33 & 27 & 20 & 22.0 \\
\hline Fine to medium sand & 53 & 67 & - & 48 & 39 & 30 & 24.5 \\
\hline Fine to coarse sand & 57 & $67-72$ & - & 53 & 43 & 32 & 25.0 \\
\hline Fine to very coarse sand & 70 & - & - & 60 & 47 & 35 & 24.5 \\
\hline Fine sand to fine gravel & 88 & - & - & 74 & 59 & 44 & 24.4 \\
\hline Fine sand to medium gravel & 114 & -- & - & 94 & 75 & 57 & 24.3 \\
\hline Fine sand to coarse gravel & 145 & - & - & 107 & 87 & 72 & 24.2 \\
\hline Medium sand & 67 & 80 & 94 & 64 & 51 & 40 & 27.0 \\
\hline Medium to coarse sand & 74 & 94 & - & 72 & 57 & 42 & 27.5 \\
\hline Medium to very coarse sand & 84 & $98-111$ & - & 71 & 61 & 49 & 27.4 \\
\hline Medium sand to fine gravel & 103 & -- & - & 84 & 68 & 52 & 27.3 \\
\hline Medium sand to medium gravel & 131 & - & -- & 114 & 82 & 66 & 27.2 \\
\hline Medium sand to coarse gravel & 164 & - & - & 134 & 108 & 82 & 27.1 \\
\hline Coarse sand & 80 & 107 & 134 & 94 & 74 & 53 & 28.0 \\
\hline Coarse to very coarse sand & 94 & 134 & - & 94 & 75 & 57 & 27.5 \\
\hline Coarse sand to fine gravel & 116 & $136-156$ & -- & 107 & 88 & 68 & 27.3 \\
\hline Coarse sand to medium gravel & 147 & -- & -- & 114 & 94 & 74 & 27.1 \\
\hline Coarse sand to coarse gravel & 184 & -- & -- & 134 & 100 & 92 & 26.8 \\
\hline Very coarse sand & 107 & 147 & 187 & 114 & 94 & 74 & 27.0 \\
\hline Very coarse sand to fine gravel & 134 & 214 & -- & 120 & 104 & 87 & 26.5 \\
\hline Very coarse sand to medium gravel & 170 & $199-227$ & - & 147 & 123 & 99 & 26.3 \\
\hline Very coarse sand to coarse gravel & 207 & -- & - & 160 & 132 & 104 & 25.8 \\
\hline Fine gravel & 160 & 214 & 267 & 227 & 140 & 107 & 26.0 \\
\hline Fine to medium gravel & 201 & 334 & -- & 201 & 167 & 134 & 25.5 \\
\hline Fine to coarse gravel & 245 & $289-334$ & - & 234 & 189 & 144 & 24.5 \\
\hline Medium gravel & 241 & 321 & 401 & 241 & 201 & 160 & 25.0 \\
\hline Medium to coarse gravel & 294 & 468 & - & 294 & 243 & 191 & 24.0 \\
\hline Coarse gravel & 334 & 468 & 602 & 334 & 284 & 234 & 23.0 \\
\hline
\end{tabular}

${ }^{1}$ Hydraulic-conductivity values are from an unpublished, undated paper by E.C. Reed and R. Piskin, Conservation and Survey Division, University of Nebraska, Lincoln.

${ }^{2}$ Specific-yield values are modified from Johnson (1967).

${ }^{3}$ Reduce hydraulic conductivity by 10 percent if grains are subangular. 
according to grain size of the material composing the unit and the degree of sorting or silt content of the unit. A thickness-weighted average value of hydraulic conductivity and specific yield then was calculated for each test hole or irrigation well.

\section{Hydraulic Conductivity}

The distribution of hydraulic conductivity used in the model is shown in figure 18. Hydraulicconductivity values for individual test holes or wells were averaged by quarter township throughout the study area because of the extreme variability of these values within short distances. A model array of hydraulic-conductivity values was generated by assigning the average value for each quarter township to cells representing that quarter township in the model. Hydraulic-conductivity values assigned in areas with little or no test-hole or well data were based on data from Lappala's (1978) model. Assigned hydraulic-conductivity values ranged from 20 to 155 feet per day and most commonly ranged from 50 to 75 feet per day.

\section{Specific Yield}

The distribution of specific yield used in the model is shown in figure 19. Specific-yield values for individual test holes or wells also were averaged, just as hydraulic-conductivity values were, by quarter township throughout the study area. Assigned specific-yield values ranged from 0.09 to 0.22 and were most commonly from 0.15 to 0.20 .

\section{Stresses on the Aquifer System}

The most significant stresses on the High Plains aquifer in the study area are well pumpage, recharge from precipitation, and interaction with streams and rivers. Evapotranspiration (ET) losses directly from a shallow water table were considered to be insignificant except in the valley bottoms near major streams where the stream supplies most of the loss. Therefore, direct ET losses do not affect the aquifer appreciably and were not considered in the model. Data on the locations and magnitudes of the most substantial stresses on the aquifer were not available for the study area for the entire transient calibration period, 1952-89. The following sections describe how the magnitude of these stresses was estimated and how these stresses were simulated in the model.

\section{Recharge and Pumpage}

Recharge and pumpage used in the groundwater-flow model were estimated using two computer programs referred to herein as the PET and the soilwater programs. These programs are documented in Cady and Peckenpaugh (1985), and earlier program versions have been used in other studies by Lappala (1978), Peckenpaugh and Dugan (1983), Peckenpaugh and others (1987), and Goeke and others (1992) to make similar estimates.

These programs were used to estimate recharge and pumpage because these stresses had not been measured for the entire period of interest in the entire study area. Also, using measured pumpage data would not account for excess water that is pumped but not transpired or evaporated and, therefore, recharges the aquifer. These programs account for this excess by estimating water used by crops or evaporated and thus lost from the hydrogeologic system. These estimates are used instead of metered pumpage values, which are larger.

The PET program estimates potential ET using the Jensen-Haise method (Jensen and others, 1970) and climate data from 19 weather stations in or near the study area (table 10). Data needed for each station by the PET program include: (1) average monthly values for precipitation, air temperature, and percentage of possible sunshine, (2) the mean minimum and maximum air temperatures for the warmest month of the year (July), and (3) the mean daily solar-radiation values on cloudless days for each month. Results from the PET program consist of mean monthly precipitation, mean monthly air temperature, and monthly potential ET for the period of interest for each weather station. These data are used in the soil-water program.

The soil-water program estimates recharge to the water table and the consumptive irrigation requirement (CIR) of crops based on ET estimates from the PET program and data on soil characteristics, monthly precipitation, and crop characteristics. The CIR of a crop is the amount of supplemental water required by the crop to thrive and is defined to be equal to the amount of supplemental water required to maintain the root zone at 50 percent of its available water capacity. Data needed by the soil-water program include: (1) monthly potential ET calculated by the PET program; (2) monthly precipitation; and (3) several coefficients selected based on soil, crop, and topographic characteristics. A more detailed description of the data needed and coefficient selection can be found in Cady 


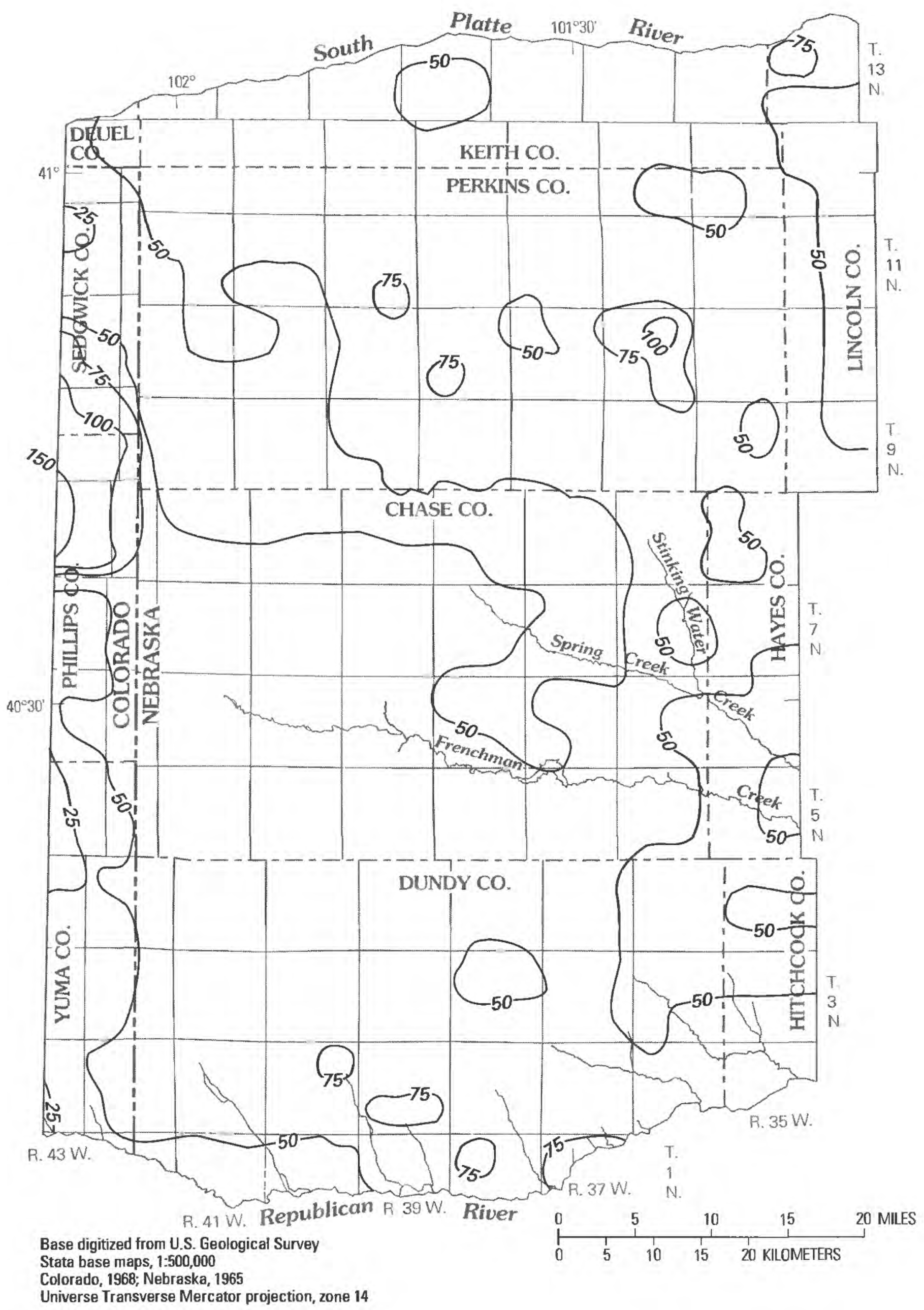

EXPLANATION

-20 - Line of equal hydraulic conductivity-Interval 25 feet per day

Figure 18. Distributiorı of hydraulic corıductivity irı the High Plairıs aquifer. 


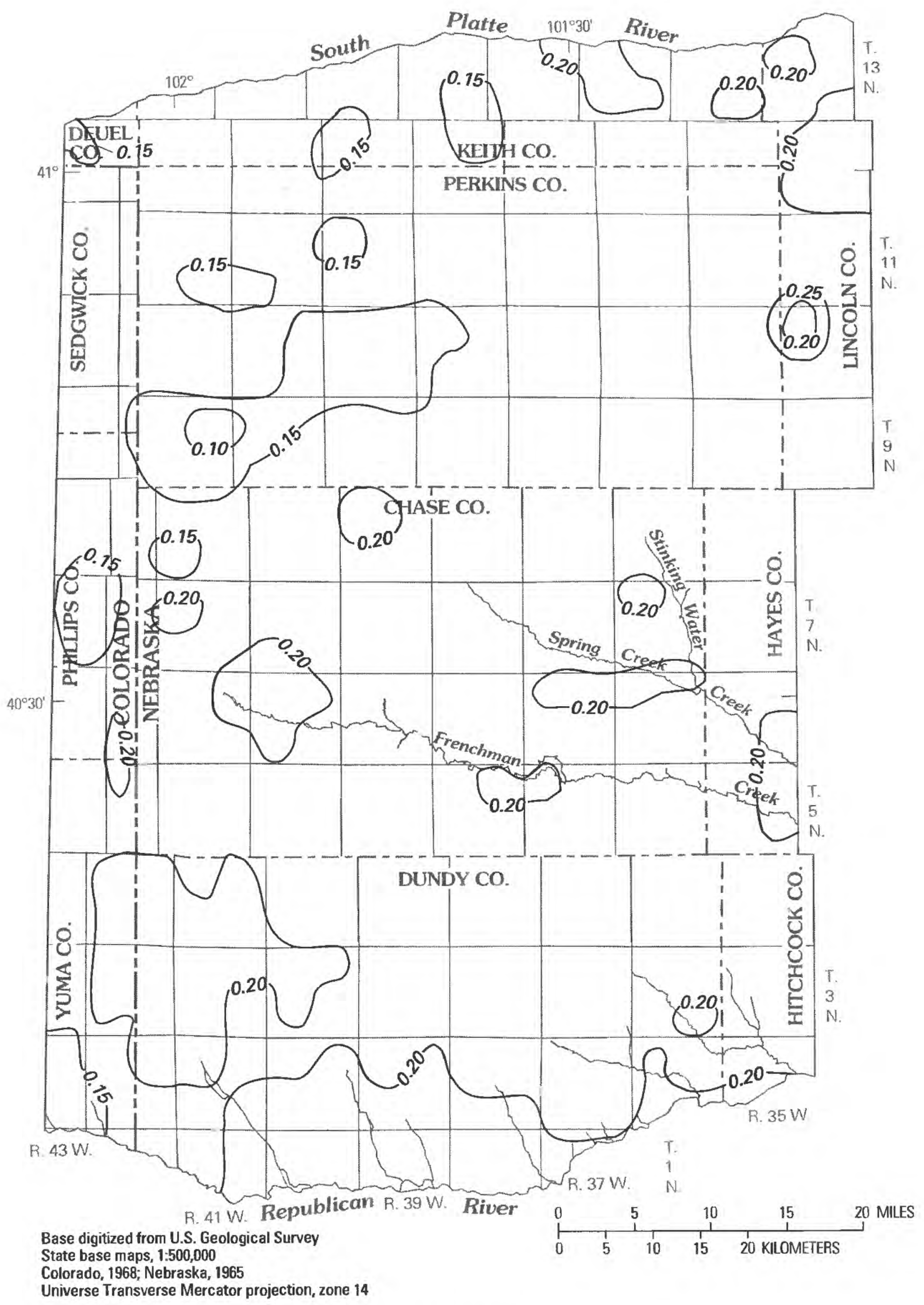

EXPLANATION

$-0.10-$ Line of equal specific yield—Interval 0.05

Figure 19. Distribution of specific yield in the High Plains aquifer. 
and Peckenpaugh (1985). Results from the soil-water program include the annual estimates of the following items for each soil group, land use, and weather station from 1951-89: infiltration, surface runoff, ET, irrigated land recharge, CIR, dryland recharge, and dryland water shortage. Table 11 lists output from the soilwater program for three selected weather stations.

Pumpage and recharge values were distributed in the model through time by dividing the simulation period into 111 intervals or stress periods, with each full year represented by three stress periodsJanuary-May, June-August, and SeptemberDecember. The first stress period simulated was JuneAugust 1952, and the last stress period simulated was January-May 1989. Pumpage and recharge values were assigned to designated cells for each stress period on the basis of soil and land-use characteristics and the number of irrigation wells in that cell for the time period being simulated. Average recharge values assigned to each cell from 1952 through 1988 using the MODFLOW recharge package are shown in figure 20. Pumpage in each cell for each stress period was calculated based on output from the soil-water program. For each cell the total pumpage was calculated by summing the pumpage for each crop in the cell, which was calculated by multiplying the CIR for the crop times the total number of acres of that crop in the cell. The CIR values for each crop were selected from soil-water program output based on the soil types in the cell, the proximity of the cell to the nearest weather stations, and the period of time being simulated. Pumpage values assigned to each cell for the June-August 1988 stress period using the MODFLOW well package are shown in figure 21 .

\section{Streams, Rivers, and Canals}

The South Platte, Republican, and North Fork of the Republican Rivers are lateral boundaries simulated as constant-head cells. Enders Reservoir also was simulated using constant-head cells. Other perennial streams and rivers and large irrigation canals were simulated in the model using the stream-routing package written by Prudic (1989) for use with

MODFLOW. According to Lappala (1978), the perennial streams in the study area are directly connected to the aquifer; therefore, streambed conductances were assigned equal to the aquifer conductance so that streambeds did not restrict flow. Cells that were used to simulate interior streams and rivers using the stream-routing package are shown in figure 22.
Streams, rivers, or canals that were simulated include the Western and Sutherland Canals; Stinking Water, Spring, and Frenchman Creeks in Chase County; and Buffalo, Rock, Horse, Spring, Indian, and Muddy Creeks in Dundy County.

\section{Model Calibration}

The model was calibrated under both steadystate and transient conditions to ensure that the final model adequately represented the response of the High Plains aquifer to stress. In general terms, calibration consisted of minor and reasonable adjustment of hydraulic characteristics, such as hydraulic conductivity, until a reasonable match was obtained between computed and observed water levels and streamflows. The following sections describe in more detail the calibration of the model under both steady-state and transient conditions.

\section{Steady-State Conditions}

The model was calibrated under steady-state conditions to simulate the flow system in the aquifer before extensive pumping for irrigation began. The model was calibrated under steady-state conditions by adjusting input data, including hydraulic conductivity, streamflows assigned to the upstream reach of each stream segment (Prudic, 1989), and boundary head and conductance at general-head boundary cells, so that the simulated spring 1952 water levels adequately matched the estimated spring 1952 water levels. These data were adjusted only by small percentages and only in certain areas. Data from spring 1952 were assumed to be reasonably representative of predevelopment water levels.

Two different recharge arrays were tested as fluxes for the steady-state simulations. One recharge array tested was the average recharge from 1952 through 1988, and the other recharge array tested was the average recharge from January 1 through May 31 , 1953. The latter recharge array was tested because it allowed climatic conditions prior to May 1953 to affect the recharge. This is because climatic conditions in 1952 determined the available soil water at the beginning of the January 1 through May 31, 1953, recharge period. Pumpage was not used in the steadystate simulations because these simulations were designed to represent predevelopment conditions.

Both of the steady-state recharge arrays produced a root mean square error (RMSE) of approx- 
Table 10. Average annual precipitation for weather stations in and near the study area, 1951-89 [data from National Oceanic and Atmospheric Administration, 1951-89]

\begin{tabular}{lc}
\hline $\begin{array}{c}\text { Weather station } \\
\text { (shown in figure 2, except as indicated) }\end{array}$ & $\begin{array}{c}\text { Average annuai precipitation from 1951-89 } \\
\text { (inches) }\end{array}$ \\
\hline Benkelman & 18.10 \\
Big Springs & 17.16 \\
Champion & 19.01 \\
Enders Lake & 18.74 \\
Haigler & 17.05 \\
& \\
Hayes Center & 19.95 \\
Imperial & 19.02 \\
Madrid & 19.10 \\
Ogallala & 17.79 \\
Palisade & 20.43 \\
& \\
Paxton & 17.66 \\
Stratton & 19.96 \\
Wallace $^{1}$ & 17.69 \\
Wauneta & 19.29 \\
Holyoke & 17.93 \\
& \\
Julesburg $^{1}$ & 17.09 \\
Wray $^{1}$ & 16.91 \\
St. Francis $^{1}$ & 17.16 \\
St. Francis-8 $^{1}$ & 17.27 \\
\hline
\end{tabular}

\footnotetext{
${ }^{1}$ Not shown in figure 2.
}

imately 30 feet using water levels for the 3,638 active cells within the study area. The RMSE's were calculated by summing the squared difference between the simulated and observed water levels for each active cell, by dividing this summation by the number of active cells (the 111 constant-head cells were not considered active cells) and then taking the square root of the result. The mean absolute error was 23.5 feet and the maximum absolute error was 80 feet. The standard deviation of the differences was 28.1 feet.

The size of the RMSE is assumed to have been the result of uncertainties related to the estimated 1952 water levels and the recharge arrays, which cannot adequately represent the historical fluxes that produced the spring 1952 water levels. Goeke and others (1992, p. 58) observed a RMSE of 157 feet for a modeled area immediately east of the study area because the simulated recharge could not adequately represent those that generated the steady-state water levels.

\section{Translent Conditions}

The model was calibrated under transient conditions by simulating the period from 1952 through 1989. Estimated spring 1952 water levels (fig. 10) were used as initial water levels, and computed 1989 water levels were compared with observed spring 1989 water levels. During calibration, adjustments were made in hydraulic conductivity, specific yield, pumpage, recharge, and the streamflows assigned to the upstream reach of each stream segment (Prudic, 1989). All values were adjusted within the ranges that were considered reasonable for the particular parameters as determined from previous studies (Cardwell and Jenkins, 1963; Lappala, 1978) and from other measured data for that parameter. The resultant computed 1989 water levels were compared against the observed 1989 water levels.

Four methods were used to assess the accuracy of the transient calibration of the model. The first 
Table 11. Output from soil-water program, given as annual averages, 1951-89, using data from the Haigler, Imperial, and Madrid weather stations

[I, infiltration; RO, surface runoff; ET, evapotranspiration; DPI, deep percolation (recharge) from irrigated lands; CIR, consumptive irrigation requirements; DPD, deep percolation (recharge) from drylands; STD, water shortage on drylands]

\begin{tabular}{|c|c|c|c|c|c|c|c|c|}
\hline \multirow[b]{2}{*}{ Soil series } & \multirow[b]{2}{*}{ Land use } & \multicolumn{7}{|c|}{ Annual average (inches) } \\
\hline & & $\mathbf{I}$ & RO & ET & DPI & CiR & DPD & STD \\
\hline \multicolumn{9}{|c|}{ Haigler (precipitation, 17.1 inches per year) } \\
\hline \multirow{6}{*}{$\begin{array}{l}\text { Rosebud, } \\
\text { Alliance, } \\
\text { Kuma, Goshen, } \\
\text { and Keith }\end{array}$} & Corn & 16.3 & 0.78 & 36.1 & 1.0 & 17.5 & 0.94 & 20.8 \\
\hline & Dry beans, grain sorghum & 16.3 & .78 & 31.8 & 2.1 & 16.5 & 1.9 & 17.4 \\
\hline & Winter wheat & 16.3 & .78 & 34.8 & .77 & 10.8 & .20 & 18.7 \\
\hline & Pasture, range & 16.8 & .24 & 37.2 & .30 & 16.9 & .27 & 20.6 \\
\hline & Fallow & 15.3 & 1.7 & 20.9 & 1.3 & 5.97 & 1.1 & 6.58 \\
\hline & Alfalfa & 16.8 & .24 & 42.4 & .16 & 17.5 & .12 & 25.7 \\
\hline \multirow{6}{*}{$\begin{array}{l}\text { Colby, Canyon, } \\
\text { and Ulysses }\end{array}$} & Corn & 15.0 & 2.1 & 36.1 & .62 & 18.4 & .56 & 21.7 \\
\hline & Dry beans, grain sorghum & 15.0 & 2.1 & 31.8 & 1.5 & 17.2 & 1.3 & 18.1 \\
\hline & Winter wheat & 15.0 & 2.1 & 34.8 & .45 & 11.4 & .06 & 19.9 \\
\hline & Pasture, range & 15.3 & 1.7 & 37.2 & .13 & 18.0 & .10 & 22.0 \\
\hline & Fallow & 15.0 & 2.1 & 20.9 & 1.0 & 6.16 & .82 & 6.72 \\
\hline & Alfalfa & 15.3 & 1.7 & 42.4 & .07 & 18.4 & .04 & 27.2 \\
\hline \multirow{6}{*}{$\begin{array}{l}\text { Bridget, } \\
\text { McCook, } \\
\text { Duroc, } \\
\text { Bankard, Las, } \\
\text { Glenburg }\end{array}$} & Corn & 16.3 & .78 & 36.1 & 1.2 & 17.5 & 1.1 & 20.9 \\
\hline & Dry beans, grain sorghum & 16.3 & .78 & 31.8 & 2.3 & 16.6 & 2.1 & 17.7 \\
\hline & Winter wheat & 16.3 & .78 & 34.8 & .79 & 10.6 & .24 & 18.7 \\
\hline & Pasture, range & 16.8 & .24 & 37.2 & .41 & 16.8 & .37 & 20.8 \\
\hline & Fallow & 16.3 & .78 & 20.9 & 1.9 & 5.59 & 1.7 & 6.27 \\
\hline & Alfalfa & 16.8 & .24 & 42.4 & .19 & 17.4 & .16 & 25.8 \\
\hline \multirow{6}{*}{$\begin{array}{l}\text { Jayem, Haxtun, } \\
\text { Rosebud, Keith }\end{array}$} & Corn & 16.3 & .78 & 36.1 & 1.3 & 17.5 & 1.3 & 21.1 \\
\hline & Dry beans, grain sorghum & 16.3 & .78 & 31.8 & 2.5 & 16.6 & 2.4 & 17.9 \\
\hline & Winter wheat & 16.3 & .78 & 34.8 & .85 & 10.3 & .32 & 18.8 \\
\hline & Pasture, range & 16.8 & .24 & 37.2 & .56 & 16.8 & .52 & 20.9 \\
\hline & Fallow & 16.3 & .78 & 20.9 & 2.1 & 5.65 & 1.9 & 6.49 \\
\hline & Alfalfa & 16.8 & .24 & 42.4 & .25 & 17.2 & .21 & 25.8 \\
\hline \multirow{6}{*}{$\begin{array}{l}\text { Valent, } \\
\text { Valentine, } \\
\text { Tassel }\end{array}$} & Corn & 16.8 & .24 & 36.1 & 2.6 & 17.5 & 2.5 & 21.8 \\
\hline & Dry beans, grain sorghum & 16.8 & .24 & 31.8 & 3.9 & 16.9 & 3.8 & 18.8 \\
\hline & Winter wheat & 16.8 & .24 & 34.8 & 1.5 & 9.20 & 1.2 & 19.1 \\
\hline & Pasture, range & 16.8 & .24 & 37.2 & 1.5 & 16.6 & 1.5 & 21.9 \\
\hline & Fallow & 16.3 & .78 & 20.9 & 3.0 & 5.84 & 2.9 & 7.53 \\
\hline & Alfalfa & 16.8 & .24 & 42.4 & .77 & 16.6 & .74 & 26.4 \\
\hline
\end{tabular}


Table 11. Output from soil-water program, given as annual averages, $1951-89$, using data from the Haigler, Imperial, and Madrid weather stations-Continued

\begin{tabular}{|c|c|c|c|c|c|c|c|c|}
\hline \multirow[b]{2}{*}{ Soil series } & \multirow[b]{2}{*}{ Land use } & \multicolumn{7}{|c|}{ Annual average (inches) } \\
\hline & & $\mathbf{I}$ & RO & ET & DPI & CIR & DPD & STD \\
\hline \multicolumn{9}{|c|}{ Imperial (precipitation, 19.0 inches per year) } \\
\hline \multirow{6}{*}{$\begin{array}{l}\text { Rosebud, } \\
\text { Alliance, } \\
\text { Kuma, Goshen, } \\
\text { Keith }\end{array}$} & Corn & 18.0 & 1.0 & 33.2 & 1.7 & 14.3 & 1.6 & 16.8 \\
\hline & Dry beans, grain sorghum & 18.0 & 1.0 & 29.3 & 3.4 & 13.8 & 3.1 & 14.4 \\
\hline & Winter wheat & 18.0 & 1.0 & 31.7 & 1.1 & 9.08 & .24 & 13.9 \\
\hline & Pasture, range & 18.7 & .32 & 34.2 & .72 & 13.6 & .61 & 16.1 \\
\hline & Fallow & 16.8 & 2.2 & 19.1 & 2.4 & 4.12 & 2.1 & 4.31 \\
\hline & Alfalfa & 18.7 & .32 & 38.9 & .27 & 14.6 & .19 & 20.4 \\
\hline \multirow{6}{*}{$\begin{array}{l}\text { Ulysses, Keith, } \\
\text { Colby }\end{array}$} & Corn & 16.4 & 2.6 & 33.2 & .95 & 15.3 & .86 & 17.7 \\
\hline & Dry beans, grain sorghum & 16.4 & 2.6 & 29.3 & 2.4 & 14.5 & 2.0 & 14.9 \\
\hline & Winter wheat & 16.8 & 2.2 & 31.7 & .75 & 9.80 & .09 & 14.9 \\
\hline & Pasture, range & 18.0 & 1.0 & 34.2 & .41 & 14.1 & .34 & 16.5 \\
\hline & Fallow & 16.4 & 2.6 & 19.1 & 1.9 & 4.20 & 1.6 & 4.27 \\
\hline & Alfalfa & 18.0 & 1.0 & 38.9 & .19 & 15.3 & .12 & 21.0 \\
\hline \multirow{6}{*}{$\begin{array}{l}\text { Colby, Canyon, } \\
\text { Ulysses }\end{array}$} & Corn & 16.4 & 2.6 & 33.2 & 1.0 & 15.3 & .96 & 17.7 \\
\hline & Dry beans, grain sorghum & 16.4 & 2.6 & 29.3 & 2.5 & 14.5 & 2.2 & 15.0 \\
\hline & Winter wheat & 16.4 & 2.6 & 31.7 & .66 & 9.85 & .07 & 15.3 \\
\hline & Pasture, range & 16.8 & 2.2 & 34.2 & .32 & 15.0 & .27 & 17.6 \\
\hline & Fallow & 16.4 & 2.6 & 19.1 & 2.0 & 4.25 & 1.7 & 4.38 \\
\hline & Alfalfa & 16.8 & 2.2 & 38.9 & .15 & 15.9 & .10 & 22.2 \\
\hline \multirow{6}{*}{$\begin{array}{l}\text { Jayem, Haxtun, } \\
\text { Rosebud, Keith }\end{array}$} & Corn & 18.0 & 1.0 & 33.2 & 2.2 & 14.5 & 2.1 & 17.3 \\
\hline & Dry beans, grain sorghum & 18.0 & 1.0 & 29.3 & 3.9 & 14.1 & 3.7 & 14.9 \\
\hline & Winter wheat & 18.0 & 1.0 & 31.7 & 1.2 & 8.61 & .38 & 14.0 \\
\hline & Pasture, range & 18.7 & .32 & 34.2 & 1.1 & 13.7 & 1.1 & 16.5 \\
\hline & Fallow & 18.0 & 1.0 & 19.1 & 3.5 & 3.88 & 3.2 & 4.29 \\
\hline & Alfalfa & 18.7 & .32 & 38.9 & .43 & 14.4 & .36 & 20.6 \\
\hline \multirow{6}{*}{$\begin{array}{l}\text { Valent, Valentine, } \\
\text { Tassel }\end{array}$} & Corn & 18.7 & .32 & 33.2 & 3.8 & 14.8 & 3.7 & 18.2 \\
\hline & Dry beans, grain sorghum & 18.7 & .32 & 29.3 & 5.4 & 14.4 & 5.3 & 15.9 \\
\hline & Winter wheat & 18.7 & .32 & 31.7 & 2.1 & 7.40 & 1.7 & 14.6 \\
\hline & Pasture, range & 18.7 & .32 & 34.2 & 2.4 & 13.9 & 2.4 & 17.8 \\
\hline & Fallow & 18.0 & 1.0 & 19.0 & 4.3 & 4.3 & 4.2 & 5.34 \\
\hline & Alfalfa & 18.7 & .32 & 38.9 & 1.2 & 14.0 & 1.2 & 21.4 \\
\hline \multicolumn{9}{|c|}{ Madrid (precipitation, 19.1 inches per year) } \\
\hline \multirow{6}{*}{$\begin{array}{l}\text { Rosebud, } \\
\text { Alliance, } \\
\text { Kuma, Goshen, } \\
\text { Keith }\end{array}$} & Corn & 18.1 & 1.0 & 33.9 & 1.7 & 14.6 & 1.5 & 17.3 \\
\hline & Dry beans, grain sorghum & 18.1 & 1.0 & 29.9 & 3.5 & 14.3 & 3.3 & 15.0 \\
\hline & Winter wheat & 18.1 & 1.0 & 31.8 & .89 & 8.51 & .26 & 13.9 \\
\hline & Pasture, range & 18.8 & .30 & 34.7 & .61 & 13.9 & .49 & 16.4 \\
\hline & Fallow & 17.0 & 2.1 & 19.4 & 2.3 & 4.20 & 2.1 & 4.44 \\
\hline & Alfalfa & 18.8 & .30 & 39.7 & .23 & 15.0 & .15 & 21.0 \\
\hline
\end{tabular}


Table 11. Output from soil-water program, given as annual averages, $1951-89$, using data from the Haigler, Imperial, and Madrid weather stations-Continued

\begin{tabular}{|c|c|c|c|c|c|c|c|c|}
\hline \multirow[b]{2}{*}{ Soil series } & \multirow[b]{2}{*}{ Land use } & \multicolumn{7}{|c|}{ Annual average (inches) } \\
\hline & & 1 & RO & ET & DPI & CIR & DPD & STD \\
\hline \multicolumn{9}{|c|}{ Madrid (precipitation, 19.1 inches per year)—Continued } \\
\hline \multirow{6}{*}{$\begin{array}{l}\text { Jayem, Haxtun, } \\
\text { Rosebud, Keith }\end{array}$} & Corn & 18.1 & 1.0 & 33.9 & 2.2 & 14.9 & 2.1 & 17.9 \\
\hline & Dry beans, grain sorghum & 18.1 & 1.0 & 29.9 & 4.0 & 14.6 & 3.9 & 15.6 \\
\hline & Winter wheat & 18.1 & 1.0 & 31.8 & .95 & 8.03 & .38 & 14.0 \\
\hline & Pasture, range & 18.8 & .30 & 34.7 & 1.1 & 14.0 & 1.0 & 16.9 \\
\hline & Fallow & 18.1 & 1.0 & 19.4 & 3.5 & 4.04 & 3.3 & 4.54 \\
\hline & Alfalfa & 18.8 & .30 & 39.7 & .37 & 14.8 & .30 & 21.2 \\
\hline \multirow{6}{*}{$\begin{array}{l}\text { Jayem, Sarben, } \\
\text { Valent, Hersch, } \\
\text { Valentine }\end{array}$} & Corn & 18.1 & 1.0 & 33.9 & 2.7 & 15.1 & 2.6 & 18.4 \\
\hline & Dry beans, grain sorghum & 18.1 & 1.0 & 29.9 & 4.4 & 14.8 & 4.3 & 16.0 \\
\hline & Winter wheat & 18.1 & 1.0 & 31.8 & 1.0 & 7.66 & .53 & 14.1 \\
\hline & Pasture, range & 18.1 & 1.0 & 34.7 & 1.3 & 14.5 & 1.2 & 17.8 \\
\hline & Fallow & 18.1 & 1.0 & 19.4 & 3.9 & 4.20 & 3.7 & 4.96 \\
\hline & Alfalfa & 18.1 & 1.0 & 39.7 & .53 & 15.0 & .47 & 22.0 \\
\hline \multirow{6}{*}{$\begin{array}{l}\text { Gothenburg, } \\
\text { Platte, Las, } \\
\text { Las Animas }\end{array}$} & Corn & 18.1 & 1.0 & 33.9 & 2.8 & 15.2 & 2.8 & 18.6 \\
\hline & Dry beans, grain sorghum & 18.1 & 1.0 & 29.9 & 4.6 & 14.9 & 4.5 & 16.2 \\
\hline & Winter wheat & 18.8 & .30 & 31.8 & 1.3 & 7.29 & .80 & 13.8 \\
\hline & Pasture, range & 18.8 & .30 & 34.7 & 1.7 & 14.1 & 1.6 & 17.5 \\
\hline & Fallow & 18.1 & 1.0 & 19.4 & 4.0 & 4.25 & 3.9 & 5.10 \\
\hline & Alfalfa & 18.8 & .30 & 39.7 & .70 & 14.6 & .64 & 21.5 \\
\hline \multirow{6}{*}{$\begin{array}{l}\text { Valent, Valentine, } \\
\text { Tassel }\end{array}$} & Corn & 18.8 & .30 & 33.9 & 3.9 & 15.3 & 3.9 & 19.0 \\
\hline & Dry beans, grain sorghum & 18.8 & .30 & 29.9 & 5.6 & 15.0 & 5.5 & 16.6 \\
\hline & Winter wheat & 18.8 & .30 & 31.8 & 1.7 & 6.83 & 1.4 & 14.4 \\
\hline & Pasture, range & 81.8 & .30 & 34.7 & 2.4 & 14.2 & 2.3 & 18.2 \\
\hline & Fallow & 18.1 & 1.0 & 19.4 & 4.5 & 4.45 & 4.4 & 5.69 \\
\hline & Alfalfa & 18.8 & .30 & 39.7 & 1.3 & 14.4 & 1.2 & 22.1 \\
\hline
\end{tabular}

method was a qualitative comparison of simulated and observed water-level surfaces for spring 1989. This comparison is subjective because of the interpretive character of the contoured surfaces. The simulated spring 1989 water table (fig. 23) compares favorably with the observed spring 1989 water table (fig. 7). The differences between these two water tables are illustrated in figure 24 . The differences are within 10 feet for much of the study area, with maximum differences less than 40 feet in a small area in Dundy County near the Republican River.

A second, more objective, method was an error analysis of simulated and observed 1989 water tables. The RMSE was used as an indication of how closely these two water tables match. The RMSE of the computed and observed 1989 water tables is 8.8 feet for the 3,638 active cells within the study area. This error is less than the 10-foot contour interval used in drawing the observed 1952 and 1989 water-table configuration maps.

A third method consisted of comparing measured and simulated streamflows in the study area (table 12). Only the interior streams were evaluated because the boundary streams are regulated by upstream reservoirs and were simulated as constant-head cells. The simulated streamflows are calculated for January 1 through May 31, 1989. Measured streamflows are the mean seasonal values. An examination 


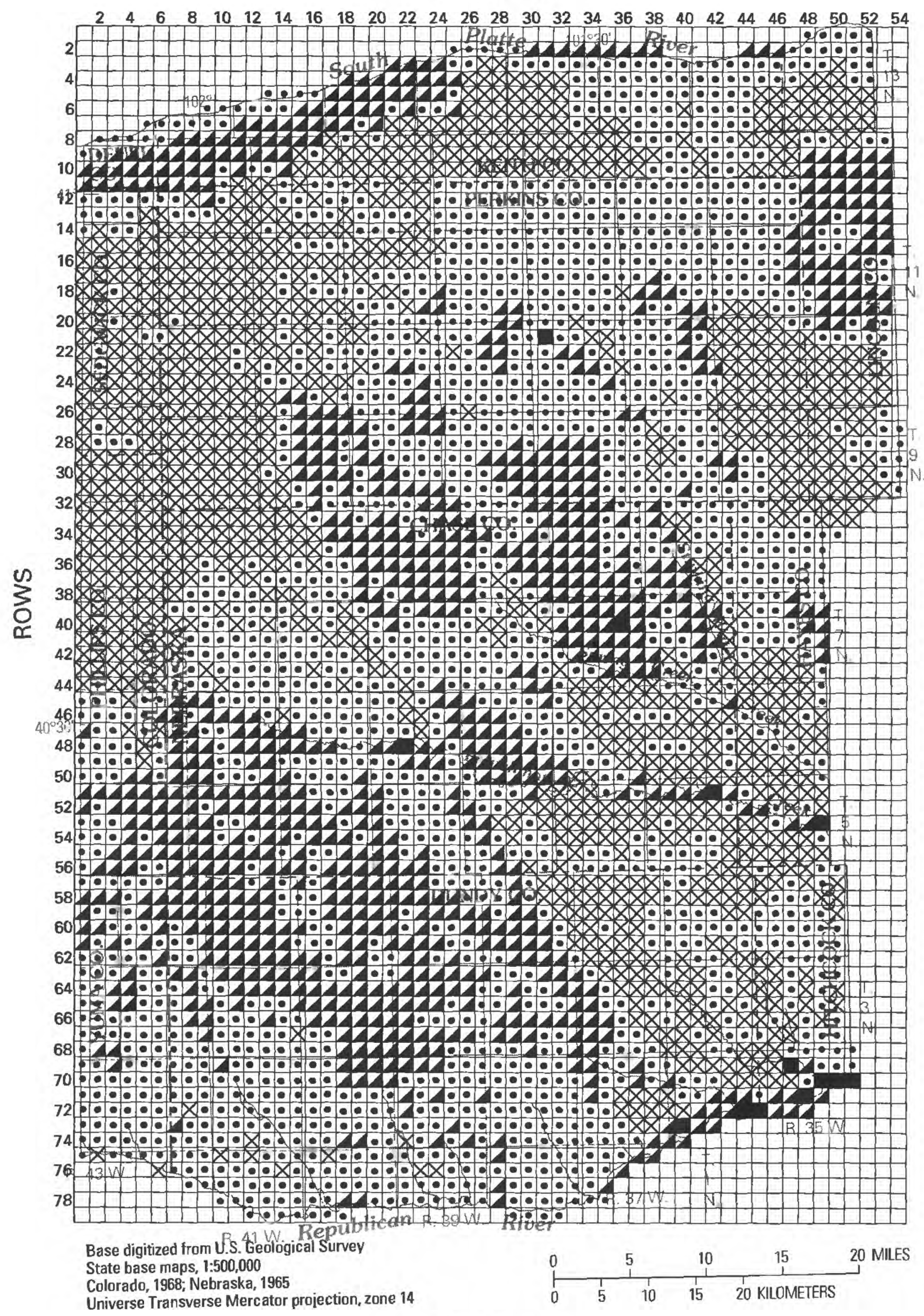

\section{EXPLANATION}

Average recharge 1952-88,

in inches per year

$\square$ Inactive cell $\square 2.01$ to 3.00
$\square 0$ to $1.00 \quad \square$ more than 3.00
$\square 1.01$ to 2.00

Figure 20. Average recharge assigned to model cells for $1952-88$.

40 Simulated Response of the High Plains Aquifer to Ground-Water Withdrawals, Upper Republican Natural Resources District, Nebraska 


\section{COLUMNS}

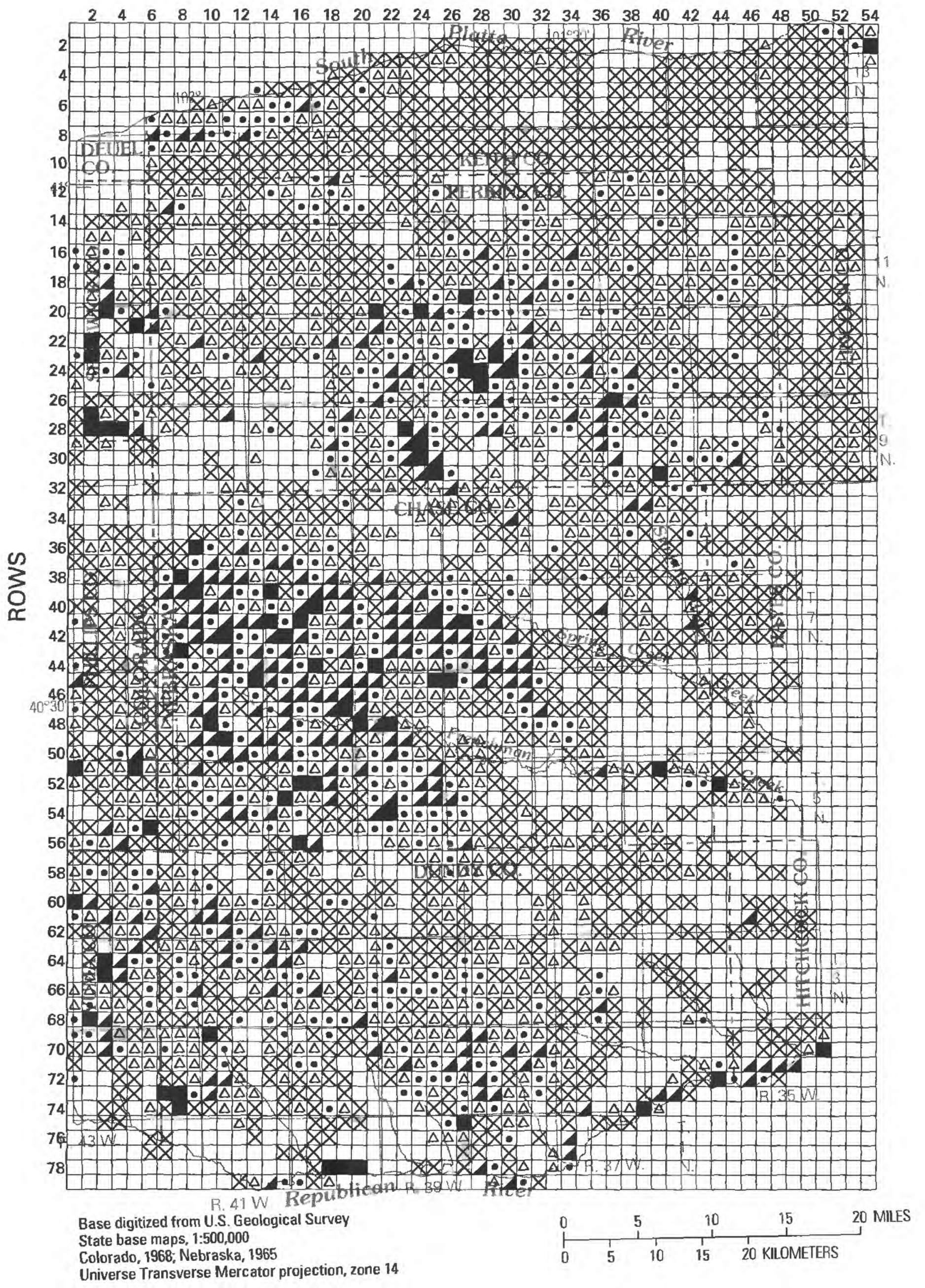

\section{EXPLANATION}

Pumpage for June-August 1988 stress period, in inches

$\square$ No water applied $\quad \bullet 5.01$ to 7.25

$\triangle 0$ to $2.50 \quad \square .26$ to 10.00

$\triangle 2.51$ to $5.00 \quad$ More than 10.00

Figure 21. Pumpage assigned to cells for the June-August 1988 stress period. 


\section{COLUMNS}

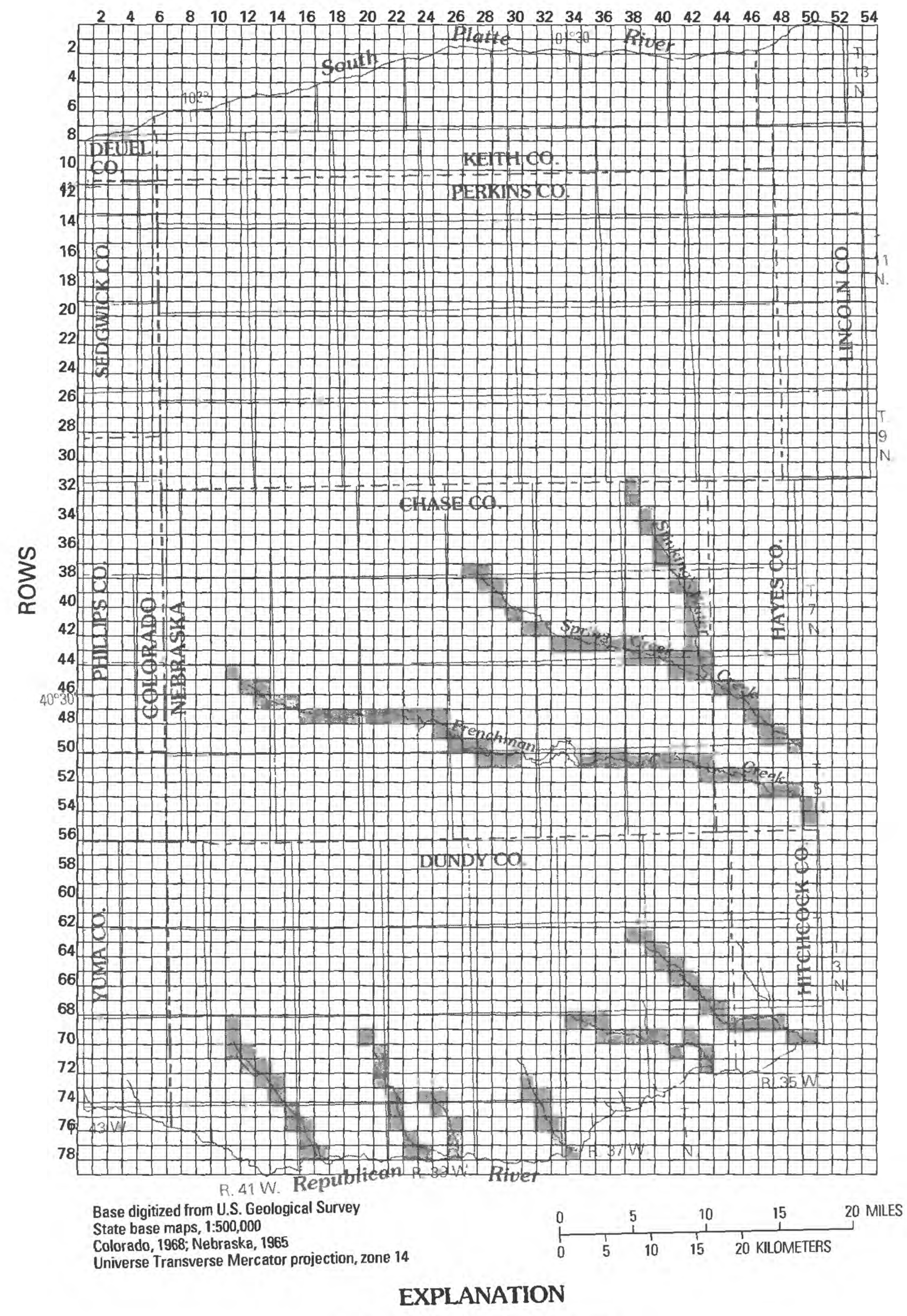

Cell used to simulate an interior stream or river

Figure 22. Cells used to simulate interior streams and rivers using the stream-routing package.

42 Simulated Response of the High Plsins Aquifer to Ground-Water Withdrawsls, Upper Republicsn Natural Resources Dlstrict, Nebrsska 


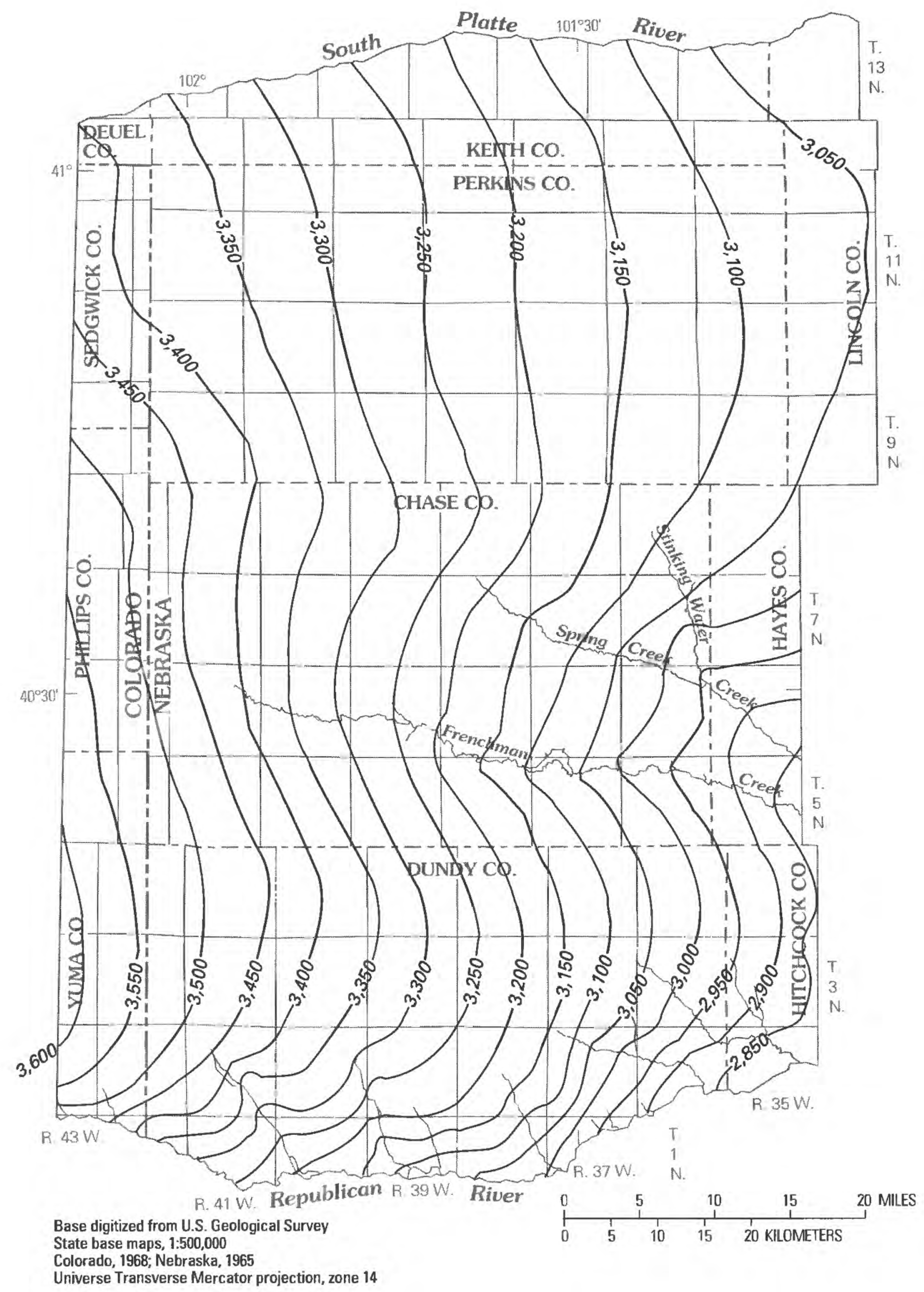

EXPLANATION

$-3,100$ - Simulated water-table contour-Shows altitude of water table, spring 1989. Datum is sea

level. Contour interval 50 feet

Flgure 23. Simulated water-table altitude in the High Plains aquifer, spring 1989. 


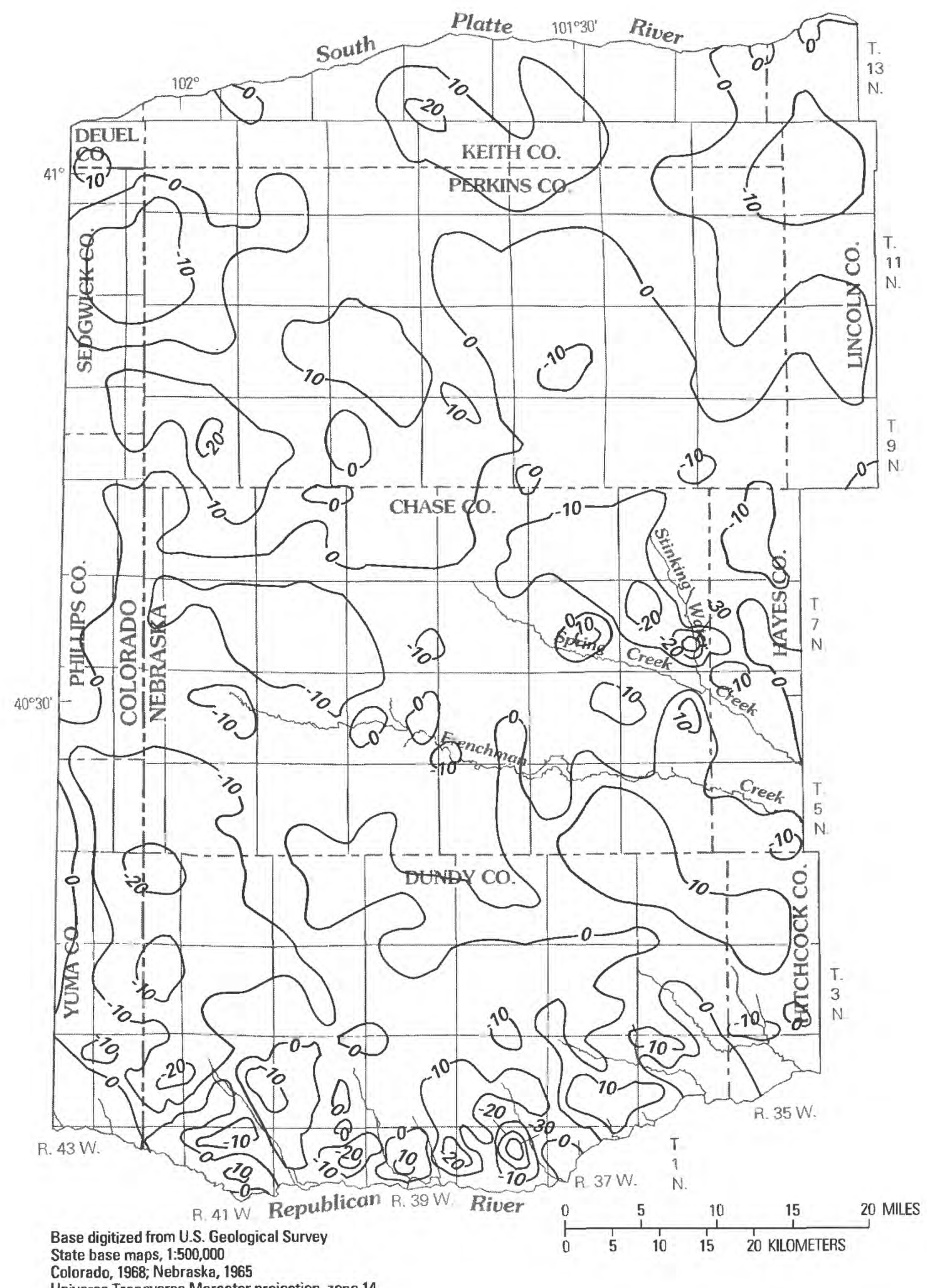

State base maps, 1:500,000

Universe Transverse Mercator projection, zone 14

\section{EXPLANATION}

- 20 - Line of equal difference between simulated and observed water-table altitudes-Positive value indicates that simulated value is greater than observed. Negative $(-)$ value indicates that simulated value is less than observed. Interval 10 feet

Figure 24. Difference between simulated and observed spring 1989 water-table altitudes in the High Plains aquifer. 
Table 12. Comparison of measured and simulated streamflow at selected seepage-measurement sites in the study area

[1952 measured flow from Lappala (1978); 1989 measured flow from U.S. Geological Survey (1990); --, no measurement]

\begin{tabular}{|c|c|c|c|c|}
\hline \multirow{2}{*}{$\begin{array}{l}\text { Seepage-measurement site and } \\
\text { streamflow-gaging statlon number } \\
\text { (fig. 14) }\end{array}$} & \multirow{2}{*}{$\begin{array}{c}\text { Cell } \\
\text { (row, column) } \\
\text { (fig. 15) }\end{array}$} & \multicolumn{3}{|c|}{ Streamflow, in cubic feet per second } \\
\hline & & $\begin{array}{l}\text { Measured } \\
\text { fall } 1952\end{array}$ & $\begin{array}{l}\text { Measured } \\
\text { spring } 1989\end{array}$ & $\begin{array}{l}\text { Simulated } \\
\text { May } 31,1989\end{array}$ \\
\hline $\begin{array}{l}\text { Stinking Water Creek } \\
\text { (above Spring Creek) }\end{array}$ & $(44,43)$ & - & 7.0 & 3.9 \\
\hline Spring Creek & $(45,42)$ & -- & 10.4 & 12.2 \\
\hline $\begin{array}{l}\text { Stinking Water Creek near Wauneta } \\
\text { (includes Spring Creek in Chase County) }\end{array}$ & $(50,49)$ & 21 & 22.9 & 32.2 \\
\hline $\begin{array}{l}\text { Frenchman Creek near Imperial } \\
\quad(6831500)\end{array}$ & $(51,31)$ & 66 & 26.4 & 32.6 \\
\hline $\begin{array}{l}\text { Buffalo Creek near Haigler } \\
\quad(6823500)\end{array}$ & $(78,17)$ & 11 & 6.1 & 11.8 \\
\hline $\begin{array}{l}\text { Rock Creek at Parks } \\
\quad(682400)\end{array}$ & $(78,24)$ & 15 & 11.2 & 11.4 \\
\hline Horse Creek near Parks & $(78,26)$ & $2^{1}$ & .56 & .59 \\
\hline Spring Creek near Benkelman & $(78,34)$ & $1^{1}$ & .18 & .19 \\
\hline Indian Creek near Max & $(72,43)$ & $4^{2}$ & 3.7 & 10.1 \\
\hline Muddy Creek near Republican River & $(70,50)$ & - & 1.7 & 6.6 \\
\hline
\end{tabular}

${ }^{1}$ Average, daily flow, October.

${ }^{2}$ Computed analytically by Lappala (1978, p. 123, using equation on p. 104).

of measured and simulated streamflows shows a reasonable match between these values.

A fourth method of assessing the accuracy of the transient calibration of the model is a comparison through time of simulated versus measured water levels at observation wells. Measured water levels in six observation wells (fig. 25) and simulated water levels in the model cell in which the wells are located were plotted and compared for the period 1952-89. Hydrographs of these six wells are shown in figures 26-28. The simulated and measured water levels for all these sites have similar trends and show reasonable agreement in their water levels for this time period. Because the simulated water levels follow the same trends as the measured water levels in the observation wells, the ground-water-flow model appears to be accurately simulating the response of the High Plains aquifer to stress through time.

\section{Water Budget}

Analysis of model-simulated ground-water flow revealed the magnitude of flow into and out of the High Plains aquifer in the study area. During the cali-bration period of June 1, 1952, through May 31, 1989 , the net decrease in ground-water storage was $6.25 \times 10^{6}$ acre-feet (table 13). The recharge to the ground-water system from deep percolation of precipitation was $1.03 \times 10^{7}$ acre-feet. The stream leakage of ground water into streams was $7.16 \times 10^{6}$ acre-feet. The net volume of ground water moving into or out of the constant-head cells was $1.48 \times 10^{6}$ acre-feet from the aquifer to the constant-head cells. Also, the net volume of ground water moving into or out of the general-head boundaries was $3.87 \times 10^{5}$ acre-feet from the aquifer into the general-head boundaries. Finally, pumpage from the aquifer removed $7.51 \times 10^{6}$ acre-feet of water from storage during the calibration period. 


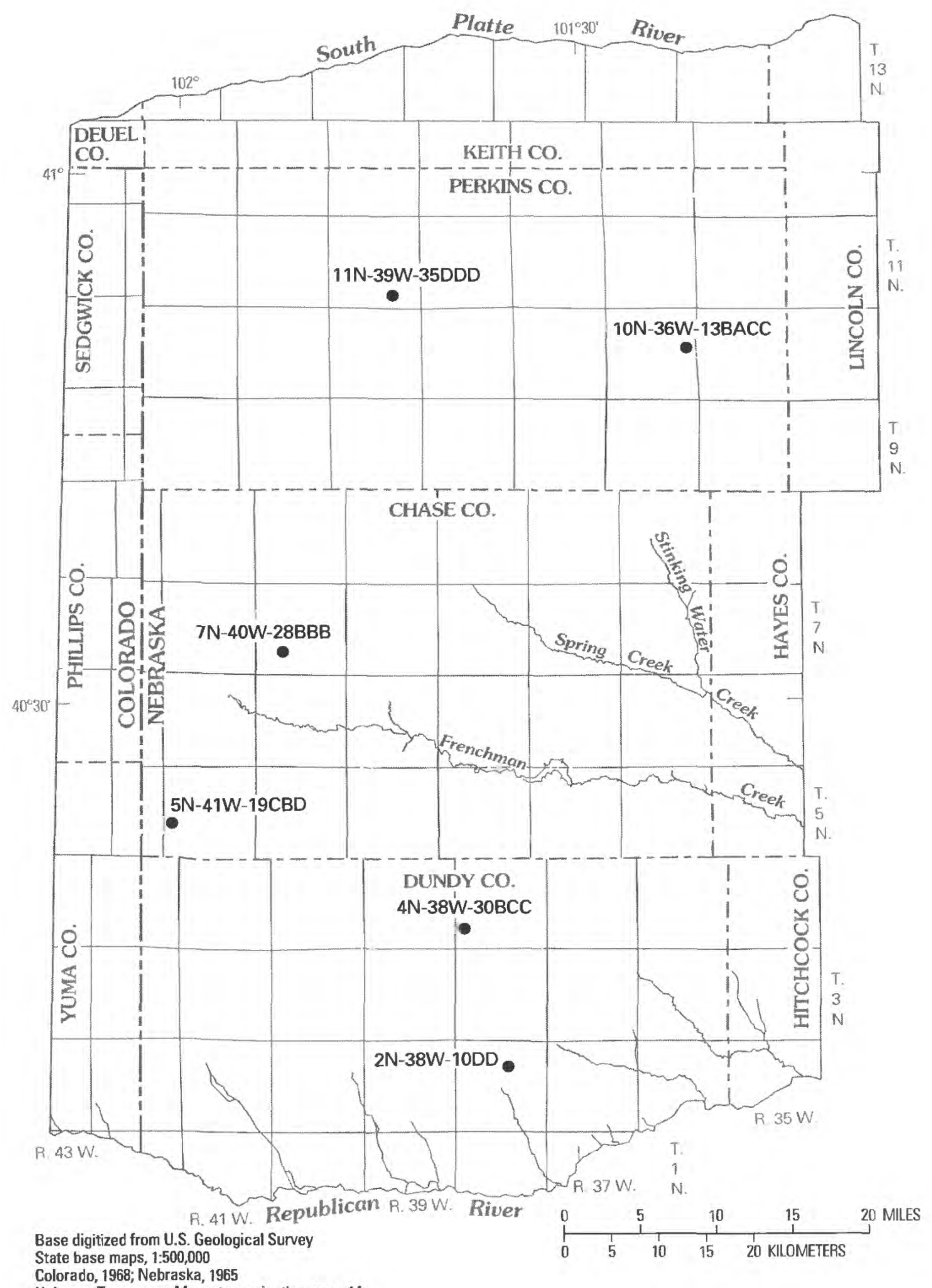

State base maps, 1:500,000

Universe Transverse Mercator projection, zone 14

\section{EXPLANATION}

2N-38W-10DD Observation well with hydrograph shown-Number is well number

shown on hydrographs in figures $26-28$

Figure 25. Location of observation wells with long-term hydrographs shown in figures $26-28$. 


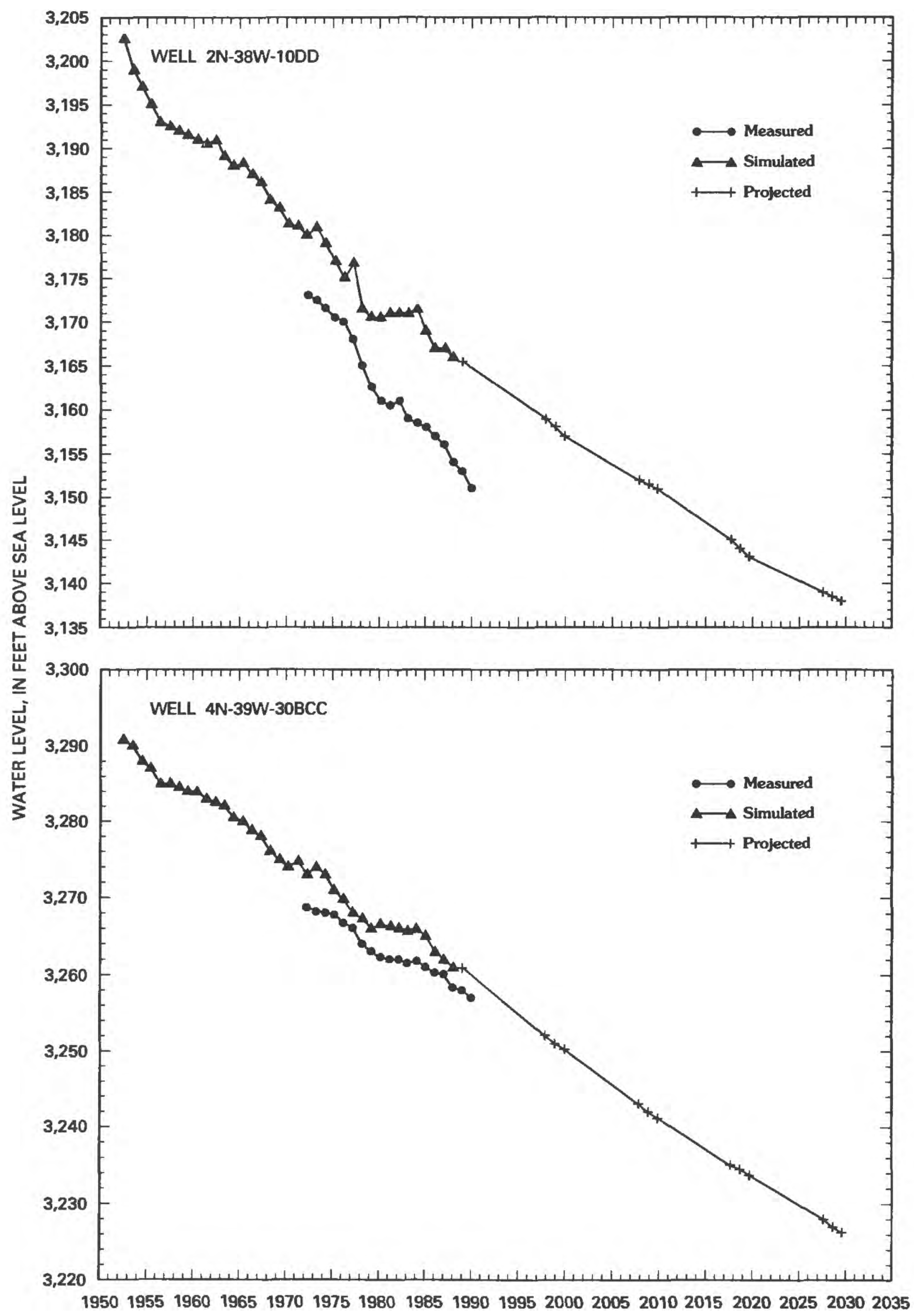

Figure 26. Hydrographs showing measured, simulated, and projected water levels for observation wells $2 \mathrm{~N}-38 \mathrm{~W}-10 \mathrm{DD}$ and $4 \mathrm{~N}-38 \mathrm{~W}-30 \mathrm{BCC}$. 


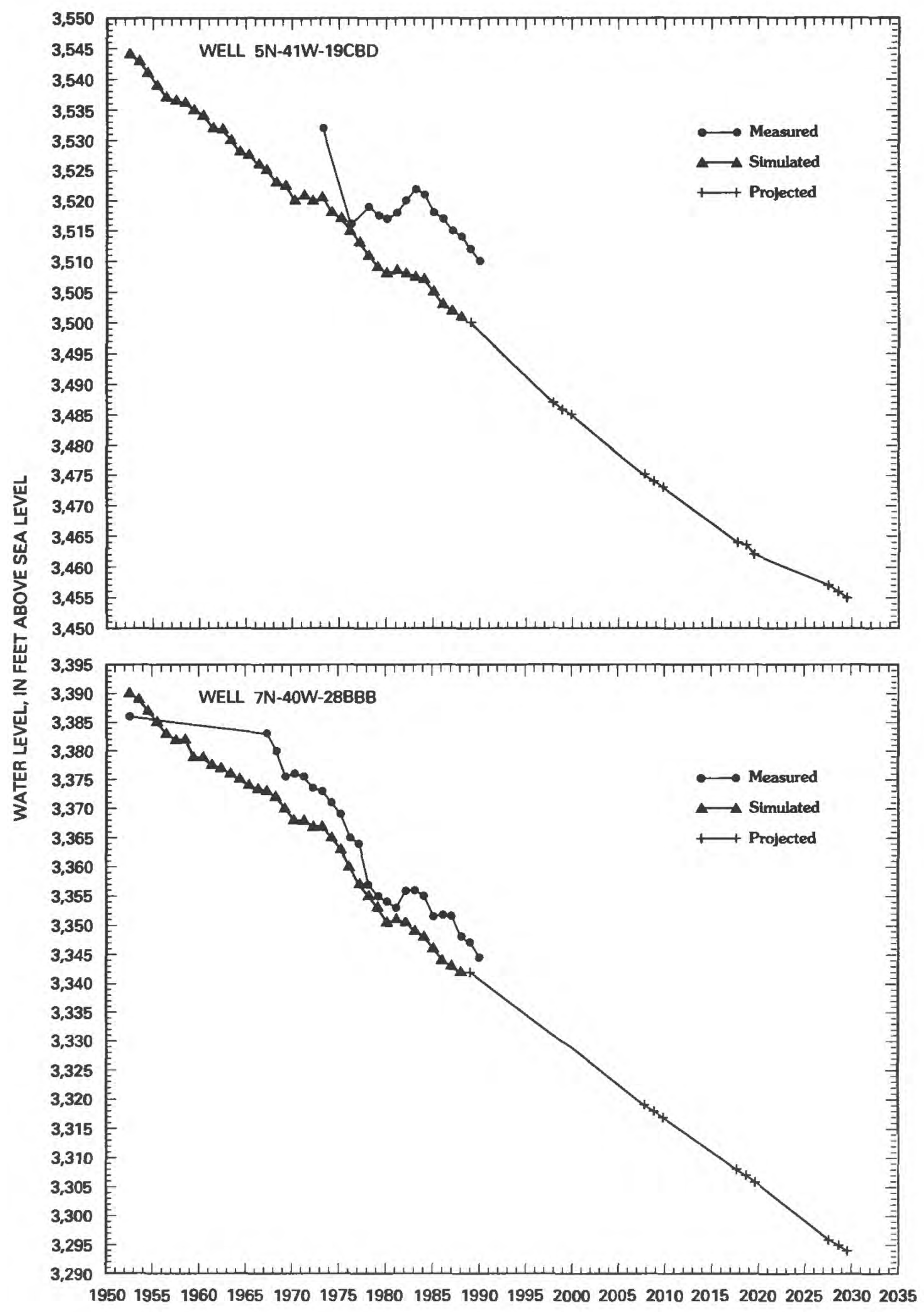

Figure 27. Hydrographs showing measured, simulated, and projected water levels for observation wells $5 \mathrm{~N}-41 \mathrm{~W}-19 \mathrm{CBD}$ and $7 \mathrm{~N}-40 \mathrm{~W}-28 \mathrm{BBB}$.

48 Simuiated Response of the High Piains Aquifer to Ground-Water Withdrawais, Upper Repubiican Natural Resources District, Nebraska 


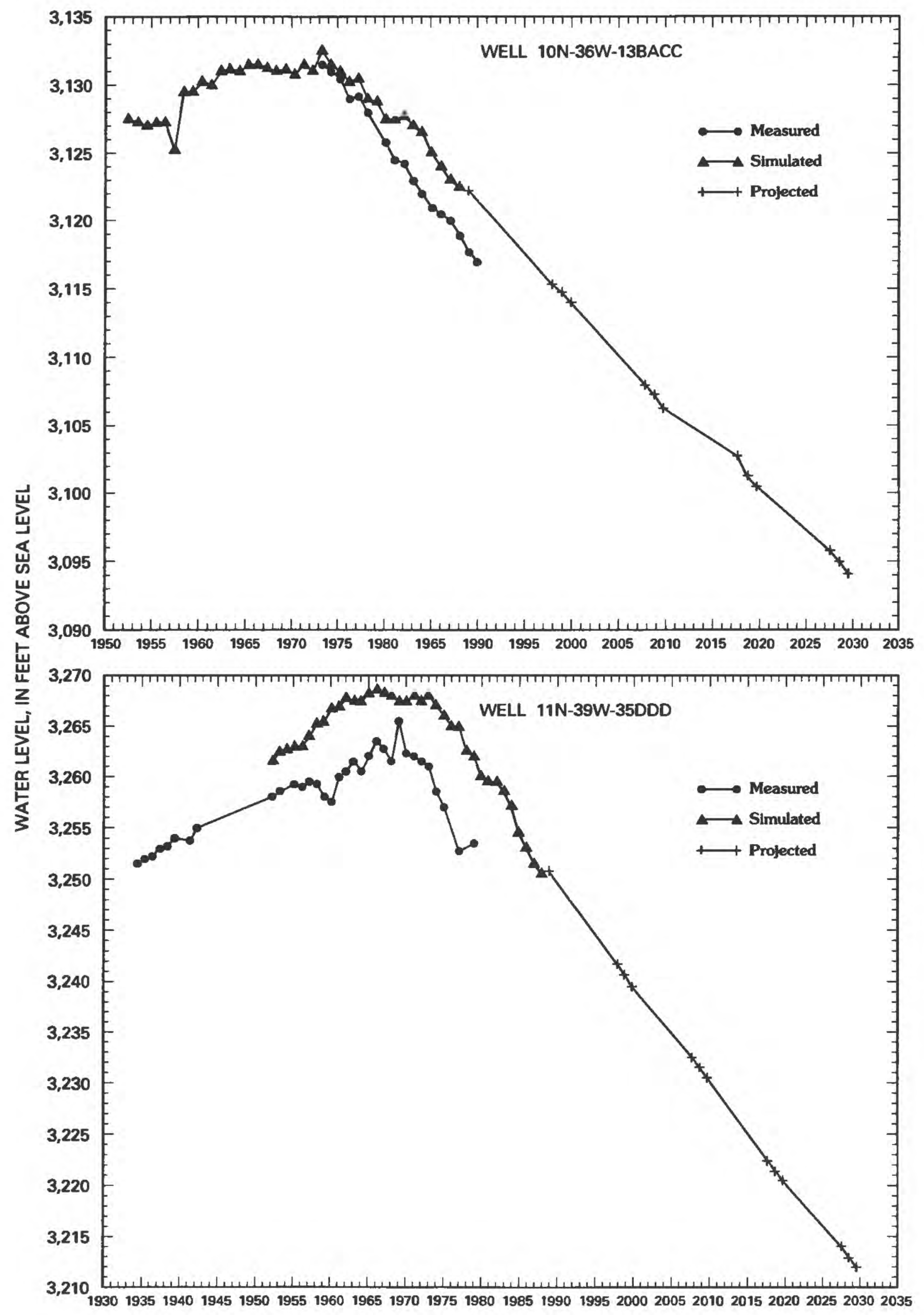

Figure 28. Hydrographs showing measured, simulated, and projected water levels for observation wells $10 \mathrm{~N}-36 \mathrm{~W}-13 \mathrm{BACC}$ and $11 \mathrm{~N}-39 \mathrm{~W}-35 \mathrm{DDD}$. 
Table 13. Simulated water budget for summer 1952 to spring 1989, and 1988

\begin{tabular}{|c|c|c|c|}
\hline Source or sink & $\begin{array}{l}\text { Volume of water } \\
\text { moved into aquifer } \\
\text { (thousands of } \\
\text { acre-feet) }\end{array}$ & & $\begin{array}{l}\text { Volume of water moved } \\
\text { out of aquifer } \\
\text { (thousands of } \\
\text { acre-feet) }\end{array}$ \\
\hline \multicolumn{4}{|c|}{ For summer 1952 to spring 1989} \\
\hline Constant head & 712 & & 2,192 \\
\hline Wells & 0 & & 7,514 \\
\hline Recharge & 10,288 & & 0 \\
\hline General head & 1,666 & & 2,052 \\
\hline Interior streams & 457 & & 7,613 \\
\hline Total & 13,123 & & 19,371 \\
\hline Change in storage $=$ & & $-6,248$ & \\
\hline \multicolumn{4}{|c|}{ For 1988} \\
\hline Constant head & 20 & & 59 \\
\hline Wells & 0 & & 483 \\
\hline Recharge & 386 & & 0 \\
\hline General head & 52 & & 54 \\
\hline Interior streams & 15 & & 136 \\
\hline Total & 473 & & 732 \\
\hline Change in storage $=$ & & -259 & \\
\hline
\end{tabular}

\section{Sensitivity Analysis}

The sensitivity of the model to changes in hydraulic conductivity, specific yield, recharge, and pumpage was evaluated by numerous steady-state and transient simulations in which only one of these model parameters was varied at a time, and the model results were compared with calibration model results. On the basis of these simulations, the model was determined to be most sensitive to variations in recharge and pumpage and more sensitive to variations in specific yield than to variations in hydraulic conductivity.

\section{SIMULATED RESPONSE TO GROUND- WATER WITHDRAWALS}

For this study, the calibrated model was used to estimate possible effects of future ground-water withdrawals on water levels in the High Plains aquifer and on streamflows in the study area. The long-term effects of two different pumping scenarios, the consumptive-irrigation-requirement scenario and the 13-inch scenario, were estimated by comparing simulated water levels in the aquifer during the years
2010 and 2030 for each of the scenarios to water levels in the aquifer in 1989.

All model parameters were the same for each scenario except for the pumpage and recharge values used. It was assumed for both scenarios that no additional well development occurs during the period of the simulation (June 1989 through May 2030).

\section{Consumptive-Irrigation-Requirement Scenario}

The first pumping scenario examined long-term effects on ground-water levels and streamflows if pumpage for 1989-2030 for each model cell was equal to the average CIR used during the model-calibration period (1952-89) and recharge was equal to the recharge for the same period. Simulated changes in water levels from 1989 to 2010 and 2030 , resulting from long-term pumping at this rate, are shown in figures 29 and 30 , respectively. The maximum simulated declines for both time periods occurred in northwestern Chase County. The hydrographs shown in figures 26, 27, and 28 illustrate the steady water-level declines simulated as a result of this scenario. The simulated saturated thickness of the High Plains 


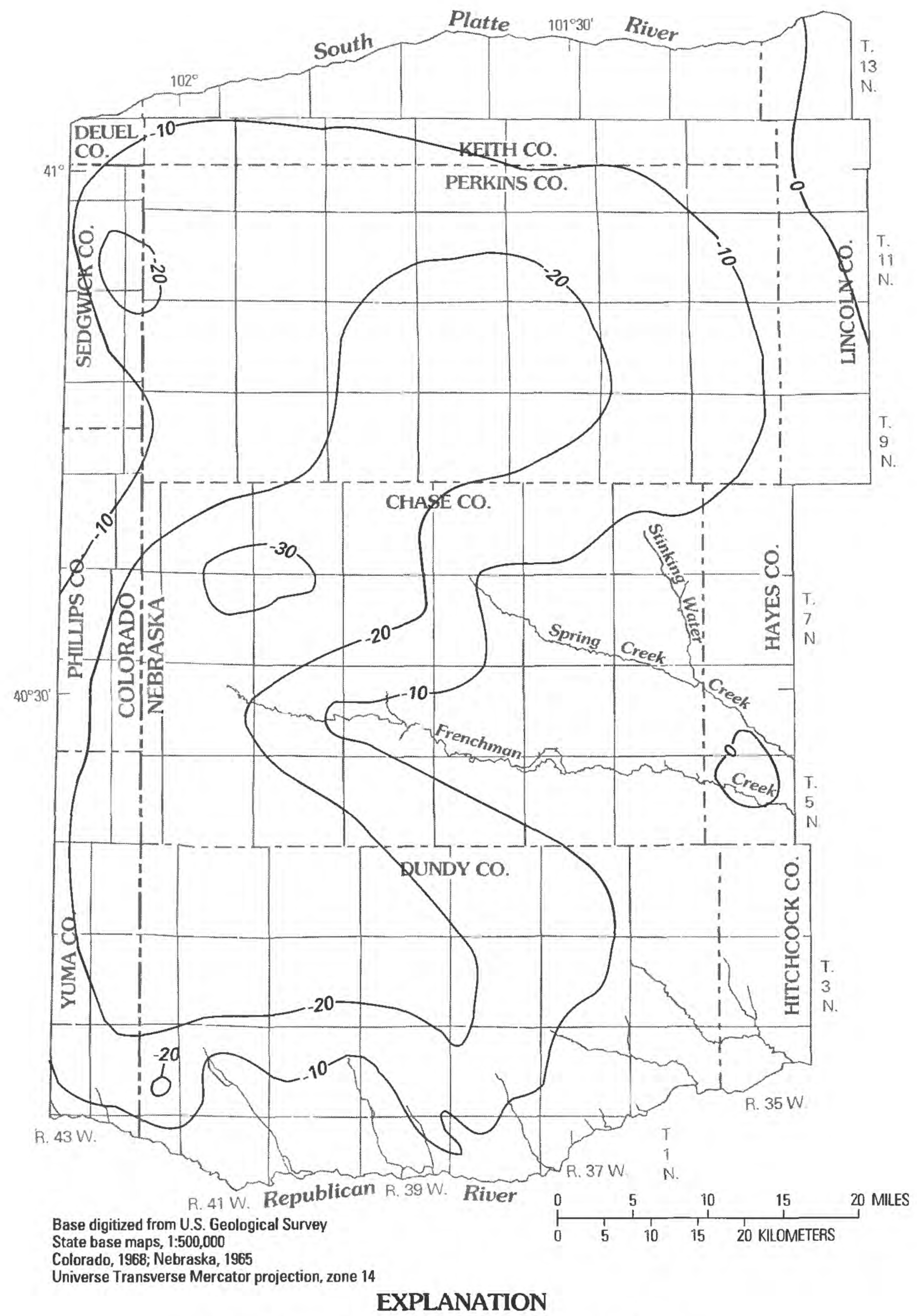

- -20 - Line of equal projected water-level change-

Negative $(-)$ value indicates water-level decline.

Interval 10 feet

Figure 29. Projected water-level changes in the High Plains aquifer, 1989-2010, using consumptive-irrigation-requirement pumping scenario. 


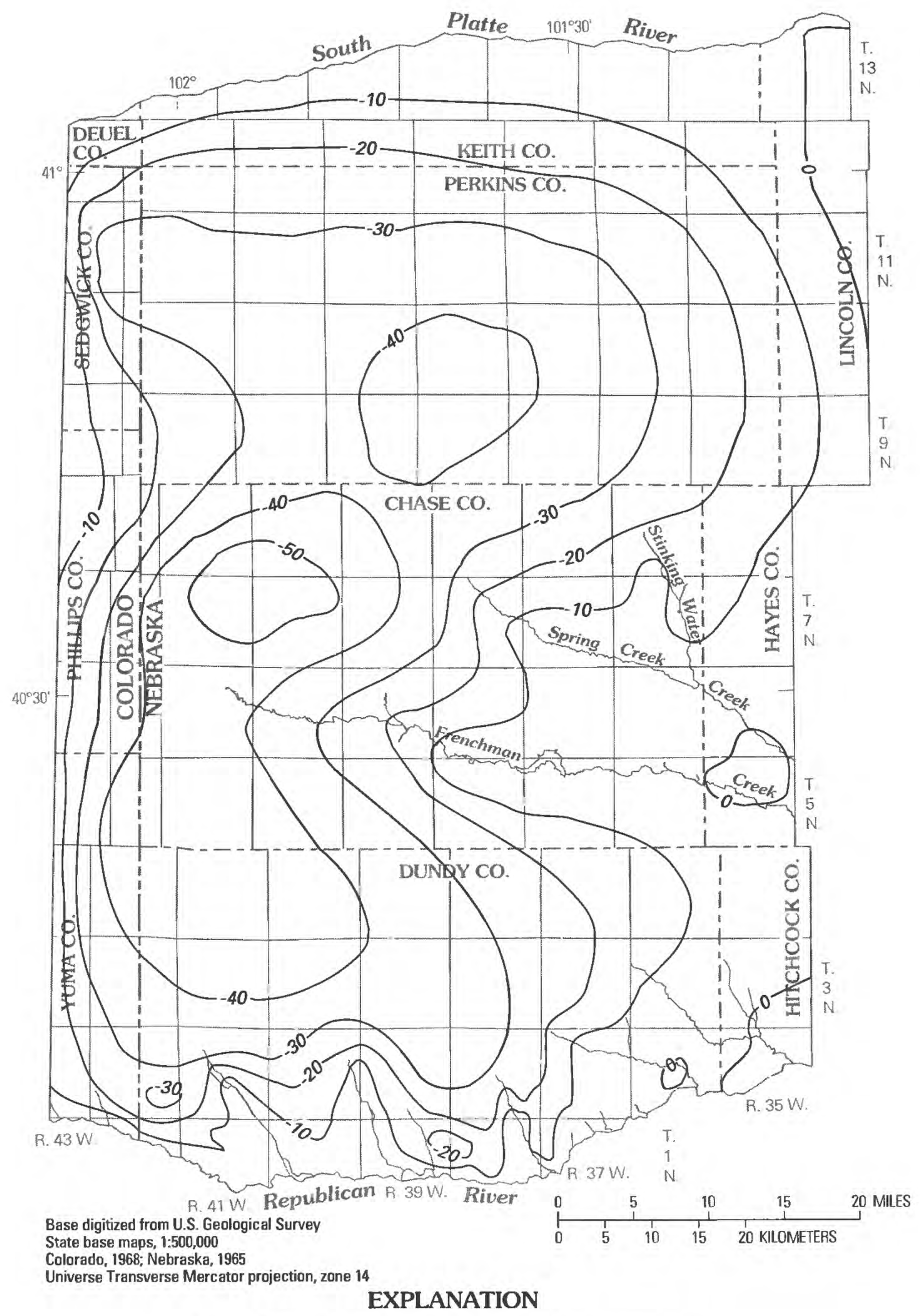

-20 - Line of equal projected water-level change-

Negative $(-)$ value indicates water-level decline.

Interval 10 feet

Figure 30. Projected water-level changes in the High Plains aquifer, 1989-2030, using consumptive-irrigation-requirement pumping scenario. 
aquifer in 2030 resulting from this scenario is shown in figure 31 . The simulated effects of this pumping scenario on streamflow at selected sites are listed in table 14. For example, the simulated stream-flow in Frenchman Creek near Imperial at the end of May 1989 was 32.6 cubic feet per second (table 14), whereas the simulated streamflow at the same location on May 31, 2030, was only 10.2 cubic feet per second (table 14).

\section{"13-Inch" Scenario}

The second pumping scenario examined longterm effects on water levels using a single, constant withdrawal rate instead of the variable CIR-based withdrawal rate in the first scenario. The second scenario predicted the effects of the pumpage and application of 13 inches of water to irrigated fields during the irrigation season (June-August) of each year. Several other similar scenarios were simulated with different application rates. The results of these other similar scenarios are not presented here for brevity. The recharge to nonirrigated lands in nonirrigation periods was not considered in any of these constant withdrawal rate scenarios because it greatly simplified the model preparation to run these scenarios and did not significantly influence the simulation results for these scenarios. Under the 13-inch scenario, maximum water-level declines by the years 2010 (fig. 32) and 2030 (fig. 33) were about 40 and 90 feet, respectively, in northwestern Chase County. The simulated saturated thickness of the High Plains aquifer in 2030 resulting from this scenario is shown in figure 34. The flow in Frenchman Creek near Imperial on May 31, 2030, was predicted to be only 1.6 cubic feet per second (table 14).

\section{LIMITATIONS OF THE MODEL}

This ground-water-flow model was developed to evaluate regional management scenarios. Because of the scale of the model, estimates of water-level and streamflow changes are regional in scope. Therefore, the model should not be used to simulate aquifer responses at individual wells.

The model was designed to handle groundwater-flow simulation problems. It is not an optimization model. The model may be used to simulate the response of the ground-water system to specific pumping scenarios, but it is unable to estimate directly the pumping scenario required to cause a specific response within the system.

This model was specifically designed to simulate the ground-water flow in the Upper Republican NRD. In areas outside the Upper Republican NRD to the east and west, boundary conditions might affect the accuracy of the simulation results.

\section{SUMMARY}

Concern over declining water levels in the High Plains aquifer in the Upper Republican NRD and the decreasing accuracy of an existing ground-water-flow model of the Upper Republican NRD prompted the USGS, as part of continuing cooperative studies with the NRD and the Nebraska Natural Resources Commission, to update this model. The updated model used more recent data and modeling techniques to more accurately simulate ground-water flow in the study area.

The principal aquifer in the study area is the High Plains aquifer. It is confined below by the relatively impermeable White River Group or Pierre Shale. The hydraulic conductivity of the aquifer used in the model ranged from 20 to 155 feet per day, and the specific yield used in the model ranged from 0.09 to 0.22 .

A digital model was developed for the study area using the modular, three-dimensional, finitedifference, ground-water-flow model MODFLOW. The aquifer was represented as a single-layer, regularly spaced grid of 79 rows and 54 columns. Each row and column of the model represented a 1-milewide strip of aquifer.

Boundaries for the model were the South Platte, Republican, and North Fork of the Republican Rivers along the northern and southern edges of the model. These boundaries were designated by constant-head cells. General-head boundaries were used along the western and eastern edges of the study area in the absence of natural boundaries. The bottom of the aquifer was modeled as a no-flow boundary because of the generally impervious nature of the underlying rocks.

Recharge and pumpage were estimated based on soil, climate, and land-use characteristics using two previously documented computer programs, the potential evapotranspiration (PET) program and the soilwater program. Pumpage stresses were included in the model using the well package in MODFLOW, and 


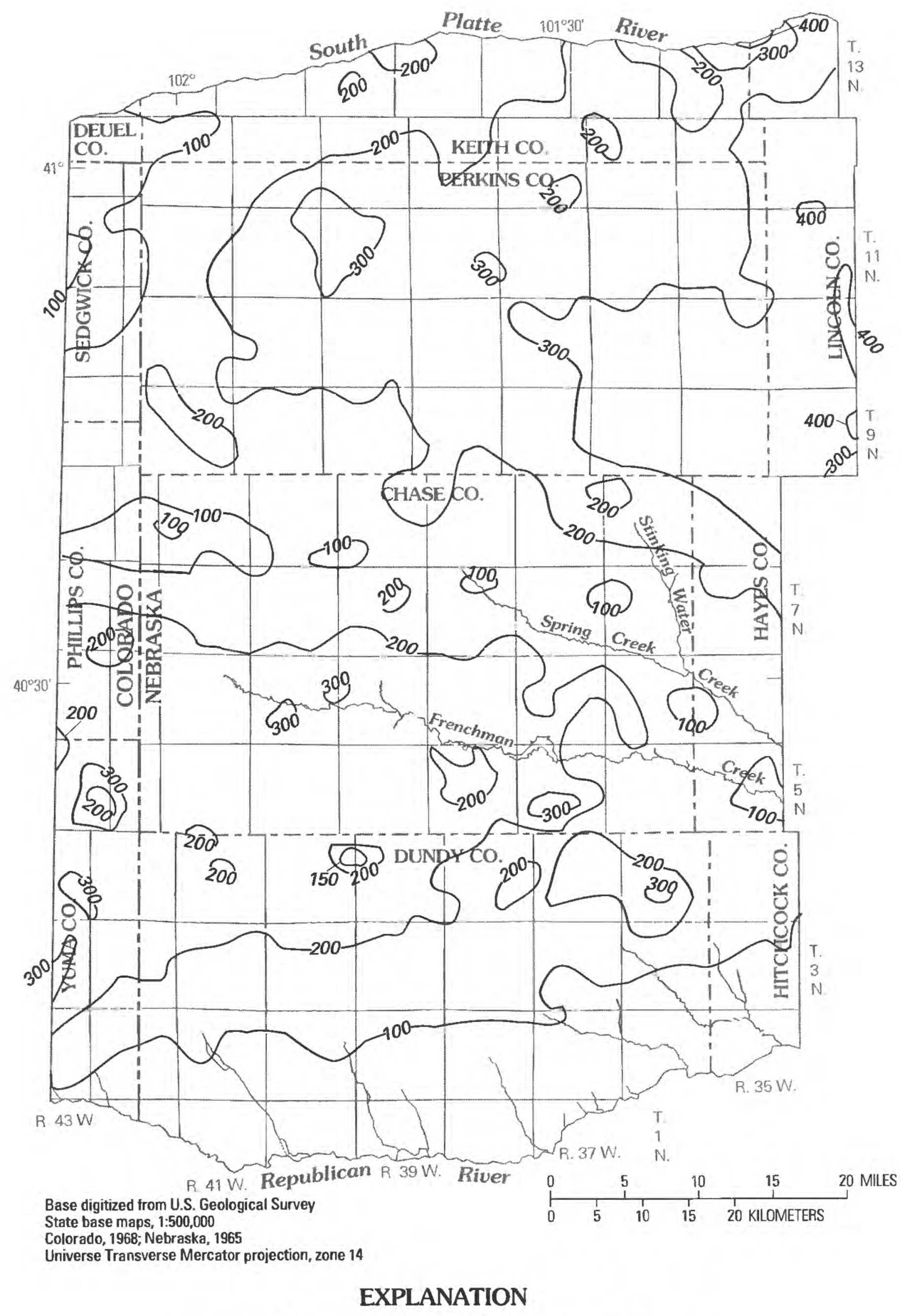

- 300- Line of equal projected saturated thicknessInterval 100 feet

Figure 31. Projected saturated thickness of the High Plains aquifer in 2030 using consumptive-irrigation-requirement pumping scenario. 
Table 14. Comparison of streamflows simulated for 1989 and projected for 2010 and 2030 using the consumptive-irrigation-requirement and 13-inch scenarios at selected seepage-measurement sites in the study area

[values are given in cubic feet per second; CIR, consumptive irrigation requirement]

\begin{tabular}{|c|c|c|c|c|c|c|}
\hline \multirow{3}{*}{$\begin{array}{l}\text { Seepage- } \\
\text { measurement site } \\
\text { and streamflow- } \\
\text { gaging station } \\
\text { number } \\
\text { (fig. 14) }\end{array}$} & \multirow{3}{*}{$\begin{array}{c}\text { Cell } \\
\text { (row, } \\
\text { column) } \\
\text { (flg. 15) }\end{array}$} & \multirow{3}{*}{$\begin{array}{c}\text { SImulated } \\
\text { flow, May } \\
31,1989 \\
\text { (table 12) }\end{array}$} & \multicolumn{4}{|c|}{ Projected flows } \\
\hline & & & \multicolumn{2}{|c|}{ CIR scenario } & \multicolumn{2}{|c|}{ 13-inch scenario } \\
\hline & & & $\begin{array}{l}\text { May 31, } \\
2010\end{array}$ & $\begin{array}{l}\text { May 31, } \\
2030\end{array}$ & May 31, 2010 & May 31, 2030 \\
\hline $\begin{array}{l}\text { Stinking Water Creek } \\
\text { (above Spring Creek) }\end{array}$ & $(44,43)$ & 3.9 & 2.4 & 1.7 & 2.7 & 1.9 \\
\hline Spring Creek & $(45,42)$ & 12.2 & 6.4 & 4.0 & 4.8 & 3.0 \\
\hline $\begin{array}{l}\text { Stinking Water Creek } \\
\text { near Wauneta } \\
\text { (includes Spring } \\
\text { Creek in Chase } \\
\text { County) }\end{array}$ & $(50,49)$ & 32.2 & 15.0 & 14.8 & 15.2 & 14.9 \\
\hline $\begin{array}{l}\text { Frenchman Creek near } \\
\text { Imperial }(6831500)\end{array}$ & $(51,31)$ & 32.6 & 15.7 & 10.2 & 8.6 & 1.6 \\
\hline $\begin{array}{l}\text { Buffalo Creek near } \\
\text { Haigler }(6823500)\end{array}$ & $(78,17)$ & 11.8 & 7.3 & 5.5 & 7.5 & 5.1 \\
\hline $\begin{array}{l}\text { Rock Creek at Parks } \\
(682400)\end{array}$ & $(78,24)$ & 11.4 & 8.0 & 5.4 & 6.5 & 4.2 \\
\hline Horse Creek near Parks & $(78,26)$ & .59 & .12 & 0 & 0 & 0 \\
\hline $\begin{array}{l}\text { Spring Creek near } \\
\text { Benkelman }\end{array}$ & $(78,34)$ & .19 & 0 & 0 & 0 & 0 \\
\hline Indian Creek near Max & $(72,43)$ & 10.1 & 8.3 & 6.8 & 7.3 & 5.1 \\
\hline $\begin{array}{l}\text { Muddy Creek near } \\
\text { Republican River }\end{array}$ & $(70,50)$ & 6.6 & 6.6 & 5.4 & 6.6 & 5.0 \\
\hline
\end{tabular}

recharge was applied using the recharge package in MODFLOW. Stream-aquifer interaction was simulated using a stream-routing package for MODFLOW.

The model was calibrated under steady-state conditions by adjusting input data including hydraulic conductivity, streamflows assigned to the upstream reach of each stream segment, and boundary head and conductance in general-head boundary cells. Calibration under transient conditions also included adjustment of specific yield, recharge, and pumpage values. A root mean square error of 8.8 feet was obtained for the transient calibration, indicating that the model was adequately simulating transient conditions. Sensitivity analysis indicated that the model was most sensitive to recharge and pumpage and least sensitive to hydraulic conductivity. Analysis of model results indicated that over the period from June 1, 1952, to May 31, 1989, the volume of water removed from storage was $6.2510^{6}$ acre-feet.

Possible long-term effects of two pumping scenarios were evaluated for 1989-2030. For the first scenario, pumpage was held constant at the rate necessary to supply a crop's consumptive irrigation requirement. Simulated water-level declines resulting from this scenario were greatest in northwestern Chase County. A second scenario held pumpage constant at the rate necessary to apply 13 inches of water to irrigated crops during the irrigation season. Simulated 


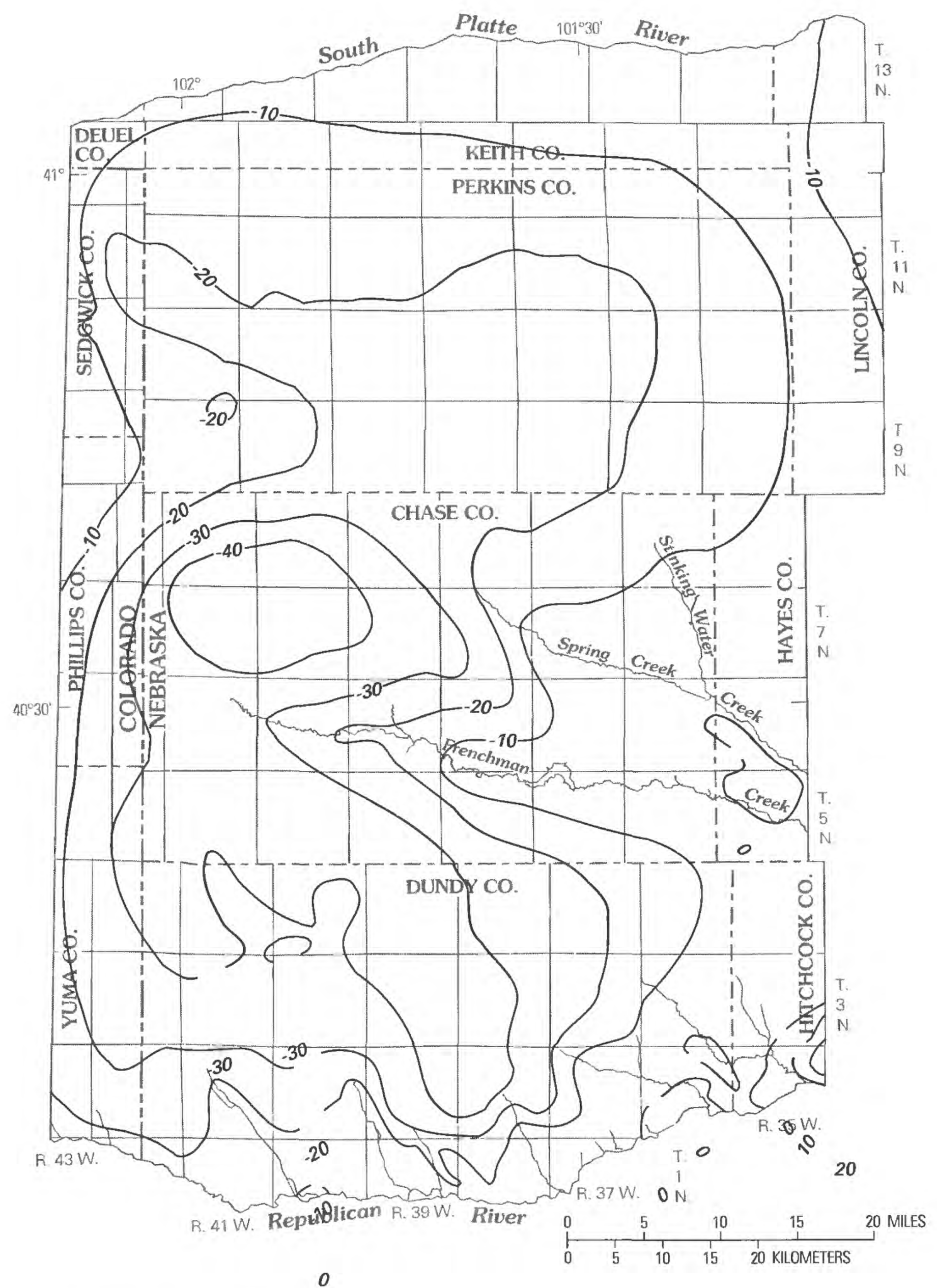

Base digitized from U.S. Geological Survey

State base maps, 1:500,000

Colorado, 1968; Nebraska, 1965

Universe Transverse Mercaturprojection, zone 14

\section{EXPLANATION}

-20 Line of equal projected water-level change-

Negative $(-)$ value indicates water-level decline.

Positive value indicates water-level rise.

Interval 10 feet

Figure 32. Projected water-level changes in the High Plains aquifer, 1989-2010, using 13-inch pumping scenario.

56 Simulated Response of the High Piains Aquifer to Ground-Water Withdrawals, Upper Republican Naturai Resources District, Nebraska 


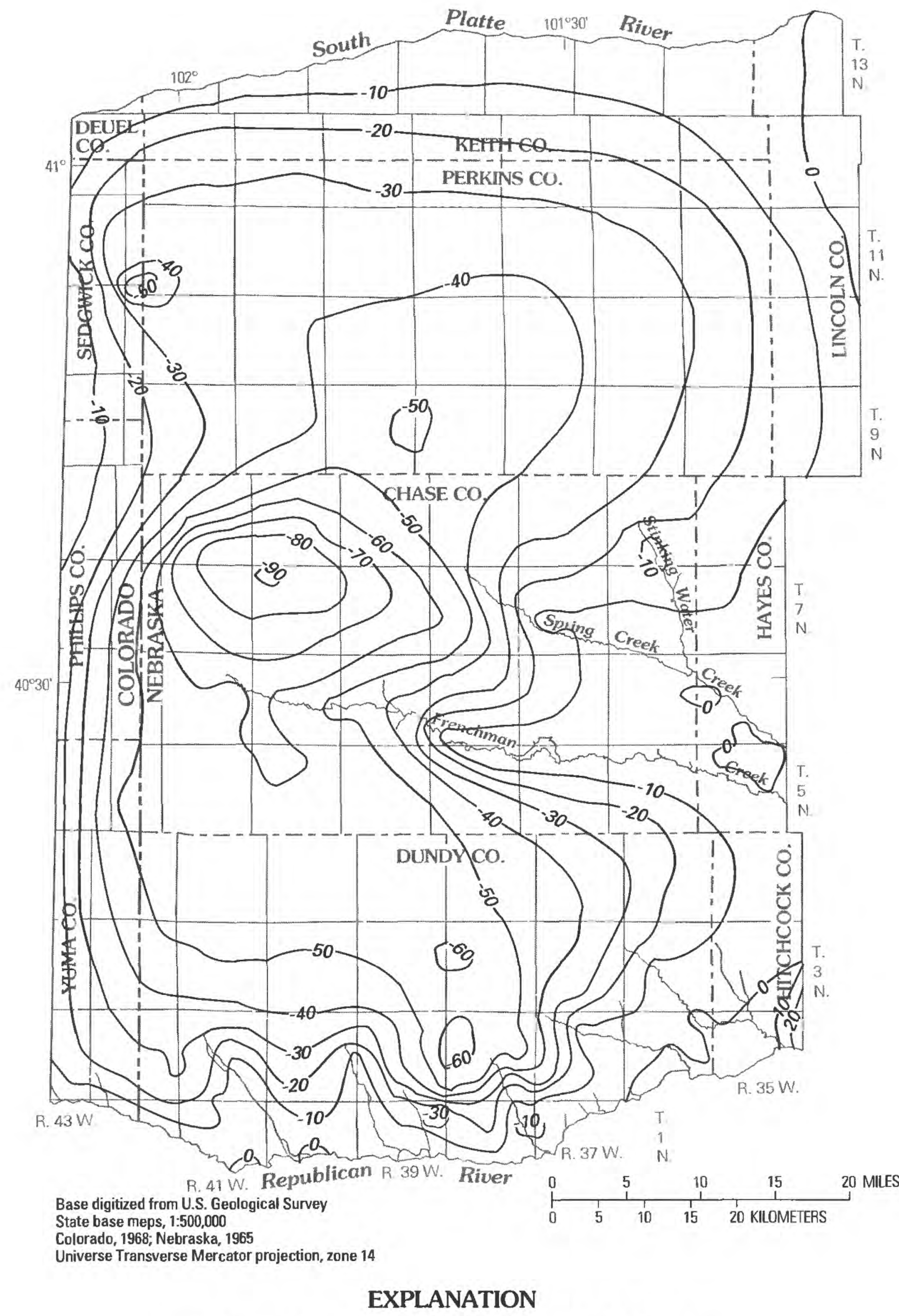

-20 - Line of equal projected water-level change-

Negative $(-)$ value indicates water-level decline.

Positive value indicates water-level rise.

Interval is 10 feet

Figure 33. Projected water-level changes in the High Plains aquifer, 1989-2030, using 13-inch pumping scenario. 


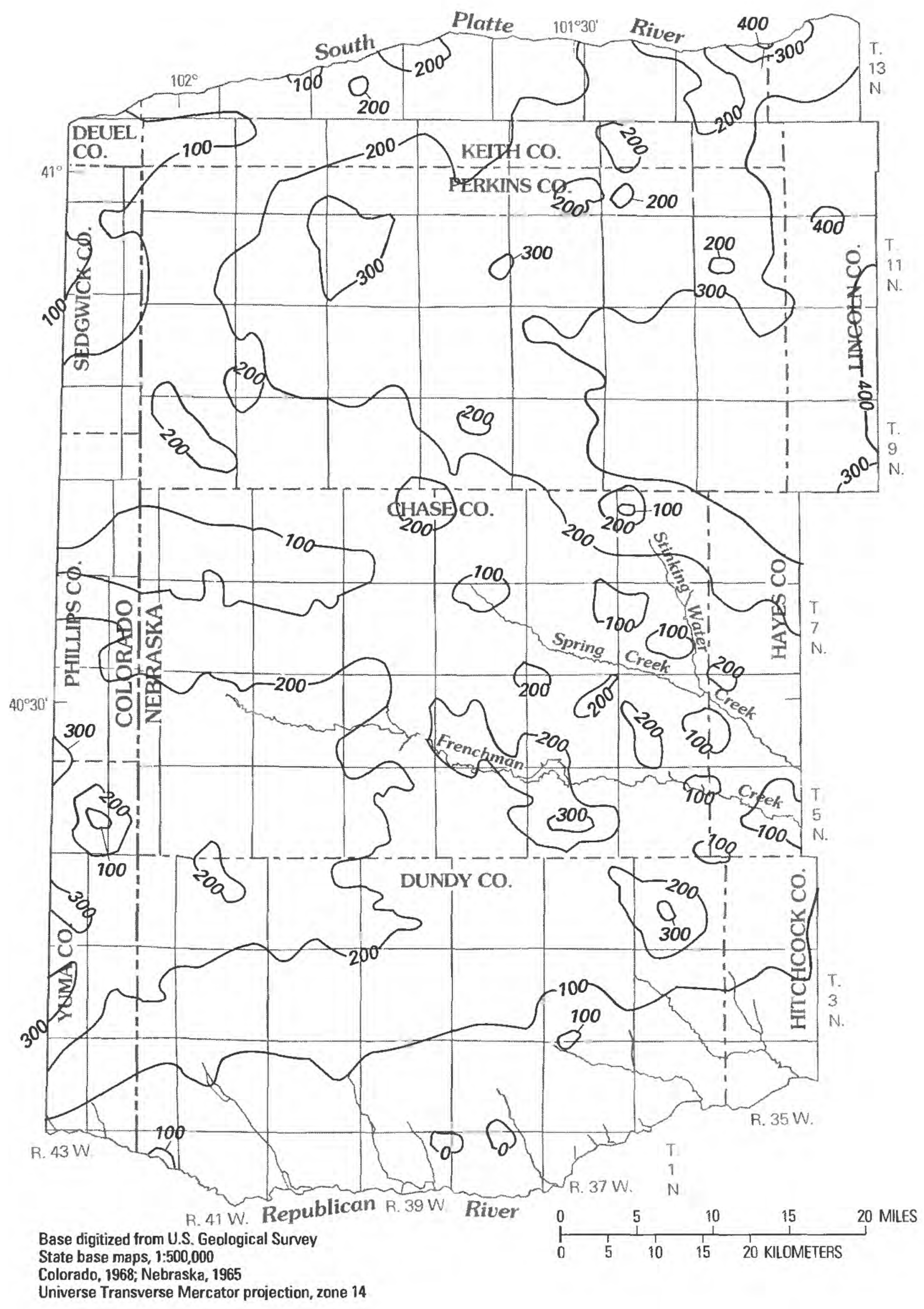

\section{EXPLANATION}

- 300 - Line of equal projected saturated

thickness-Interval 100 feet

Figure 34. Projected saturated thickness of the High Plains aquifer in 2030 using 13 -inch pumping scenario. 
water-level declines resulting from this scenario were even larger than those for the first pumping scenario. Water levels would decline as much as 90 feet by 2030 in northwestern Chase County.

\section{SELECTED REFERENCES}

Bjorklund, L.J., and Brown, R.F., 1957, Geology and ground-water resources of the lower South Platte River Valley between Hardin, Colorado, and Paxton, Nebraska, with a section on Chemical quality of the ground water, by H.A. Swenson: U.S. Geological Survey Water-Supply Paper 1378, 431 p.

Boettcher, A.J., 1966, Ground-water development in the High Plains of Colorado, with a section on Chemical quality of the ground water, by Robert Brennan: U.S. Geological Survey Water-Supply Paper 1819-I, 22 p.

Bradley, Edward, and Johnson, C.R., 1957, Geology and ground-water hydrology of the valleys of the Republican and Frenchman Rivers, Nebraska: U.S. Geological Survey Water-Supply Paper 1360-H, p. 589-713.

Cady, R.E., and Peckenpaugh, J.M., 1985, Documentation of a regional aquifer simulation model, RAQSIM, and a description of support programs applied in the Twin Platte-Middle Republican study area, Nebraska: U.S. Geological Survey Water-Resources Investigations Report 85-4168, $239 \mathrm{p}$.

Cardwell, W.D.E., 1953, Irrigation-well development in the Kansas River Basin of eastern Colorado: U.S. Geological Survey Circular 295, 72 p.

Cardwell, W.D.E., and Jenkins, E.D., 1963, Ground-water geology and pump irrigation in Frenchman Creek Basin above Palisade, Nebraska, with a section on The chemical quality of the water, by E.R. Jochens and R.A. Krieger: U.S. Geological Survey Water-Supply Paper 1577, 472 p.

Condra, G.E., 1907, Geology and water resources of the Republican River Valley and adjacent areas, Nebraska: U.S. Geological Survey Water-Supply Paper 216, 71 p.

Dugan, J.T., 1984, Hydrologic characteristics of Nebraska soils: U.S. Geological Survey Water-Supply Paper 2222, 19 p.

Eversoll, D.A., Dreeszen, V.H., Burchett, R.R., and Prichard, G.E., 1988, Bedrock geologic map showing the configuration of the bedrock surface, McCook $1^{\circ}$ $X 2^{\circ}$ quadrangle, Nebraska and Kansas, and part of the Sterling $1^{\circ} \times 2^{\circ}$ quadrangle, Nebraska and Colorado: U.S. Geological Survey Miscellaneous Investigations Map I-1878, 1 sheet, scale 1: 250,000.

Fenneman, N.M., 1931, Physiography of western United States: New York, McGraw-Hill, 534 p.

Goeke, J.W., Peckenpaugh, J.M., Cady, R.E., and Dugan, J.T., 1992, Hydrogeology of parts of the Twin Platte and Middle Republican Natural Resources Districts, southwestern Nebraska: Nebraska Water Survey Paper 70, 89 p.

Jensen, M.E., Robb, C.N., and Franzoy, C.E., 1970, Scheduling irrigations using climate-crop-soil data: Journal of Irrigation and Drainage Division, v. 96, no. IR 1, p. 25-37.

Johnson, A.I., 1967, Compilation of specific yield for various materials: U.S. Geological Survey WaterSupply Paper 1662-D, 74 p.

Johnson, C.R., 1960, Geology and ground water in the Platte-Republican Rivers watershed and the Little Blue River Basin above Angus, Nebraska, with a section on Chemical quality of the ground water, by Robert Brennan: U.S. Geological Survey Water-Supply Paper 1489, $142 \mathrm{p}$.

Kaul, B.K., and Rolfsmeier, S.B., 1993, Natural vegetation of Nebraska, in Flowerday, C.A., ed., Flat Water-A history of Nebraska and its water, 1993: University of Nebraska-Lincoln, Conservation and Survey Division, Institute of Agriculture and Natural Resources Resource Report 12, p. 163.

Lappala, E.G., 1976, Changes in the water supply in the Upper Republican Natural Resources District, southwest Nebraska, from 1952-75: U.S. Geological Survey Open-File Report 76-498, 17 p.

1978, Quantitative hydrogeology of the Upper Republican Natural Resources District, southwest Nebraska: U.S. Geological Survey Water-Resources Investigations Report 78-38, 200 p.

Lappala, E.G., Emery, P.A., and Otradovsky, F.J., 1979, Simulated changes in ground-water levels and streamflow resulting from future development (1970 to 2020) in the Platte River Basin, Nebraska: U.S. Geological Survey Water-Resources Investigations Report 79-26, 82 p.

Lawson, M.P., Dewey, K.F., and Neild, R.E., 1977, Climatic atlas of Nebraska: Lincoln. University of Nebraska Press, $88 \mathrm{p}$.

Leonard, G.J., and Huntoon, P.W., 1974, Groundwater geology of Southwest Nebraska Groundwater Conservation District: University of NebraskaLincoln, Institute of Agriculture and Natural Resources Water Survey Paper 37, $37 \mathrm{p}$.

Luckey, R.R., 1973, Digital model of the hydrologic system, northern High Plains of Colorado-A preliminary report: Colorado Water Conservation Board Water Resources Circular 19, 40 p. 
Luckey R.R., Gutentag, E.D., Heimes, F.J., and Weeks, J.B., 1986, Digital simulation of ground-water flow in the High Plains aquifer in parts of Colorado, Kansas, Nebraska, New Mexico, Oklahoma, South Dakota, Texas, and Wyoming: U.S. Geological Survey Professional Paper 1400-D, 57 p.

1988, Effects of future ground-water pumpage on the High Plains aquifer in parts of Colorado, Kansas, Nebraska, New Mexico, Oklahoma, South Dakota, Texas, and Wyoming: U.S. Geological Survey Professional Paper 1400-E, 44 p.

Luckey, R.R., and Hofstra, W.E., 1974, Digital model of the Ogallala aquifer in the northern part of the northern High Plains of Colorado: Colorado Water Conservation Board Water Resources Circular 24, 22 p.

McDonald, M.C., and Harbaugh, A.W., 1988, A modular three-dimensional finite-difference ground-water flow model: U.S. Geological Survey Techniques of WaterResources Investigations, book 6, chap. A1, 586 p.

National Oceanic and Atmospheric Administration, 195189 , Climatological data, annual summaries, Colorado and Nebraska: Asheville, North Carolina (published annually).

Nebraska Department of Agriculture, 1935-89, Nebraska agricultural statistics: Lincoln, Nebraska Department of Agriculture and U.S. Department of Agriculture Statistical Reporting Service.

Nebraska Department of Water Resources, 1935-89, Hydrographic reports (1955-89) and biennial reports (1935-54): Lincoln, Nebraska.

Peckenpaugh, J.M., and Dugan, J.T., 1983, Hydrogeology of parts of the Central Platte and Lower Loup Natural Resources Districts: U.S. Geological Survey WaterResources Investigations Report 83-4219, $100 \mathrm{p}$.

Peckenpaugh, J.M., Dugan, J.T., Kern, R.A., and Schroeder, W.J., 1987, Hydrogeology of the Tri-Basin and parts of the Lower Republican and Central Platte Natural Resources Districts, Nebraska: U.S. Geological Survey Water-Resources Investigations Report 87-4176, $117 \mathrm{p}$.

Pettijohn, R.A., and Chen, H.H, 1983a, Geohydrology of the High Plains aquifer system in Nebraska: U.S. Geological Survey Water-Resources Investigations, Open-File Report 82-502, 3 sheets, scale 1: 750,000. 1983b, Hydraulic conductivity, specific yield, and pumpage-_High Plains aquifer system, Nebraska: U.S. Geological Survey Water-Resources Investigations Report 82-4014, 3 sheets, scale 1:750,000.

Prudic, D.E., 1989, Documentation of a computer program to simulate stream-aquifer relations using a modular, finite-difference, ground-water flow model: U.S. Geological Survey Open-File Report 88-729, 113 p.

Redell, D.L., 1967, Distribution of ground-water recharge: Ft. Collins, Colorado State University, Agricultural Engineering Department technical report, 132 p.
Steele, E.K., 1988, Estimated use of water in Nebraska: University of Nebraska-Lincoln, Conservation and Survey Division, Nebraska Water Survey Paper 64, $125 \mathrm{p}$.

U.S. Bureau of Reclamation, 1974, Supplemental watersupply study, Frenchman-Cambridge Division, Nebraska: U.S. Bureau of Reclamation appraisal report, $25 \mathrm{p}$.

U.S. Department of Commerce, Bureau of the Census, 1989, Census of agriculture, 1987, County data (Nebraska): Washington, D.C., U.S. Government Printing Office.

U.S. Geological Survey, 1964, Compilation of records of surface waters of the United States, October 1950 to September 1960, part 6-B: U.S. Geological Survey Water-Supply Paper 1730, $514 \mathrm{p}$. 1969, Surface-water supply of the United States 196165, part 6, volume 3: U.S. Geological Survey WaterSupply Paper 1918, 751 p. 1973, Surface-water supply of the United States, 196670, part 6, volume 3: U.S. Geological Survey WaterSupply Paper 2118,710 p. 1971-75, Water resources data for Nebraska, 1970-74, part 1, U.S. Geological Survey Water-Data Reports (published annually).

1976-90, Water resources data for Nebraska, water years 1975-89: U.S. Geological Survey Water-Data Report NE-75-1 through NE-89-1 (published annually).

Waite, H.A., Reed, E.C., and Jones, D.S., Jr., 1946, Ground water in the Republican River Basin in Nebraska: Lincoln, Nebraska University, Conservation and Survey Division, Nebraska Water Resources Survey Water-Supply Paper 1, part 4, 38 p.

Waite, H.A., and others, 1948, Progress report on the ground-water hydrology of the Republican and Frenchman River Valleys, with a section on The chemical quality of the ground water, by H.A.

Swenson: U.S. Geological Survey Circular 19.83 p.

Weaver, J.E., and Albertson, F.W., 1956, Grasslands of the Great Plains: Lincoln, Nebr., Johnson Publishing Co., $395 \mathrm{p}$.

Weeks, J.B., Gutentag, E.D., Heimes, F.J., and Luckey, R.R., 1988, Summary of the High Plains regional aquifer-system analysis in parts of Colorado, Kansas, Nebraska, New Mexico, Oklahoma, South Dakota, Texas, and Wyoming: U.S. Geological Survey Professional Paper 1400-A, $30 \mathrm{p}$.

Wenzel, L.K., and Waite, H.A., 1941, Ground water in Keith County, Nebraska, with sections on Platte Valley Public Power and Irrigation District, Sutherland project, by E.E. Halmos, and Central Nebraska Public Power and Irrigation District, Tri-County project, by G.E. Johnson: U.S. Geological Survey Water-Supply Paper 848, $68 \mathrm{p}$. 